\title{
Scaling up a reproductive health curriculum in youth training courses
}

\author{
Laila Rahman \\ Population Council \\ M. Mazharul Islam \\ Ubaidur Rob \\ Population Council \\ Ismat Bhuiya \\ Population Council \\ M.E. Khan \\ Population Council
}

Follow this and additional works at: https://knowledgecommons.popcouncil.org/departments_sbsr-rh

Part of the Demography, Population, and Ecology Commons, International Public Health Commons, and the Public Health Education and Promotion Commons How does access to this work benefit you? Let us know!

\section{Recommended Citation}

Rahman, Laila, M. Mazharul Islam, Ubaidur Rob, Ismat Bhuiya, and M.E. Khan. 2006. "Scaling up a reproductive health curriculum in youth training courses," FRONTIERS Final Report. Washington, DC: Population Council. 


\title{
Scaling up a Reproductive Health Curriculum In Youth Training Courses
}

\author{
Laila Rahman \\ Population Council, Dhaka \\ Md. Rafiqul Islam \\ Department of Youth Development, Ministry of Youth and Sports \\ Government of the Peoples’ Republic of Bangladesh \\ Ubaidur Rob and Ismat Bhuiya \\ Population Council, Dhaka \\ M. E. Khan \\ Population Council, India
}

October 2006

This study was funded by the U.S. AGENCY FOR INTERNATIONAL DEVELOPMENT (USAID) under the terms of Cooperative Agreement number HRN-A-00-98-00012-00 and Population Council In-house Project No. 5800 53074. The opinions expressed herein are those of the authors and do not necessarily reflect the views of USAID.
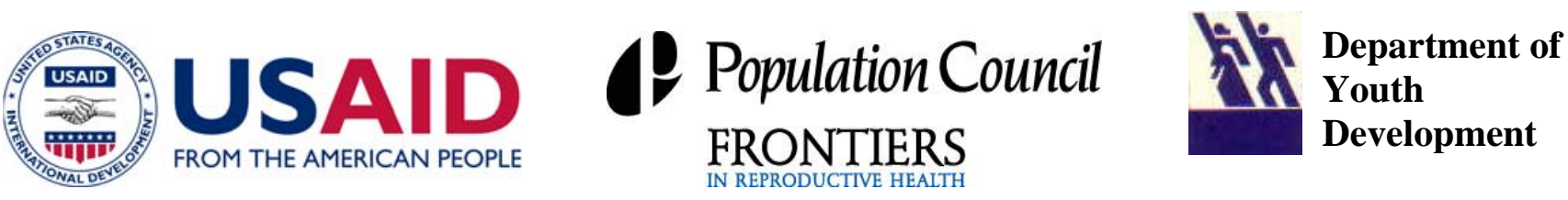


\section{EXECUTIVE SUMMARY}

Considering the reproductive health information and service needs of adolescents and youth, the Population Council's Frontiers in Reproductive Health (FRONTIERS) Program, in collaboration with the Ministry of Health and Family Welfare, the Urban Family Health Partnership, and two nongovernmental service delivery partners, carried out the Global Youth project in northwestern Bangladesh from 1999-2003. The study used a quasi-experimental design with pre-post measurements and two experimental strategies. Strategy I provided reproductive health education to out-of school adolescents linked with adolescent-friendly services at health facilities, while the Strategy II provided reproductive health education to both in- and out-of school adolescents linked with adolescent-friendly services (Bhuiya et al. 2004). Teachers and facilitators were trained to provide the reproductive health education to in-school and out-ofschool adolescents, respectively, and service providers were trained on rendering youth friendly services. The trained teachers imparted reproductive health education to students in grades eight and 11 in eight secondary schools (Bhuiya et al. 2004, 2003, 2002, 2001; Rob et al. 2002; Rob and Bhuiya 2001). An adolescent reproductive health curriculum was developed with the active participation of teachers, facilitators, and program managers. The contents of the curriculum were selected on the basis of findings from focus group discussions with teachers, parents, religious and community leaders (Bhuiya et al. 2004, 2003, 2002, 2001).

The important lesson learned from the Global Youth project was that reproductive health education could increase reproductive health knowledge in adolescents, particularly in areas related to reproductive biology, family planning, pregnancy, sexually transmitted infections (STIs), HIV and AIDS. The population based surveys further showed that contrary to common belief, reproductive health education does not increase sexual activity; instead it increases the use of condoms among sexually active youth (Bhuiya et al. 2004).

Government officials, school management committees, teachers, and parents strongly supported the project activities. Furthermore, parents suggested that schools should deliver such sensitive reproductive health messages, as they themselves were unable to do so. The study findings indicate that a formal reproductive health course is acceptable to community members and can easily be imparted through the regular school system. The Ministry of Health and Family Welfare, under the Global Fund to Fight AIDS, Tuberculosis and Malaria (GFATM), has utilized the innovative teacher model, the curriculum and materials from the project. In addition, Save the Children (UK), UNFPA, and several other nongovernmental organizations currently utilize the curriculum as a resource material.

Building on the experience of the Global Youth project, the Population Council worked with the Ministry of Youth and Sports from February 2004 to December 2005 to introduce reproductive health education into the various vocational training courses offered by the Department of Youth Development. The training is offered to males and females between 15 and 30 years of age in a variety of areas as training for self-employment. The Department operates 64 training centers at both district and sub-district levels, of which 47 are residential. At these residential training centers, enrollment is usually for three months with four batches of trainees per year.

The current project provided technical assistance to the Ministry and the Department of Youth Development to adapt the reproductive health curriculum developed under the Global Youth 
project and to introduce it as part of the regular vocational training course. Five residential youth training centers of the Department of Youth Development introduced the life skill-based reproductive health education in October-December 2004.

The major activities of the project included modification of the reproductive health curriculum, conducting training of trainers, organizing sensitization meetings with peer teachers, and implementing the reproductive health curriculum in the five selected training centers. The 10hour curriculum employed interactive and lively methods such as stories, quizzes, riddles, debates, visuals, and discussions. The teaching aides included transparencies and overhead projectors, story leafs, white boards and markers, banners, question boxes, and compact discs (CDs).

In order to measure the effectiveness of the curriculum, the study administered a pre- and two post-test surveys among the students attending the training courses. Data from the surveys of students on knowledge, attitudes, and skills were analyzed by gender and age. Qualitative data included both focus group discussions and in-depth interviews with students and officials of Department of Youth Development.

Findings from pre- and post-test results indicate significant positive changes in reproductive health knowledge, attitudes, and life skills among the youth:

- Knowledge about physical changes occurring during adolescence increased from 64 percent at the pre-test (before the curriculum was introduced) to over 95 percent at the post-test. Knowledge about the fertile period, the time of the month a woman is most likely to get pregnant if she has sexual relations, increased significantly, almost doubling at the post-test. Knowledge about the IUD and implants increased from 30 percent at the pre-test to 95 percent at the post-test. Knowledge about the dual role of condoms - that they provide protection from both pregnancy and sexually transmitted infections-increased significantly to from 65 percent at the pre-test to 89 percent at the post-test. The percentage of students who had heard about emergency contraceptive pills (ECP) increased from 42 to 93 percent, and two-thirds could mention the reasons for use of ECP at the post-test compared to less than 20 percent at the pre-test.

- Misunderstanding about the role of the mother in determining the sex of a child was substantially dispelled-awareness that only the male determines the sex of a child rose from 26 percent at the pre-test to 76 percent at the post-test. Misconceptions about routes of sexually transmitted infections decreased by over 30 percent, and the awareness about continuing medication even when the symptoms of a disease disappear doubled to 80 percent. Knowledge about ways to prevent HIV also increased, notably negotiation on safe sex, which increased from 53 at the pre-test to 83 percent at the post-test.

- Post-test results also showed almost a doubling in the percentage of youth who do not consider menstruation as a disease (58 to 93\%), and almost a three-fold increase in the percentage who agreed that menstrual cloths should be dried in direct sunlight (33 to 94\%).

- Results from the pre- and post-tests revealed that knowledge of life skills also improved, including how to avoid pre-marital sex, averting peer pressure to visit commercial sex workers, and ignoring media influence for substance abuse. 
The study findings confirmed that participatory education increases reproductive health knowledge, life skills, and positively changes the attitudes of the youth. Results also revealed that training of trainers and training materials, especially the transparencies, curriculum, and question boxes, enabled teachers to effectively impart reproductive health education. Over 95 percent of students reported that teachers had sufficient knowledge of the topic, explained the subject matter clearly, and discussed the role of condoms. Only one-tenth of students reported that the teachers were judgmental and unfriendly.

Based on the success of the project, the remaining 42 residential youth centers introduced the reproductive health course beginning in October 2005.

The study recommends further scaling up of this tested curriculum to other non-residential training centers of the Department of Youth Development in order to ensure maximum utilization of limited resources. However, prior to scaling up the reproductive health curriculum, the following recommendations are made: 1) increase the length of the training of trainers from five to six days; 2) extend the duration of the curriculum from 10 to 12 hours; 3 ) link the training institutions with the health facilities and other support organizations that work in the area of violence against women and substance abuse; 4) provide follow-up support to teachers and regular monitoring visits; and 5) provide copies of the reading materials to each student to accurately diffuse reproductive health knowledge among the neighborhood youth. 


\section{CONTENTS}

Executive Summary

List of Tables, Boxes and Figures.....

Abbreviations .

Acknowledgements

Introduction .1

Why introduce reproductive health curriculum in vocational training courses ..................2

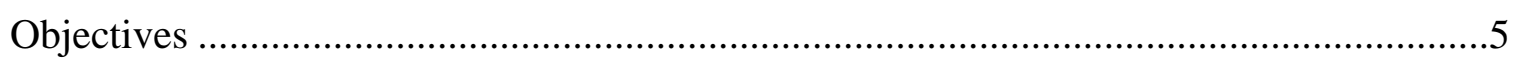

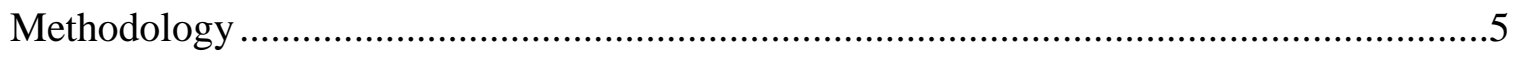

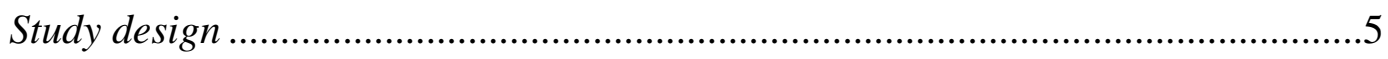

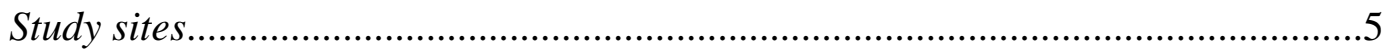

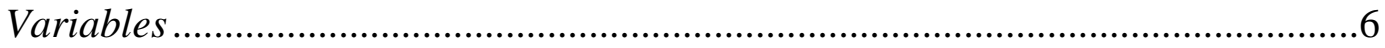

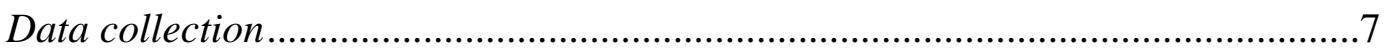

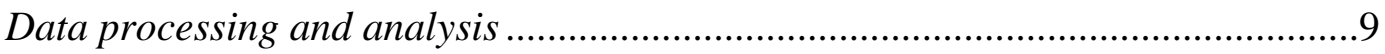

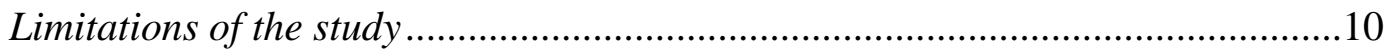

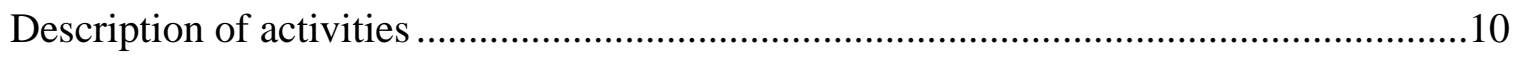

Adaptation of the reproductive health curriculum..............................................10

Training of trainers ..........................................................................................13

Conducting sensitization meetings with peer teachers ........................................15

Implementation of the reproductive health curriculum .........................................15

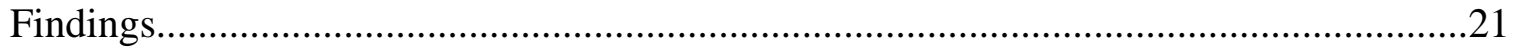

Socio-demographic characteristics of students ................................................21

Knowledge of reproductive health issues ..........................................................24

Attitudes towards reproductive health issues ......................................................27

Reproductive health life skills ........................................................................29

Reproductive health education in training courses ..............................................31

Obstacles faced and strategies to overcome the barriers ....................................36

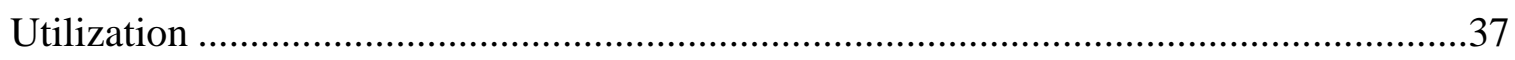

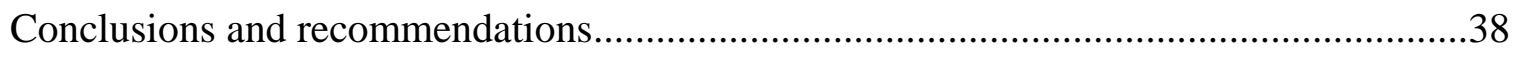

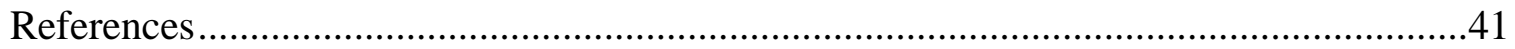

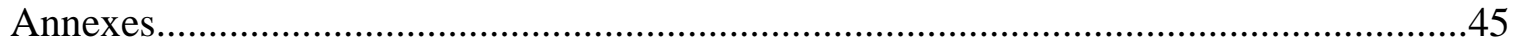




\section{LIST OF TABLES}

Table 1 Distribution of students attending pre- and post-test surveys by sex and training centers.....

Table 2 Distribution of questions deposited in question boxes of the five Youth Training Centers.

Table 3 Distribution of students who attended reproductive health sessions by training centers

Table $4 \quad$ Average attendance rates in reproductive health sessions by sex and training centers

Table 5 Background characteristics of students

Table 6 Background characteristics of students who attended the final post-test survey and those who did not.....

Table 7 Percent distribution of students' correct knowledge about sex determinant of a child and pregnancy-related danger signs by sex and time of survey.....

Table 8 Percent distribution of students' correct knowledge about prevention of HIV by age, sex and time of survey

Table 9 Distribution of teachers according to selected topics

Table 10 Strengths and weaknesses of the teachers identified during the TOT

Table 11 Strengths and weaknesses of the teachers from the students' perspective. 35

Table 12 Obstacles faced and strategies to overcome the barriers of reproductive health education 36

Table A.1 Number of students by sex and training centers 45

Table A.2 Number of students who attended reproductive health sessions by sex and training centers

Table A.3 Percent distribution of students' correct reproductive health knowledge by age, sex and time of survey

Table A.4 Percent distribution of students' correct knowledge of fertile period, modern contraceptive methods, condoms, and ECP by age, sex and time of survey ..... 47 
Table A.5 Percent distribution of students' correct knowledge about sex determinant of a child and pregnancy-related danger signs by age, sex and time of survey

Table A.6 Percent distribution of students' correct knowledge of transmission of STIs by age, sex and time of survey

Table A.7 Percent distribution of students' correct knowledge of what to do to treat STIs by age, sex and time of survey

Table A.8 Percent distribution of students' correct knowledge about prevention of HIV by age, sex and time of survey 51

Table A.9 Percent distribution of students' positive attitudes towards wet dreams, masturbation, and menstruation by age, sex and time of survey

Table A.10 Percent distribution of students' attitudes towards use of condoms and family planning methods by age, sex and time of survey

Table A.11 Percent distribution of students who stated what to do in case an elderly person touches a young person inappropriately by sex and time of survey....... 53

Table A.12 Percent distribution of students who stated what to do in case a boyfriend wants to initiate sex by time of surveys and sex ................................................ 53

Table A.13 Percent distribution of students' critical thinking skills to avert media influence and peer pressure by age, sex and time of survey .....

Table A.14 Percent distribution of students' attitudes towards reproductive health education by age, sex and time of survey

Table A.15 Average mark of obtained by teachers in imparting reproductive health education in the practice sessions of training of trainers 55

Table A.16 Percent distribution of students who stated specific capacities of teachers in imparting reproductive health education by sex and time of survey 


\section{LIST OF BOXES}

Box $1 \quad$ Facilitation criteria …………………….................................................... 14

Box 2 Reproductive health session training materials.................................................. 16

Box $3 \quad$ Reading materials....................................................................................... 17

Box $4 \quad$ Decision to quit smoking ……………….................................................. 17

Box 5 Interest in attending reproductive health sessions............................................. 19

Box $6 \quad$ The action oriented training of trainers ............................................................ 32

\section{LIST OF FIGURES}

Figure 1 Banner depicting the reproductive health course goal, objectives and topics.... 12

Figure 2 Percent distribution of students who attended specific reproductive health sessions

Figure 3 Percent distribution of students who knew that HIV cannot be detected by a person's appearance by sex and time of surveys

Figure 4 Percent distribution of students on belief and perception towards wet dreams/ejaculation, masturbation, menstruation and menstrual hygiene.

Figure 5 Percent distribution of students on decisionmaking skill in case of sexual abuse (multiple responses)

Figure 6 Percent distribution of students on negotiation skills in case a boyfriend wants to initiate sex

Figure 7 Percent distribution of students on critical thinking skills to avert media influence and peer pressures

Figure 8 Teachers' capacity in delivering reproductive health education during practice sessions of the training of trainers

Figure 9 Teachers' ability to conduct reproductive health sessions as reported by students in the post-test 35 


\section{ABBREVIATIONS}

\begin{tabular}{|c|c|}
\hline AIDS & Acquired Immune Deficiency Syndrome \\
\hline $\mathrm{ARH}$ & Adolescent Reproductive Health \\
\hline BCC & Behavior Change Communication \\
\hline BCCP & Bangladesh Center for Communications Program \\
\hline $\mathrm{CD}$ & Compact Disc \\
\hline CNN & Condoms, Needles and Negotiation skills \\
\hline CSW & Commercial Sex Worker \\
\hline DGFP & Directorate General of Family Planning \\
\hline DYD & Department of Youth Development \\
\hline GFATM & Global Fund to Fight AIDS, Tuberculosis and Malaria \\
\hline HIV & Human Immunodeficiency Virus \\
\hline IUD & Intrauterine Device \\
\hline NGO & Nongovernmental Organization \\
\hline PSTC & Population Services and Training Center \\
\hline $\mathrm{RH}$ & Reproductive Health \\
\hline RTI & Reproductive Tract Infection \\
\hline STI & Sexually Transmitted Infection \\
\hline TOT & Training of Trainers \\
\hline UFHP & Urban Family Health Partnership \\
\hline USAID & United States Agency for International Development \\
\hline UNICEF & United Nations Children’s Fund \\
\hline UNFPA & United Nations Population Fund \\
\hline
\end{tabular}


WHO World Health Organization

YTC Youth Training Center 


\section{ACKNOWLEDGEMENTS}

We are highly indebted to USAID for generously sponsoring the project. We are thankful to Ms. Shawn Malarcher, Technical Advisor of USAID/GH/PRH/RTU for visiting a project site, which encouraged trainers and the youth.

We sincerely appreciate Mr. Syed Shujauddin Ahmed, Secretary In-charge, Ministry of Youth and Sports, Government of the People’s Republic of Bangladesh, for inaugurating the dissemination seminar. We are grateful to Mr. S. M. Waliur Rahman, Director General of the Department of Youth Development, for his leadership and guidance in successfully implementing the curriculum in youth training courses.

We would also like to extend our heartfelt thanks to the dedicated officials of the Department of Youth Development—Ms. Rukshana Yeasmin, Mr. Md. Mahbubur Rahman, Mr. Md. Sirajul Islam, Mr. Md. Shafiqul Islam, Ms. Sabrina Akhtar Bethi, Ms. Tahmida Rahman, Mr. Md. Quamruzzaman Akanda, Ms. Jahanara Faruqui, Mr. Faruk Ahmed Rouf, Mr. Md. Iqbal Hossain, and Mr. Raju Ahmed. For extending cooperation, we are also thankful to Mr. Rajat Pal Chowdhury, Mr. Md. Mujibar Rahman, Mr. Md. Abul Hashem, Mr. Mizanur Rahman, Mr. A. N. Maksudur Rahman, and Ms. Tania Zaman. Our special thanks to the hundreds of participating students - without their enthusiastic and active participation in self-administered surveys and reproductive health education sessions the study could not have been accomplished.

Mr. Md. Mosharraf Hossain, Director, and Mr. Md. Humayun Khaled, Deputy Secretary, Ministry of Youth and Sports, deserve special thanks for expert moderation and chairing of sessions, respectively. We are thankful to the Directors of the Department of Youth Development, namely, Mr. Zillur Rahman, Mr. K. M. Amanur Rahman, Mr. Ramani Mohan Chakma, Mr. Ratan Chandra Bhowmik, and Mr. Khondaker Matiar Rahman for their contributions during the discussion session. We are also thankful to the group facilitators, Mr. Md. Sayeduzzaman Pathan, Mr. Md. Rabiul Alam, and Mr. Md. Rafiqul Islam, and the rapporteurs, Mr. Md. Zakir Hossain Akanda, Senior Assistant Chief, Ministry of Youth and Sports, and Mr. Mukitul Islam, Principal, Central Human Resource Development Center.

We acknowledge Population Services and Training Center for proficiently imparting the training of trainers, and Associates for Community and Population Research for efficient management of data. We are grateful to Dr. Noor Mohammad, National Program Officer, Youth and Education of UNFPA, for his support and cooperation throughout the project period. 


\section{INTRODUCTION}

Youth 10 to 24 years old constitute about one-third of the population of Bangladesh. In the transition from childhood to adulthood, this cohort lacks information or has misinformation about reproductive health and sexuality which makes them vulnerable to high risk behaviors and related outcomes, including substance abuse, unintended pregnancy, sexually transmitted infections (STIs), HIV, sexual abuse, and violence. To enable young people to improve their reproductive health status, it is crucial that they receive correct and adequate sexual and reproductive health information so that they can effectively avert risky behaviors and meet the challenges of everyday life. In addition to information, life skills are particularly important. As defined by the World Health Organization (WHO), life skills are abilities for adaptive and positive behavior that enable individuals to deal effectively with the demands and challenges of everyday life (WHO 2003). Life skills have an effect on the ability of young people to protect themselves from health threats, build competencies to adapt positive behaviors, and foster healthy relationships.

Studies on reproductive health education from all over the world, including Bangladesh, indicate that reproductive health education is likely to bring positive changes in young people's reproductive health behavior and utilization of health services, contrary to the common belief that provision of such information would make them promiscuous (Bhuiya et al. 2004). The encouraging findings of the 1999 Global Youth project conducted under the Population Council in Bangladesh led to utilization of the innovative school-based model and the accompanying adolescent reproductive health curriculum by the Ministry of Health and Family Welfare under the Global Fund to Fight AIDS, Tuberculosis and Malaria (GFATM). The model replaces the nongovernmental organization (NGO) workers with teachers in providing reproductive health education to school students, which was earlier believed to be ineffective. UNFPA, Save the Children UK, and several other NGOs have also used the adolescent reproductive health curriculum as a resource material. In addition, the GFATM-supported activities used the Global Youth project curriculum as one of the base materials in developing the HIV and AIDS curriculum for young people (Bhuiya et al. 2004).

Under the Ministry of Youth and Sports, the Department of Youth Development provides training for self-employment of thousands of young people who are already in or about to join the labor force. Building on the experience of the Global Youth project, the Population Council worked with the Ministry of Youth and Sports to introduce reproductive health education into vocational training courses offered by the Department of Youth Development. The training is offered to males and females between 15 and 30 years of age in a variety of areas as training for self-employment. The Department operates 64 training centers at both district and sub-district levels, of which 47 are residential. At these residential training centers, enrollment is usually three months with four batches of trainees per year.

The Population Council provided technical assistance for the Department of Youth Development to adapt and introduce the life skill-based reproductive health education in five of its 47 residential youth training centers as part of the regular vocational training course. The duration of this technical assistance project was 23 months, from February 2004 to December 2005. This 
report summarizes the findings and lessons learned from the introduction of the reproductive health curriculum in youth training courses.

\section{WHY INTRODUCE REPRODUCTIVE HEALTH CURRICULUM IN VOCATIONAL TRAINING COURSES}

There is no formal reproductive health education for adolescents and youth in Bangladesh. This is due to the socio-cultural attitudes that do not encourage unmarried youth to learn about reproduction, while married adolescents are considered adults. Thus, many adolescents have no information or have misinformation about the physical and mental changes associated with puberty, sexuality, contraception, STIs, or HIV (Bhuiya et al. 2004, 2003, 2002, 2001; Barkat et al. 2000; Kabir 1999; Nahar et al. 1999). As a consequence, adolescents do not know how to protect themselves from unsafe sexual encounters, violence, and substance abuse. In addition to the lack of correct information, inquisitiveness, peer pressure, and economic constraints contribute to the exposure of youth to risks of various reproductive health problems.

In general, adolescent boys are exposed to substance abuse and STIs while girls face the risk of unintended pregnancy, violence, physical and sexual abuse (Bhuiya et al. 2002; Rahman, Bhuiya, and Rob 2003). Psychosexual problems relating to nocturnal emission, masturbation, and sexual ability also remain a concern for older boys who often feel guilty and ashamed, and many think masturbation is an illness (Kabir 2002). Sexual fantasies and masturbation are widespread among adolescent boys, despite the guilt and fear of negative health consequences caused by masturbation (Barkat et al. 2000; Kabir 2002). Similarly, adolescent girls are not knowledgeable about menstrual management and hold many misconceptions on menstrual blood, clothes, and food (Barkat et al. 2000; Kabir 1999; Nahar et al. 1999).

Though Bangladesh is a conservative society, premarital sex is not uncommon, especially among boys (Bhuiya et al. 2004, 2003, 2002, 2001; Rob et al. 2002; Haider et al. 1997). In rural areas, limited contact with girls also leads to sexual activity among boys, which is sometimes consensual and sometimes abusive (Kabir 2002). In urban areas, out-of-school boys initiate sex following their elders and also to accompany friends (Bhuiya et al. 2004, Rahman, Bhuiya, and Rob 2003). These young boys tend not to use condoms due to lack of comfort, inadequate selfperception of risk, and the apprehension of getting teased by friends (Rahman, Bhuiya, and Rob 2003). The inaccessibility of youth-friendly services remains an issue for youth (Bhuiya et al. 2004; Rob et al. 2002). Adolescent girls are likely to engage in sex out of fear of desertion by their boyfriends or through sexual abuse (Rahman, Bhuiya, and Rob 2003). Adolescents are also engaged in buying and selling sex-42 percent of customers of commercial sex workers based in brothels are reported to be students, and the average age of street- and hotel-based sex workers is less than 21 years of age (Baatsen 2003).

Alarmingly, more than one-third of girls 15 to 19 years old are married (Bangladesh Bureau of Educational Information and Statistics 2003). These adolescent girls are forced into marriages, often without their consent and with much older counterparts (Amin, Mahmud, and Huq 2002). Consequently, married adolescent girls have little say about family planning or the timing and terms of sexual intercourse with their husbands, and are under pressure from family to prove their fertility by having children as soon as possible (Rob and Piet-Pelon 2001). As a result, 
Bangladeshi women have a pattern of early childbearing. Young women's fertility is high with 135 births per 1,000 women in the 15-19 age group (NIPORT, Mitra and Associates, and Macro International 2004). The current use of any contraceptive method is 29 percent among married adolescent girls, compared with the national contraceptive prevalence rate of 58 percent for all women of reproductive age (NIPORT, Mitra and Associates and Macro International 2004). Adolescent fertility continues to contribute to the population momentum. Early marriage leads to multiple reproductive health problems and potentially severe consequences, including maternal death. It is reported that adolescents and young married girls contribute to approximately 40 percent of maternal deaths (NIPORT and ORC Macro 2003).

In view of the sheer number of youth, their vulnerability to reproductive health problems, as well as their contribution to population momentum, the Government of Bangladesh has been taking steps to address the information and service needs of youth. The Health and Population Sector Program identified adolescents as an underserved priority target group (Ministry of Health and Family Welfare 2003; 1998). The Youth Policy also underlined the need to provide reproductive health information to youth and to make them aware about HIV and AIDS, sexually transmitted diseases, and adverse effects of narcotics (Ministry of Youth and Sports 2004). Likewise, the proposed Population Policy of Bangladesh recognizes the need for reproductive health education and outlines the role of different government agencies in imparting reproductive health education (Ministry of Health and Family Welfare 2002). The Ministry of Youth and Sports was also encouraged to implement reproductive health and population-related development programs for youth.

This project builds upon the 1999 Global Youth project, an operations research study implemented by the Population Council in the northwestern part of Bangladesh to improve the reproductive health of adolescents (Bhuiya et al. 2004). The study used a quasi-experimental design with pre-post measurements and two experimental strategies. Strategy I provided reproductive health education to out-of school adolescents linked with adolescent-friendly services at health facilities, while the Strategy II provided reproductive health education to both in-school and out-of-school adolescents linked with adolescent-friendly services (Bhuiya et al. 2004). Teachers and facilitators were trained to provide the reproductive health education to inschool and out-of-school adolescents, respectively, and service providers were trained on providing youth-friendly services. The trained teachers imparted reproductive health education to students in grades eight and 11 in eight secondary schools (Bhuiya et al. 2004, 2003, 2002, 2001; Rob et al. 2002; Rob and Bhuiya 2001). An adolescent reproductive health curriculum was developed with active participation of teachers, facilitators, and program managers. The contents of the curriculum were selected on the basis of the findings of focus group discussions with teachers, parents, religious and community leaders (Bhuiya et al. 2004, 2003, 2002, 2001).

The important lesson learned from the Global Youth project study was that reproductive health education could increase reproductive health knowledge in adolescents, particularly in areas related to reproductive biology, family planning, pregnancy, STIs, HIV and AIDS. The population-based surveys further showed that contrary to common belief, reproductive health education does not increase sexual activity; instead it increases the use of condoms among sexually active youth (Bhuiya et al. 2004). Thus the findings indicated that the reproductive health education is likely to bring positive changes in young people's reproductive health 
behavior and utilization of health facilities, contrary to the common belief that it would make them promiscuous (Bhuiya et al. 2004).

Building on the experience of the Global Youth project, the Population Council worked with the Ministry of Youth and Sports to introduce reproductive health education into the vocational training courses offered by the Department of Youth Development. From 1981 through 2003, the Department of Youth Development trained more than two million youth, half of whom are selfemployed (Department of Youth Development 2003). The Department has 295 training centers located at the district and sub-district levels to provide residential and non-residential vocational training courses to about one hundred thousand youth annually. Training courses include agrobased subjects such as livestock, poultry and fisheries as well as technical courses in areas such as computers, electronics, secretarial science, batik, and dressmaking. The duration of the training courses varies from one month to six months. The Department of Youth Development also offers short-term courses on different trades at the sub-district level.

The Youth Training Centers are the only residential training institutions of Department of Youth Development that offer a three-month integrated course on livestock, poultry, fisheries and agriculture on a regular basis. The Youth Training Centers are located in 47 districts, and each center conducts four batches of training per year. In each batch, approximately 100 students are enrolled, with a male female ratio of 70:30. The current project provided technical assistance to the Department of Youth Development to adapt the reproductive health curriculum and introduce it as part of the regular vocational training courses in five of its residential Youth Training Centers.

Per the Youth Policy of the Government of Bangladesh, the Department of Youth Development considers persons 18 to 35 years old as youth who are eligible to receive training. However, most of the students of the Youth Training Centers are between 18 and 24 years of age. A Coordinator or Deputy Program Coordinator manages each center, while the Senior Instructors conduct theoretical sessions. In addition, one Community Development Officer is responsible for the youth development subject that encompasses topics such as leadership, formation of groups and youth clubs, gender, HIV prevention, and motivational issues. However, being a part of the traditional society, under the conventional teacher-student relationship, the Community Development Officers were not comfortable in teaching sessions on HIV prevention to young people. Nor did they have the training or materials to conduct the training.

The lessons learned from the Global Youth project in Bangladesh indicated that teachers could impart training on reproductive health issues to young people if they are trained and equipped with adequate behavior change communication materials, including an interactive and lively curriculum that employs participatory and pedagogical methods (Bhuiya et al. 2004, 2002). Therefore, these vocational youth training centers were considered to have potential constituencies where the reproductive health curriculum developed and tested under the Global Youth study could be scaled up. In addition to the Department of Youth Development training institutions, there are 1,562 vocational and technical training institutions that train more than 130,000 students per year (Bangladesh Bureau of Educational Information and Statistics 2003). If successful, the introduction of the reproductive health curriculum in the Department of Youth Development's Youth Training Centers would significantly improve the chance of further scaling up of the reproductive health education in these vocational and technical institutions. 


\section{OBJECTIVES}

The objective of this technical assistance project was to introduce the reproductive health curriculum developed under the Global Youth project of the Population Council as a part of the regular vocational training courses of the Department of Youth Development's Youth Training Centers. Specific objectives were to:

- Equip and train the teaching staff of the Department of Youth Development training institutions to enable them to provide reproductive health education to the trainees.

- Improve the level of knowledge, attitudes, and skills on reproductive health issues of youth attending the Department of Youth Development training courses.

- Disseminate the lessons learned from the project.

- Build on the experiences of the project and advocate for the introduction of reproductive health education to other vocational institutions.

\section{METHODOLOGY}

\section{Study design}

To measure the effectiveness of the reproductive health curriculum, a pre- and post-design was used. The study was carried out in five selected Youth Training Centers. All students who were enrolled and present on the day of the test in the selected centers were included in the pre-test. The evaluation consisted of two post-tests, one immediately after the last reproductive health education session was conducted, and the other one month later in order to measure the retention of knowledge. The same self-administered questionnaire was used in all three tests, with additional questions on the socio-demographic background included on the pre-test. Only those students who participated in the pre-test and attended reproductive health education sessions were included in the post-tests.

The study was conducted in three phases. In the preparatory phase, the partnership with the Department of Youth Development was formed, and sites and teachers were selected. The curriculum developed under the Global Youth project was reviewed and modified to suit the Youth Training Center context. The intervention phase included the training of trainers, sensitization meetings with the peer teachers, and implementation of the reproductive health curriculum in the selected centers. The evaluation phase consisted of pre- and post-test surveys, in-depth interviews and focus group discussions, data analysis, report writing, and dissemination of the study findings.

\section{Study sites}

The Department of Youth Development, considering the physical condition of the roads, ease of communication, and geographical proximity with Dhaka, purposively selected the study sites. The five sites included Brahmanbaria, Hobiganj, Kishoreganj, Naogaon, and Savar. Two of the Youth Training Centers were located in Dhaka division, while others were in Comilla, Sylhet 
and Rajshahi divisions. Savar is the oldest center, which is managed by a Coordinator and a Deputy Coordinator. The center at Savar also enrolls two hundred students per quarter while the other Youth Training Centers train only one hundred students per quarter. Though training centers are located in particular districts, students from other districts can be admitted to any of the Youth Training Centers. The training centers are built on approximately three acres of land and have one administrative building, one officer's quarters, and two dormitories, one for female and one for male students.

\section{Variables}

The independent variable in the study was the reproductive health course that was introduced, while the dependent variables were the reproductive health knowledge, attitudes, and skills of the youth. Process variables to measure the teachers' capability in imparting reproductive health education were also collected. The lists of dependent and process variables are given below.

\section{Reproductive health knowledge}

Trainees know about/that:

- Three major pubertal changes in girls and boys

- Fertile period for girls

- Four modern family planning methods

- Reason for use of emergency contraception

- Only the chromosome of the father determines the sex of a child

- Five danger signs during pregnancy, delivery, and after delivery

- Dual role of condoms (protection against both pregnancy and sexually transmitted infections or STIs)

- Four routes of transmission and three routes of non-transmission of STIs

- Three things to do and two things not to do in case one suffers from STIs

- Ways to prevent HIV

- The status of an HIV-infected person cannot be determined by his/her appearance

\section{Reproductive health attitudes}

Trainees agree that:

- It is natural for boys to have wet dreams/ejaculation

- Masturbation is not a bad habit

- Menstruation is not a disease, and menstrual cloths should be dried in direct sunlight

- Sexually active youth should use family planning methods to prevent pregnancy

- Sexually active youth should use condoms to prevent STIs and HIV

- Adolescents and youth should receive reproductive health, HIV, and gender education

- Trainees would advocate for reproductive health education 


\section{Reproductive health skills}

Trainees possess:

- Decisionmaking skills in case of sexual abuse

- Negotiation skills when a boyfriend wants to initiate sex

- Critical thinking skills to avert media and peer pressure about smoking, drugs, and visits to commercial sex workers

\section{Reproductive health education (process variables)}

Trainees believe that:

- Teachers had sufficient knowledge to impart reproductive health education

- Teachers could explain contents of the curriculum clearly

- Teachers explained the role of condoms to prevent STIs and HIV

- Teachers were friendly and non-judgmental

\section{Data collection}

One pre-test and two post-test surveys were conducted among the students by using selfadministered questionnaires. Out of 496 students enrolled in the five Youth Training Centers, 450 students participated in the pre-test in October 2004. Approximately 10 percent of the students were absent on the test days. Hence they were excluded from the post-test surveys. Immediate and final post-tests were conducted in November and December 2004 (Table 1). Note that female students represented only about 10 percent of respondents at each data collection moment. Insights on the dynamics of participants were provided by focus groups and in-depth interviews with students and informal discussions with trainers and officials of the Department of Youth Development.

The immediate post-test took place on the next academic day following the tenth and review sessions, provided that no other center held a test on that day. This enabled Population Council staff to be present during the administration of the questionnaires to ensure proper data collection. The final post-test was conducted one month later. Due to dropouts and emergency leave, about 13 percent of the students who attended the pre-test were absent in post-tests. 
Table 1. Distribution of students attending pre- and post-test surveys by sex and training centers

\begin{tabular}{|l|l|l|l|l|l|l|l|l|l|}
\hline \multirow{2}{*}{$\begin{array}{l}\text { Youth } \\
\text { Training } \\
\text { Centers }\end{array}$} & \multicolumn{3}{|l|}{$\begin{array}{l}\text { Number attending } \\
\text { pre-test survey }\end{array}$} & \multicolumn{3}{|l|}{$\begin{array}{l}\text { Number attending } \\
\text { immediate post-test } \\
\text { survey }\end{array}$} & \multicolumn{4}{l|}{$\begin{array}{l}\text { Number attending final } \\
\text { post-test survey }\end{array}$} \\
\cline { 2 - 11 } & Female & Male & Total & Female & Male & Total & Female & Male & Total \\
\hline Brahmanbaria & 10 & 65 & 75 & 9 & 53 & 62 & 9 & 54 & 63 \\
\hline Hobiganj & 8 & 34 & 42 & 8 & 25 & 33 & 8 & 27 & 35 \\
\hline Kishoreganj & 9 & 72 & 81 & 7 & 60 & 67 & 9 & 58 & 67 \\
\hline Naogaon & 5 & 85 & 90 & 5 & 76 & 81 & 5 & 73 & 78 \\
\hline Savar & 8 & 154 & 162 & 7 & 147 & 154 & 8 & 137 & 145 \\
\hline Total & $\mathbf{4 0}$ & $\mathbf{4 1 0}$ & $\mathbf{4 5 0}$ & $\mathbf{3 6}$ & $\mathbf{3 6 1}$ & $\mathbf{3 9 7}$ & $\mathbf{3 9}$ & $\mathbf{3 4 9}$ & $\mathbf{3 8 8}$ \\
\hline
\end{tabular}

Before conducting the pre-test, informed consent was obtained from the students. Authorization to attend the reproductive health education sessions as well as post-tests was collected at the same time. Instead of name and class roll number, a unique identification number known as Survey Registration Number (SRN), known only to the respondents, was used to ensure the highest level of confidentiality. Population Council staff prepared the SRN cards, each of which had a unique four-digit identification number. On the day of the survey, an SRN card in an envelope was distributed to each of the respondents at random. After carefully writing the designated number on her/his questionnaire, the student put the card back in the envelope, and marked the envelope with her/his class roll number. Then the envelopes were collected and kept in a sealed folder, which was opened again during the immediate post-test in front of the respondents. The same procedures were followed at the final post-test, however the envelopes were not taken back. Thus, the full confidentiality of the respondents was maintained.

Apart from the pre- and post-tests, qualitative data were also collected to complement the survey findings:

- Five focus group discussions in which a total of 102 students (26 females and 76 males) participated. The number of participants varied from 17 to 24 per group. Through the focus group discussions, attempts were made to get insights about student experiences, especially with the curriculum, teaching aids, and teachers. During discussions, students also offered suggestions on the curriculum and improvement for future reproductive health sessions. 
- Thirty in-depth interviews with students (10 females and 20 males) to learn about the usefulness of the reproductive health education and specific changes that participants may have made in their life based on the sessions. The female students were also asked whether or not they faced problems in attending sessions with the male students and teachers.

- Ten informal discussions with trainers and officials of the Department of Youth Development (4 females and 6 males) to learn about the challenges they faced and the strategies they used to overcome them while implementing the reproductive health sessions. Their opinions were also sought on the sustainability of the program and prospects for scaling up the reproductive health curriculum to other institutions.

Pre- and post-tests were also conducted among the 10 instructors/officials of the five Youth Training Centers who were trained as trainers. The participants were asked about knowledge on reproductive health issues and their attitudes and comfort in teaching the reproductive health sessions. In addition during the training of trainers, two days of practice sessions were held, and both participants and facilitators filled in a total of 116 facilitation observation checklists to measure the knowledge and skills of the trainees (see Annex C).

The teachers recorded reproductive health class attendance and at the end of each session, and they documented in a notebook the problems faced and strategies employed to overcome the challenges. Population Council staff monitored at least one reproductive health session per training center and provided feedback to the teachers. The checklist that was used to monitor the practice sessions was also used to monitor the sessions at the Youth Training Centers.

\section{Data processing and analysis}

The quantitative data from the pre- and post-test were doubly entered to minimize errors. Bivariate analysis was conducted to compare the findings in between the pre- and two post-tests. Knowledge, attitudes, and skills variables were analyzed by gender, age group, and time of tests. Statistical tests (z-tests) were performed to examine the difference between the proportions.

Qualitative analysis was done manually, and the information was used to understand: how the students felt about the acceptability and adequacy of the reproductive health materials in addressing their needs and concerns; whether the level of learning was sufficient from their perspective and from the perspective of the Department of Youth Development; what challenges were faced in implementing the curriculum and materials; what the strengths and limitations were; and how these had been addressed. Qualitative data were also used to understand: whether the teachers covered the full curriculum or if they were selective in choosing the content of the course; how students were exposed to or selectively excluded from key elements of the curriculum; and what factors of self-selection were operating at the student, teacher, and institution levels. Lastly, interviews and discussions with the Department of Youth Development officials were analyzed to understand the planning and budgeting processes within the department that could facilitate sustainability of this training or identify potential barriers to the 
adoption of this curriculum by the remaining training centers, pending positive results of the evaluation.

\section{Limitations of the study}

The study adopted a pre- and post-design, without a control group. The inherent problem of this design is that it becomes difficult to discern if the positive changes are due to learning in the classroom or simply natural maturation and social learning that occurs commonly in school settings. However, as the training centers were residential, it is assumed that the changes were due to the reproductive health education. Secondly, all the students who attended the pre-test did not attend both the post-tests. The absent rates were 12 percent and 14 percent for immediate and final post-tests, respectively. Not all students attended each of the reproductive health classes; attendance rates ranged between 67 and 89 percent. Review sessions were carried out to offset missed classes and reinforce the lessons. Finally, the two post-tests were conducted with only a one-month interval to measure retention of the knowledge. This was because the students stayed in the training centers only for three months. This short span of time was not adequate to identify any changes between the two post-tests. Therefore, only the immediate impact of attending the reproductive health sessions could be measured.

\section{DESCRIPTION OF ACTIVITIES}

The project activities included modification of the curriculum, training of trainers, sensitization meetings with peer teachers, and implementing the reproductive health curriculum in the selected Youth Training Centers. These activities are described below.

\section{Adaptation of the reproductive health curriculum}

Before introducing the reproductive health curriculum developed under the Global Youth study in the vocational training courses, certain modifications were made. The curriculum of the Bangladesh Global Youth project was developed to address the reproductive health education needs of secondary school students whose age varied from 13 to 15 years, while the Department of Youth Development addresses older youth, ages 18-24. Therefore, the curriculum was modified to make it age appropriate. In addition, a session on family relationships, friendships, and values was added to strengthen young people's positive values and familial ties. Similarly, another session on advocacy for reproductive health education was added. This was mainly to encourage the trainees to advocate for reproductive health information per their needs.

The curriculum was also updated to incorporate new information including reproductive health life skills as described in "Skills for Health" (WHO 2003), and the recently developed and widely discussed "Condoms, Needles and Negotiation" skills approach for prevention of STIs and HIV. Two other curricula were also reviewed to update and modify the reproductive health 
curriculum, the "Know Yourself" facilitator workbook series developed by the Bangladesh Center for Communications Program (BCCP), and the "Personal Social Education” curriculum developed by UNFPA.

The original curriculum consisted of 17 sessions averaging 45 minutes each. In order to condense the curriculum into 10 sessions of 60 minutes each, general sessions on environment and safe water, food and nutrition, child health and immunization were excluded, while separate sessions on personal hygiene, marriage and rights, and population were merged with other sessions.

Conventional education aims to improve reproductive health knowledge and attitudes, while there is a growing understanding that it is necessary to improve life skills in order to change behavior and to assist young people in managing their reproductive health. Life skills enable young people to challenge harmful gender norms, resist peer pressure, and critically assess mass media stereotypes. In general, life skills can be grouped under communication and interpersonal skills, decisionmaking and critical thinking skills, and coping and self-management skills (WHO 2003). Depending on culture, different abilities can be emphasized.

The reproductive health curriculum used interactive and lively teaching methods such as stories, quizzes, riddles, debates, visuals, and discussions. Considering the age of the students, detailed information was provided regarding misconceptions about condoms, the proper use of condoms, and safe sex through the use of condoms. Life skill approaches were included to assist youth in averting risk behaviors. The substance abuse session offered youth negotiation and critical thinking skills to avert media as well as peer pressure. Similarly, the sexual relations session depicted the ways to negotiate in order to ensure either abstinence or safe sex, and also to avert sexual abuse. The gender session illustrated the differences between equity and equality and the effects of gender discrimination on the reproductive health of women. The safe motherhood session included discussion on the male's responsibility to ensure both the health of the mother and the child.

The curriculum also included session plans to assist the instructors in their lesson planning. The session plans included objectives of the session, information on why the topic is important, materials, methods, and the required time for the session. A colorful banner was developed for display in the classroom that depicted the 10 reproductive health topics, the goal of the course, and objectives (Photo and Figure 1). In the banner, the sessions were presented as the steps of a ladder, with the first session at the bottom and one session leading up to another. Before starting the session, the students could see from the banner what the class was about to discuss on a particular day, and where they were in terms of the learning objectives of the course.

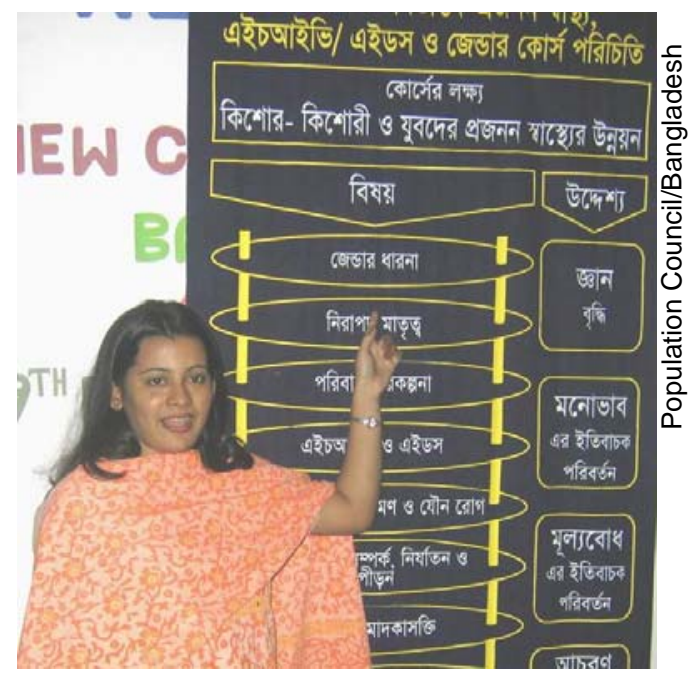

A trained teacher at the Brahmanbaria Youth Training Center explains the lesson plan in the class. 
Figure 1. Banner depicting the reproductive health course goal, topics, and objectives

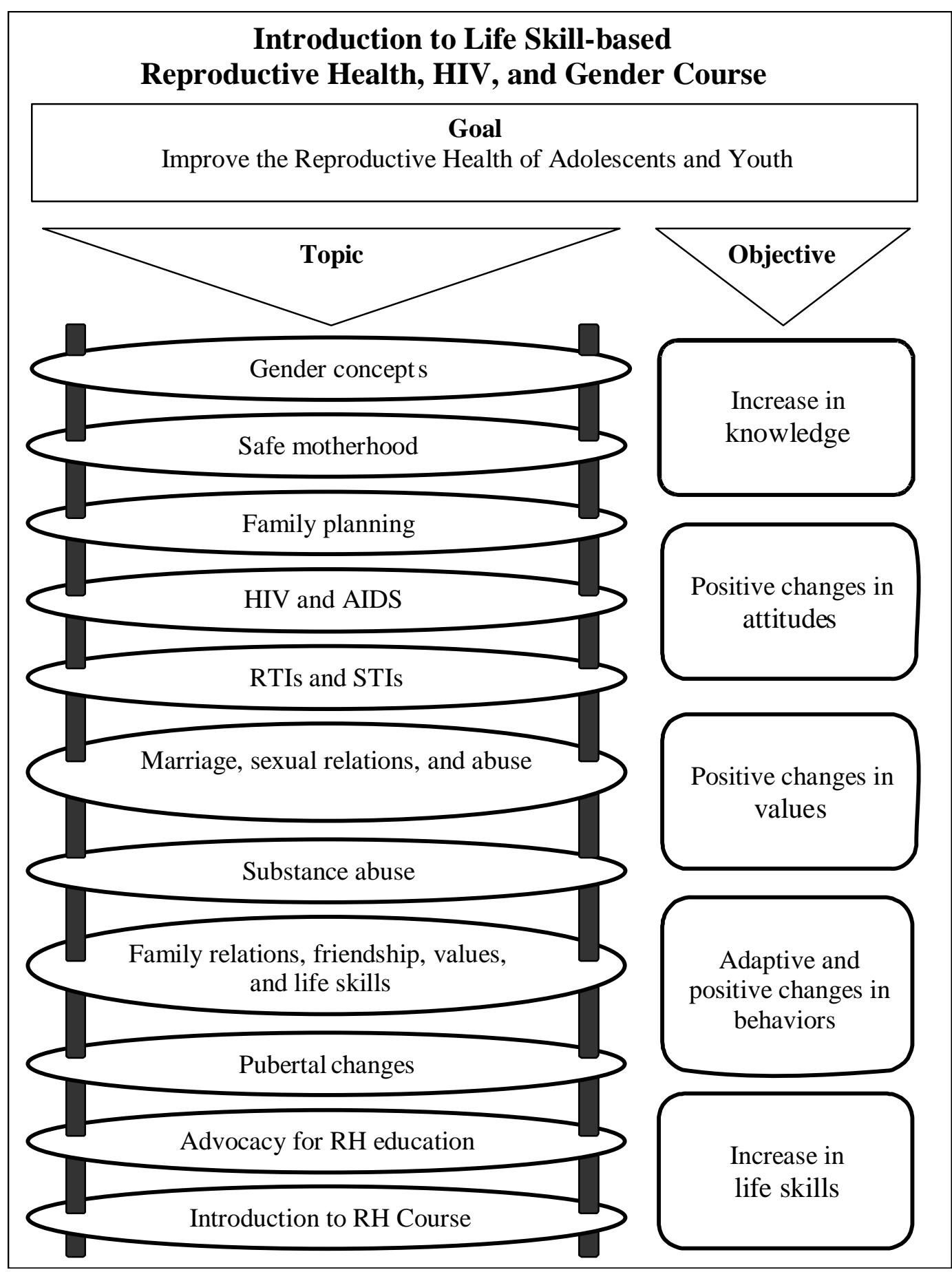




\section{Training of trainers}

The Department of Youth Development selected two participants from each of the five Youth Training Centers to implement the curriculum and attend the training of trainers (TOT). The selected participants included four Deputy Coordinators, four Community Development Officers, one Senior Instructor, and one Instructor. Four of five planned participants were females, as one YTC did not have any female instructors. The reproductive health curriculum was introduced in the Youth Training Centers as a part of the department's regular course entitled "Youth Development." Therefore, the Community Development Officers who are responsible to impart this course were selected as trainers. Deputy Coordinators who are primarily responsible for managing the Youth Training Centers were also selected because as managers, they were in a better position to introduce reproductive health education in the training institutions.

In September 2004, a five-day TOT was conducted in Dhaka. Population Services and Training Center (PSTC), one of the partners of the USAID-funded NGO Service Delivery Program (NSDP), conducted the training. The PSTC has many years of experience in providing

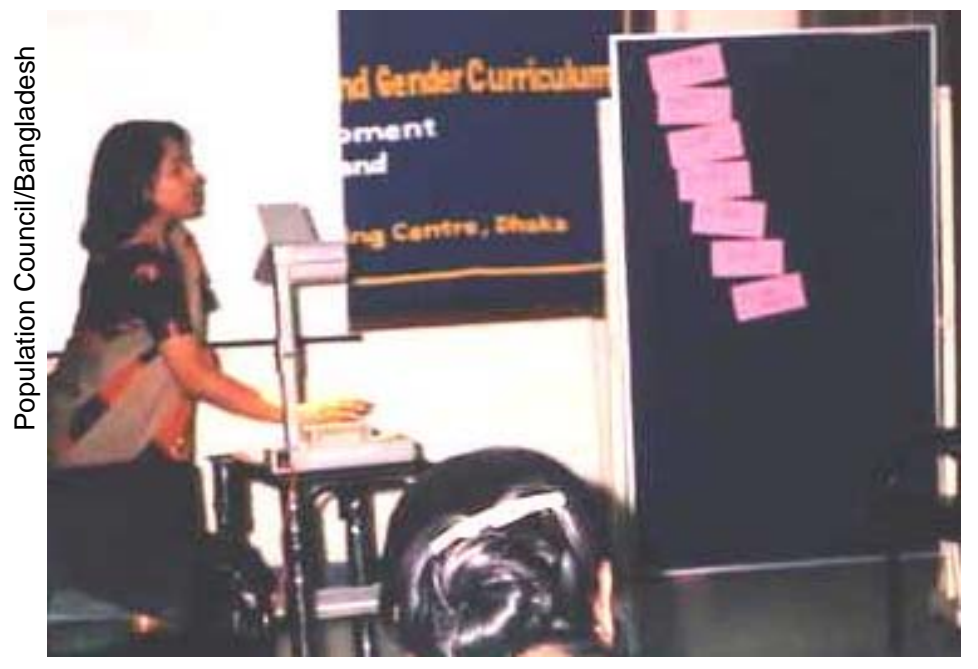

A trainer conducting a facilitation skill session in the TOT. reproductive health training and also conducted the training of the community facilitators and teachers for the earlier Global Youth project. In addition to PSTC trainers, two project directors of the Department of Youth Development, who had previously received training on reproductive health issues sponsored by UNFPA and the Population Council, conducted sessions on gender and changes during adolescence, while the Director of Implementation and a former family planning official jointly facilitated the session on family planning. The PSTC and the resource persons received session plans and transparencies well in advance so that they could prepare for the training.

The Deputy Director of Training of the Department of Youth Development and Population Council staff jointly coordinated and monitored the training of trainers (TOT). The Deputy Director coordinated with the department and the five district offices so that the selected Youth Training Center officials could participate in the training. He also ensured the participation of different levels of Department of Youth Development resource persons and officials for effective collaboration. The Director General of the Department of Youth Development inaugurated the TOT, and all Directors attended the closing ceremony to encourage the trainees to introduce the reproductive health education in their respective training centers. Population Council staff were responsible for overall coordination among the three participating organizations, as well as training materials, facilitators, and resource persons. 
In order to ensure the effectiveness of the training and to build the capacity of the trainees, the training was rigorously monitored and evaluated. Due to the continual presence of the Deputy Director, the trainees were keen to demonstrate their best performance. Population Council staff assisted the resource persons to maintain the quality of the training, especially in delivering information and in the use of materials and methods. In the process of monitoring, key information gaps were addressed in the daily review and feedback sessions. For example, one of the resource persons did not discuss gender roles and could not appropriately use the overhead projector, issues which were addressed in the review session.

There were three distinct steps in the training of trainers (the lesson plan is depicted in Annex B). The first two days were devoted to teaching the topics of the 10 reproductive health sessions. Key materials used included transparencies with text and visuals, flip charts, and markers. Different combinations of participatory and interactive techniques were employed such as debates, story telling, quizzes, riddles, group discussions, case studies, and lectures. However, a single session did not use all the techniques. For instance, debate was used in the advocacy for reproductive health education session, riddles in the RTI/STI session, story telling and quizzes in HIV and AIDS session, while group discussions and brief lectures were

\section{Box 1. Facilitation criteria}

- Facilitation skill

- Knowledge and understanding of topic

- Friendliness and non-judgmental attitude

- Incorporating participants in discussion

- Use of training materials

- Selection and use of training methods

- Use of proper language

- Eye-contact and body language (change of position, use of hands)

- Time management common in all the sessions. In addition to the reproductive health sessions, one session on facilitation techniques was conducted and the facilitation observation checklist was introduced (Box 1 and Annex C).

The second step was to hold practice sessions for two days where each participant conducted a forty-five minute session using the same materials and methods as they would at their training institutions. On the second day of the training, the 10 sessions were distributed at random among the trainees so that they could prepare for their respective sessions on days three and four. The facilitators also kept themselves available in the late afternoon and early in the morning so that the participants could receive further assistance, clarification, and guidance. At the end of each of the practice sessions, all participants including the facilitators and monitors evaluated the session and discussed the strengths and weaknesses of the participant using the facilitation observation checklist. The participants received detailed feedback on knowledge gaps, facilitation techniques, body language, handling of material, use of language, and time management. As a result, all participants became more confident in implementing the curriculum.

During the training of trainers, a few problems with language and information were identified and were subsequently modified in the final version of the curriculum. For example, the age limit of youth of " 15 to 30 years" was changed to " 18 to 35 years" following the revised definition of the Ministry of Youth and Sports. An unclear visual of the five danger signs relating to pregnancy was replaced with five distinct and clear visuals. The sequence of two of the sessions 
was also changed, because it seemed more appropriate to conduct the gender session at the end to better understand the effects of gender imbalance on the reproductive health of women. The training of trainers thus provided an opportunity for further refinement of the curriculum before it was introduced in the youth training institutions.

As the third and final step, in consultation with the Deputy Director of Training, the participants developed implementation plans to conduct sessions at the Youth Training Centers. These plans included pre- and post-test dates as well as two review sessions for discussion of key lessons learned from the course. The Director General approved the plans for implementing the reproductive health curriculum in the Department of Youth Development training institutions. In order to measure the changes among the instructors attending the TOT, pre- and post-tests were conducted before and after the training, and the successful participants were awarded with certificates.

\section{Conducting sensitization meetings with peer teachers}

To motivate the other faculty and staff of the five selected training institutions, the Department of Youth Development and Population Council staff organized sensitization meetings prior to holding the pre-test and introducing reproductive health education with the students. About 12 participants per institution, including four peer teachers, were present in the 45-minute long meetings. The peer teachers were informed about the reproductive health needs of young people, the program of curriculum implementation, and the process of evaluation. The participants were also encouraged to ask questions and express doubts, if any, about the program. One peer teacher in Naogaon expressed concerns about the repercussions of introducing such sensitive issues. Through discussion, it was apparent that introduction of the course after rapport building with the students would reduce the possibilities of unanticipated consequences. In response to another teacher's request for clarification on his involvement in the program, peer teachers were requested to cooperate with the trained teachers in imparting the reproductive health education. By providing a clear idea about the program and responding to queries, the sensitization meetings ensured cooperation and support from peer teachers and other staff of the institutions. As such, they enthusiastically attended the pre- and post-test surveys and helped the designated reproductive health teachers in conducting sessions with flexible and extended hours. One peer teacher became very interested in the curriculum, and in the absence of a trained teacher due to an emergency, conducted two sessions.

\section{Implementation of the reproductive health curriculum}

After administering the pre-test survey among the students, the trained teachers of the Department of Youth Development began implementing the reproductive health curriculum among the students enrolled in the Youth Training Centers for the October-December 2004 session. This reproductive health curriculum was made a part of the regular subject of the "Youth Development” course, and 10 sessions were conducted during October and November 2004. 
Two trained teachers from each of the Youth Training Centers conducted five sessions each, depending on their individual level of comfort and skill. For example, the teachers in three centers with science background conducted sessions on changes during adolescence, RTI/STIs, HIV and AIDS, and family planning, while the other teachers taught sessions on family relations, friendship, values, life skills, and gender. Academic background was not found to be an imperative criterion to teach the subjects. Two sincere and enthusiastic trainers easily conducted the same sessions by actively participating in the training and using the curriculum as well as supplementary materials. Moreover, the teachers could manage any of the above sessions by adopting deferring and referring techniques in responding to a difficult question, if asked. Marital status was found to be an added advantage but not necessary in imparting reproductive health education to young people. For instance, in two centers, unmarried female and male teachers felt discomfort in discussing condoms; hence the married male and female teachers assisted the unmarried teachers in conducting the session. However, in one center, a friendly, young, unmarried female facilitator comfortably conducted the same session. Thus, teachers who are sincere, enthusiastic, friendly, and non-judgmental are

Box 2. Reproductive health session training materials

- Teacher curriculum

- Student reading materials

- Overhead projector

- Transparencies

- Story leafs

- White board and marker

- Banner and post box

- Microphone

- Compact discs (CDs) suitable to conduct reproductive health education sessions as these qualities encourage youth to actively participate in reproductive health sessions. Marital status and science background were found to be useful but not decisive factors in teacher performance.

In general, when one trained teacher conducted a session, the other teacher co-facilitated. Sometimes peer teachers were also present to observe the session and to assist in managing the class if needed. The two teachers in the Savar center, which had twice the number of students as the other centers, conducted sessions in two sections, while the pairs of teachers in other centers only had one section.

In conducting the sessions, the teachers employed a number of participatory and lively methods. The focus group discussions revealed that students enjoyed the open discussion that took place in every session followed by a brief lecture and story telling. A list of the training materials is shown in Box 2. The teaching aides such as the curriculum, transparencies, and story leafs were provided during the training of trainers. Story leafs contained stories in friendly and larger font with visuals that made it easier for students to read aloud in the class. Students were also given reading materials, that is, one book for a team of five students who stayed in the same room. This allowed the students to read the book in a study group for better understanding and internalization. In addition, a set of four compact discs (CDs), "Know Yourself” developed by the Adolescent Reproductive Health Working Group, was also provided to each of the trainers. Due to problem with the computers, only one of the centers (Brahmanbaria) was able to use the CDs. 
A question box placed in a suitable location allowed students to raise questions anonymously. Questions that could not be asked in the session due to time constraints were also dropped in the box. In the focus group discussions, students identified transparencies, the question box, and reading material as the most useful materials. However, they suggested developing colorful transparencies for enhancing the visualization, and requested that each student receive a personal copy of the book. In informal discussions, the

\section{Box 3. Reading materials}

"An individual copy of the reading materials is crucial because if we have it, then we can motivate others that we are telling the truth. And, how can we remember everything for long if we do not have anything with us?"

Student participating in the reproductive health course at one of the five YTCS teachers relayed that the curriculum, transparencies, and the question box were the most useful training materials for them. The lesson plan banner was posted on the wall in each of the classrooms to show students the objectives and contents of a session and the topics. With the banner, the teachers could refer to the previous session and initiate discussion about the current session. At the end of each session, the teachers encouraged the students to ask questions.

Teachers also asked questions in order to understand if the objectives of increased knowledge, changed attitudes, and increased life skills were being achieved. For example, correct mention of the five danger signs of pregnancy indicated an increased level of knowledge; statements made in favor of drying menstrual cloths in direct sunlight meant positive change in attitude, and decisions made to give up smoking indicated increased life skills (see Box 4).

Focus group discussions and in-depth interviews revealed that the question box was useful for both students and teachers. The questions helped teachers in understanding the knowledge gap on a particular topic; simultaneously it allowed students to reflect their opinions and ask questions without feeling any discomfort. A total of 380 note slips were dropped in the question boxes of the five Youth Training Centers. Most of the questions were related to reproductive and sexual organs followed by sexual relations, family planning, condoms, HIV and AIDS, and wet dreams (Table 2).

The wide variety of questions revealed the concerns and the dilemmas faced by the young people. For example, a 21-year old young man, who could not

\section{Box 4. Decision to quit smoking}

"From today I'm going to give up smoking. l'll also pursue my friends not to smoke."

A 19-year old unmarried male youth in Savar avowed at the end of the session on substance abuse afford to get married within the next seven to eight years, sought advice to give up masturbation because he believed that it was an unhealthy practice. Questions on HIV-including if the virus can be transmitted through wet dreams, masturbation, or by being attracted to a girl—indicated that there were misconceptions on HIV and AIDS. Many questions were asked about condoms, family planning, and sexual relations, which enabled teachers to address these sensitive issues. The teachers answered most of the questions in the classroom. For questions related to diseases, students were advised to visit qualified doctors, government hospitals, or NGO clinics. Students in one section of Savar complained that they could not freely drop questions because the box was placed in an inconvenient location. 
Table 2. Distribution of questions deposited in question boxes of the five Youth Training Centers

\begin{tabular}{|c|c|}
\hline Topic & $\begin{array}{l}\text { Number of } \\
\text { questions* }\end{array}$ \\
\hline Reproductive and sexual organs & 105 \\
\hline Penis/testes/scrotum & 55 \\
\hline Premature ejaculation & 13 \\
\hline Seminal fluid/ejaculation/sperm & 9 \\
\hline Breasts/uterus/vagina & 9 \\
\hline Sexual ability/sexual urge & 16 \\
\hline Other body parts (groin, hand, mouth, tongue)/treatment & 3 \\
\hline Menstruation & 11 \\
\hline Wet dreams & 33 \\
\hline Masturbation & 22 \\
\hline Sexual relations & 68 \\
\hline Attraction & 14 \\
\hline Marriage/divorce & 15 \\
\hline Intercourse/sexual pleasure & 36 \\
\hline Extra-marital relations/homosexuality & 3 \\
\hline Sexual abuse and harassment (rape, dowry, child marriage) & 14 \\
\hline RTI/STIs (symptoms, transmission, treatment, and others) & 26 \\
\hline HIV and AIDS (transmission, symptoms, and others) & 34 \\
\hline Family Planning & 35 \\
\hline Injection/implants/IUD/pill/ECP/tubectomy/vasectomy & 13 \\
\hline Natural methods/infertility/timing/others & 22 \\
\hline Condoms & 29 \\
\hline Childbirth (prolonged labor, sex preference, test-tube baby, others) & 13 \\
\hline Substance abuse (smoking and advocacy) & 8 \\
\hline Teachers and/or reproductive health education program & 16 \\
\hline Others (general diseases/conditions, gender, body, health facility and others) & 30 \\
\hline Total & 444 \\
\hline
\end{tabular}

*45 out of 380 note slips contained multiple topic questions.

As per the class routine of the Youth Training Centers, four hours of conceptual classes usually take place before the lunch break while practical sessions are held in the afternoon. The allocated time for the youth development subject was three hours per week in the morning. As a part of this subject, a total of 10 hours were allotted for the 10 reproductive health sessions in addition to a session on introduction to the course. The introductory session was designed to elicit information about the students' expectations and concerns about the course, and to set the ground 
rules of participation. Another five hours was included for two review sessions and three surveys. Thus, a total of 15 hours was allotted for the reproductive health course and evaluation activities, whereas the Department of Youth Development usually allocates 10 hours for discussion of reproductive health-related issues. The extra five hours and extended classes put pressure on the overall schedule of the youth development course.

To ensure a one-month gap between the immediate and final post-tests, the sessions were conducted more frequently as needed, instead of three sessions a week. In a few cases, sessions were conducted for a longer period or in the afternoon, with permission from the peer teachers, to allow for elaborated discussions on difficult and time consuming topics such as HIV and AIDS, marriage, sexual relations, violence and abuse, and gender. These sessions required more time, about one and a half hours to two hours. The session duration varied with the class size, as larger classes required longer hours to respond to the greater number of questions. Thus, instead of 10 hours, the 10 reproductive health sessions required 12 to 15 hours. Twelve hours was found to be suitable for a class size of 40 and fifteen hours for a group of more than 40 students.

Per the objectives of the Department of Youth Development, the five Youth Training Centers were supposed to reach 600 students, with 100 students per batch (70 males and 30 females). However, the total number of enrolled students was 541, which was further reduced to 496 due to dropouts, of which nine percent were females (Table A.1). The number of students was the highest in Savar and the lowest in Hobiganj. According to a Department of Youth Development official, the youth in this particular district are less interested in attending the certificate course on livestock, poultry, fisheries, and agriculture. According to the rules of the Department of Youth Development, students are allowed a maximum of five days leave within the three-month training period. Leaving the campus beyond this time is restricted and students face a penalty, a proportionate loss in their security deposit for any unauthorized leave. Not all enrolled students attended the pre-test due to leave and absence on the day of the survey. Similarly, not all students who were present at the pre-test attended all reproductive health sessions, and five students did not attend any of the sessions.

\section{Box 5. Interest in attending reproductive health sessions}

"Students were eager to attend the reproductive health sessions. I could give extra sessions in the afternoon just because of their keen interest. They even come to my room asking a lot of questions."

The female teacher in Kishoreganj

The attendance records of the 450 students who gave consent to attend the pre-test and to participate in the reproductive health sessions revealed that two-fifths of students attended all sessions and 92 percent of the students who participated in the pre-test attended more than five sessions. The number of students who attended a maximum of five sessions was the highest in Hobiganj (Tables 3 and A.2). 
Table 3. Distribution of students who attended reproductive health sessions by training centers

\begin{tabular}{|c|c|c|c|c|c|c|c|c|c|c|c|c|}
\hline \multirow{2}{*}{$\begin{array}{l}\text { Youth } \\
\text { Training } \\
\text { Centers }\end{array}$} & \multicolumn{11}{|c|}{ Number of sessions } & \multirow{2}{*}{ Tota } \\
\hline & 0 & 1 & 2 & 3 & 4 & 5 & 6 & 7 & 8 & 9 & 10 & \\
\hline Brahmanbaria & 3 & 1 & 1 & 0 & 1 & 0 & 1 & 1 & 20 & 6 & 41 & 75 \\
\hline Hobiganj & 2 & 4 & 1 & 0 & 1 & 5 & 3 & 2 & 10 & 6 & 8 & 42 \\
\hline Kishoreganj & 0 & 0 & 0 & 3 & 1 & 1 & 5 & 6 & 15 & 25 & 25 & 81 \\
\hline Naogaon & 0 & 1 & 2 & 1 & 3 & 1 & 6 & 8 & 11 & 22 & 35 & 90 \\
\hline Savar & 0 & 1 & 2 & 0 & 0 & 3 & 6 & 13 & 24 & 35 & 78 & 162 \\
\hline Total & 5 & 7 & 6 & 4 & 6 & 10 & 21 & 30 & 80 & 94 & 187 & 450 \\
\hline
\end{tabular}

The attendance rate was the lowest in Hobiganj and the highest in Savar (Table 4). The overall reproductive health class attendance in five centers was 84 percent. Thus, the average class size was 63 considering Savar had two sections. The low rate of attendance in Hobiganj was due to the higher leave-taking propensity of students as compared to other centers.

Table 4. Average attendance rates at reproductive health sessions by sex and training centers

\begin{tabular}{lrcrr}
\hline YTC & Female & Male & Total & Number \\
\hline Brahmanbaria & 91.0 & 85.1 & 85.9 & 75 \\
Hobiganj & 86.3 & 62.4 & 66.9 & 42 \\
Kishoreganj & 92.2 & 83.6 & 84.6 & 81 \\
Naogaon & 90.0 & 83.3 & 83.7 & 90 \\
Savar & 96.3 & 88.1 & 88.5 & 162 \\
Total & 91.3 & 83.7 & 84.4 & \\
$\mathbf{N}$ & $\mathbf{4 0 *}$ & $\mathbf{4 1 0 ^ { * }}$ & $\mathbf{4 5 0 *}$ & $\mathbf{4 5 0 ^ { * }}$ \\
\hline
\end{tabular}

*Note: Includes the students who gave consent to participate in the self-administered surveys and attend the $\mathrm{RH}$ course.

Focus group discussions and interviews with students and teachers confirmed that students who were present on campus were most likely to attend the reproductive health course. The attendance rates of other subjects were not available, but both students and teachers reported that the students were more interested in attending the reproductive health sessions due to the content, materials, and teaching methods. Attendance rates were higher among the females as compared to their male counterparts. Participation also varied from session to session. The 10 reproductive health sessions were attended by over 80 percent of the students, with the exception of the safe motherhood session. The highest attendance rate (94\%) was in the session on family relations, friendship, values, and life skills (Figure 2). The safe motherhood session marked the 
lowest rate of attendance because it was scheduled around the Islamic holiday of Eid when students took extra days off to celebrate with their family and friends at home.

Figure 2. Percent distribution of students who attended specific reproductive health sessions

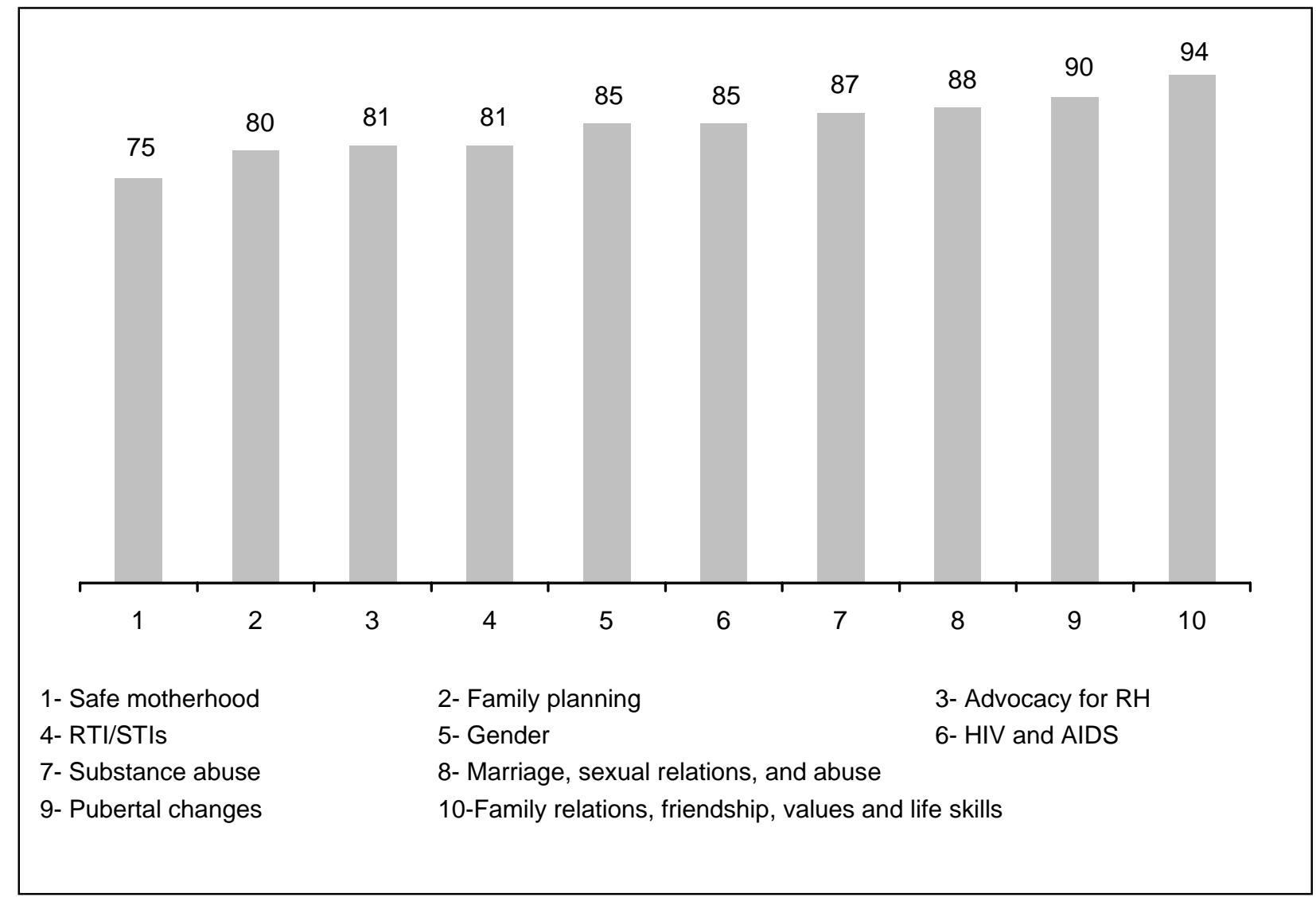

\section{FINDINGS}

Findings on the background characteristics of students as well as their knowledge, attitudes, skills, and opinions on reproductive health education are presented in this section. The age group for enrolment in the youth training centers is 18 to 35 years. However, a few students below and above the required age limit were found in the survey. In this report, only students up to 35 years have been incorporated for analysis. For lack of variation between immediate and final posttests, only comparisons between the pre- and final post-tests have been carried out to measure the changes due to the reproductive health education. 


\section{Socio-demographic characteristics of students}

Most of the students who attended the reproductive health sessions were between 16 and 24 years of age. The average age of the students was 23, and about 10 percent were female. About two-thirds of the students had a secondary education (8-10 years of schooling) (Table 5). Around one-third of the students were also currently enrolled in other educational institutions (not shown).

Less than one-fifth of the students were currently married (Table 5). The average age at marriage was 19.5 years for girls and 24.5 years for boys. One-fifth of married girls and one-tenth of married boys reported getting married before the legal age of marriage, 18 and 21, respectively (not shown).

In congruence with the national statistics, students were predominantly Muslim, and about threefourths of them resided in rural areas (Table 5). About two-thirds of the students had ever worked for pay, while only one-fourth of them were currently working. As expected, the number of respondents with working experience was higher among the older age group (not shown).

Table 5. Background characteristics of students

\begin{tabular}{ll|ll}
\hline Characteristics & Percent & Characteristics & Percent \\
\hline Age & & Marital status & \\
Less than 20 & 25.1 & Single & 81.8 \\
$20-24$ & 44.6 & Married & 17.5 \\
$25-29$ & 18.9 & Separated & 0.7 \\
30 and above & 11.4 & $\mathrm{~N}$ & 439 \\
Mean & 23.0 & Religion & \\
N & 439 & Islam & 93.6 \\
& & Others & 6.4 \\
Sex & & N & 439 \\
Female & & Place of residence & \\
Male & 9.1 & Rural & 72.1 \\
N & 90.9 & N & 438 \\
Education & 439 & Working status & \\
8-10 years schooling & & Ever worked for pay & 64.4 \\
More than 10 years schooling & 36.6 & $\mathrm{~N}$ & 438 \\
$\mathrm{~N}$ & 437 & Currently working for pay & 27.2 \\
\hline
\end{tabular}

*All background information was collected during the pre-test survey.

Not all students who took the pre-test took the post-test. Statistical tests were carried out to identify differences between the two groups of the students (Table 6). There were no differences between the groups except a significantly higher number of males $(\mathrm{p}<0.01)$ and students who were currently working $(p<0.10)$ were absent for the post-test. 
Table 6. Background characteristics of students who attended the final post-test survey and those who did not

\begin{tabular}{|c|c|c|}
\hline Characteristics & $\begin{array}{l}\text { Percent who attended } \\
\text { both pre- and final post- } \\
\text { tests }\end{array}$ & $\begin{array}{l}\text { Percent who } \\
\text { did not attend } \\
\text { final post-test }\end{array}$ \\
\hline \multicolumn{3}{|l|}{ Age } \\
\hline Less than 20 & 25.6 & 21.7 \\
\hline $20-24$ & 43.8 & 50.0 \\
\hline $25-29$ & 19.3 & 16.7 \\
\hline 30 and above & 11.3 & 11.7 \\
\hline Mean & 23.0 & 22.8 \\
\hline $\mathrm{N}$ & 379 & 60 \\
\hline \multicolumn{3}{|l|}{ Sex } \\
\hline Female & 10.3 & $2.0^{* \star}$ \\
\hline Male & 89.7 & $98.0^{* \star \star}$ \\
\hline $\mathrm{N}$ & 379 & 60 \\
\hline \multicolumn{3}{|l|}{ Education } \\
\hline 8-10 years schooling & 63.0 & 66.1 \\
\hline More than 10 years schooling & 37.0 & 33.9 \\
\hline $\mathrm{N}$ & 378 & 59 \\
\hline \multicolumn{3}{|l|}{ Marital status } \\
\hline Single & 81.5 & 83.3 \\
\hline Married & 17.7 & 16.7 \\
\hline Separated & 0.8 & - \\
\hline $\mathrm{N}$ & 379 & 60 \\
\hline \multicolumn{3}{|l|}{ Religion } \\
\hline Islam & 93.7 & 93.3 \\
\hline Others & 6.3 & 6.7 \\
\hline $\mathrm{N}$ & 379 & 60 \\
\hline \multicolumn{3}{|l|}{ Place of residence } \\
\hline Rural & 73.0 & 66.7 \\
\hline Urban & 27.0 & 33.3 \\
\hline $\mathrm{N}$ & 378 & 60 \\
\hline \multicolumn{3}{|l|}{ Working status } \\
\hline Ever worked for pay & 63.5 & 70 \\
\hline $\mathrm{N}$ & 378 & 60 \\
\hline Currently working for pay & 25.7 & $36.7^{*}$ \\
\hline $\mathrm{N}$ & 378 & 60 \\
\hline
\end{tabular}

*Significant at $p<0.10 ;{ }^{\star \star} p<0.05 ;{ }^{* \star} p<0.01$. 


\section{Knowledge of reproductive health issues}

\section{Knowledge of physical changes in girls and boys during adolescence}

Knowledge about changes in the opposite sex was emphasized in the course for increasing shared responsibilities, understanding and caring. Pre- and post-test results show significant improvement in knowledge about physical changes among the opposite sex during adolescence, particularly among the younger age groups (Table A.3). Despite the fact that menarche was identified by the majority of the girls (93\%) as one of the natural changes associated with puberty, misconceptions regarding menstruation still exist.

\section{Knowledge of contraceptive methods}

Information about contraceptive methods is important for enhancing options for young people in avoiding unintended pregnancy. A comparison between pre- and post-tests showed a significant increase in knowledge among students regarding the fertile period, the dual role of condoms, the intrauterine device (IUD), implants, and emergency contraception (Table A.4).

Knowledge about the fertile period, the time of the month a woman is most likely to get pregnant if she has sexual relations, increased significantly, almost doubling after the intervention. The increase was significantly higher among those less than 25 years old. Knowledge about the pill and injectable was already high, as over four-fifths of the students reported having heard about these methods. Knowledge about the IUD and implants was the lowest at the pre-test but increased significantly in the post-test (from 30 to 95\%) (Table A.4).

Raising awareness about condoms is crucial for reducing gender imbalance in the use of contraceptive methods and more importantly to prevent STIs and HIV. Almost all respondents (97\%) had heard about condoms; however, less than two-thirds of students were aware of the dual protection condoms offer. This knowledge increased significantly to 89 percent in the posttest, and the increase was greater among females.

The knowledge about emergency contraceptive pills (ECP) is also important for avoiding unintended pregnancy and care of rape survivors. In the pre-test, about two-fifths of the students had heard about ECP while less than one-fifth knew that ECP is used for avoiding unintended pregnancy. After the reproductive health course, the proportion of students who had heard about ECP increased from 42 percent at the pre-test to 93 percent at the post-test, and two-thirds of them could mention the reasons for use of ECP (Table A.4). The change was more significant among females.

\section{Knowledge of sex determinants of a child and five danger signs during pregnancy}

Being a patriarchal society with a high level of gender imbalance, son preference is common and women are usually held responsible if a son is not born. Therefore, the reproductive health sessions included information about both sex determination of a child and gender discrimination that prevails in the society. Because knowledge about the life-threatening conditions related to pregnancy is a pre-requisite for reductions in maternal mortality and morbidity, the five danger signs related to pregnancy (i.e., prolonged labor for more than 12 hours, high fever and 
headache, severe headache and blurry vision, excessive bleeding, and convulsion) were also discussed.

Findings presented in Table 7 show that the knowledge levels of the students regarding sex determination of a child - only the father, or the chromosome of the father, determines the sex of a child - increased significantly after attending the reproductive health sessions (from $26 \%$ to $76 \%$ ). The change was significant across all age groups and greater among male respondents. Knowledge about danger signs of pregnancy also increased significantly for both sexes, especially among the younger respondents. Over 90 percent of the respondents in the post-test reported knowing all five danger signs of pregnancy (Tables 7 and A.5).

Table 7. Percent distribution of students' correct knowledge about sex determination of a child and pregnancy-related danger signs by sex and time of survey

\begin{tabular}{|c|c|c|c|c|c|c|}
\hline \multirow[t]{2}{*}{ Topics } & \multicolumn{2}{|l|}{ Female } & \multicolumn{2}{|l|}{ Male } & \multicolumn{2}{|l|}{ Total } \\
\hline & Pre-test & $\begin{array}{l}\text { Post- } \\
\text { test }\end{array}$ & Pre-test & Post-test & Pre-test & Post-test \\
\hline $\begin{array}{l}\text { Who determines } \\
\text { sex of a child }\end{array}$ & 35.9 & $71.8^{\star \star}$ & 25.2 & $76.5^{\star \star}$ & 26.1 & $76.0^{\star \star}$ \\
\hline $\mathrm{N}$ & 39 & 39 & 397 & 340 & 436 & 379 \\
\hline \multicolumn{7}{|c|}{ Danger signs of pregnancy } \\
\hline $\begin{array}{l}\text { Prolonged } \\
\text { labor }\end{array}$ & 65.0 & $94.9^{* *}$ & 76.1 & 95.9 ** & 75.1 & $95.8^{\star \star}$ \\
\hline $\mathrm{N}$ & 40 & 39 & 397 & 339 & 437 & 378 \\
\hline $\begin{array}{l}\text { High fever and } \\
\text { headache }\end{array}$ & 55.6 & $92.3^{\star \star}$ & 64.4 & $96.7^{\star \star}$ & 63.6 & $96.3^{\star \star}$ \\
\hline $\mathrm{N}$ & 36 & 39 & 376 & 338 & 412 & 377 \\
\hline $\begin{array}{l}\text { Severe } \\
\text { headache and } \\
\text { blurry vision }\end{array}$ & 61.1 & $97.4^{\star \star}$ & 68.8 & $95.0^{* *}$ & 68.2 & $95.2^{* *}$ \\
\hline $\mathrm{N}$ & 36 & 39 & 385 & 338 & 421 & 377 \\
\hline $\begin{array}{l}\text { Excessive } \\
\text { bleeding }\end{array}$ & 63.9 & $87.2^{\star *}$ & 64.3 & $90.2^{\star \star}$ & 64.3 & $89.9^{* *}$ \\
\hline $\mathrm{N}$ & 36 & 39 & 378 & 338 & 414 & 377 \\
\hline Convulsion & 68.6 & $97.4^{\star *}$ & 63.5 & $94.1^{*}$ & 63.9 & $94.4^{\star *}$ \\
\hline $\mathrm{N}$ & 35 & 39 & 378 & 338 & 413 & 377 \\
\hline
\end{tabular}

*Significant at $p<0.05 ; * \star p<0.01$.

\section{Knowledge of STIs, HIV and AIDS}

Building the correct knowledge base on STIs, HIV and AIDS is a high priority for reproductive health education. A comparison between pre- and post-test surveys showed a significant increase in knowledge about the routes of transmission of STIs, including sex without condoms (81 to 
$96 \%, \mathrm{p}<0.01$ ), unsterilized blood transfusion (76 to 93\%, $\mathrm{p}<0.01$ ), sharing needles (80 to $88 \%$, $\mathrm{p}<0.01$ ) and mother to child transmission (62 to $82 \%, \mathrm{p}<0.01$ ). The increase in knowledge was markedly higher among males and respondents less than 20 years old (Table A.6).

Misconceptions about routes of transmission of STIs were high (Table A.6). Due to the comparatively low level of knowledge before attending the sessions, the rate of increase in knowledge about how STIs are not transmitted (e.g., using soap or toilet, clothes, sweating, and saliva) was greater compared to that of transmission of STIs. Increased knowledge was significant and higher among the males and those less than 20 years old. Students' correct knowledge about what to do in order to treat STIs significantly increased to over 97 percent (Table A.7). The knowledge that medicines should not be stopped even when the symptoms disappear increased by 42 percentage points. The comparatively lower STI-related knowledge among females underscores the need for the female students to receive more attention in discussing STIs. This performance could be due to either non-attendance at the particular session or social discomfort.

The findings indicate that reproductive health education has also had a significant impact on the knowledge about measures to prevent HIV. The increases were the highest for limiting sexual contact and negotiation for safe sex with partner (Tables 8 and A.8). Negotiation for safe sex was included as an important preventive measure because even after knowing about the routes of transmission of STIs and HIV, youth may not be able to avoid risk behaviors due to lack of negotiation skills. The pre-test survey indicated that knowledge was relatively high about the use of condoms, use of sterilized syringes, and safe blood transfusion. It is notable that only twothirds of the respondents knew about abstinence in the post-test.

Table 8. Percent distribution of students' correct knowledge about prevention of HIV by age, sex and time of survey

\begin{tabular}{|c|c|c|c|c|c|c|}
\hline \multirow[t]{2}{*}{ Topics } & \multicolumn{2}{|l|}{ Female } & \multicolumn{2}{|l|}{ Male } & \multicolumn{2}{|l|}{ Total } \\
\hline & Pre-test & Post-test & Pre-test & Post-test & Pre-test & Post-test \\
\hline Abstinence & 32.5 & $59.0^{\star \star}$ & 52.3 & $67.1^{\star \star}$ & 50.5 & $66.2^{\star \star}$ \\
\hline $\mathrm{N}$ & 40 & 39 & 388 & 340 & 428 & 379 \\
\hline $\begin{array}{l}\text { Limit sexual contact } \\
\text { with only one } \\
\text { uninfected partner }\end{array}$ & 35.0 & 76.9 ** & 60.2 & $86.2^{\star \star}$ & 57.8 & $85.2^{\star *}$ \\
\hline $\mathrm{N}$ & 40 & 39 & 389 & 340 & 429 & 379 \\
\hline Use of condoms & 60.0 & $89.7^{\star \star}$ & 83.8 & $96.5^{\star \star}$ & 81.6 & $95.8^{\star \star}$ \\
\hline $\mathrm{N}$ & 40 & 39 & 390 & 340 & 430 & 379 \\
\hline Safe blood transfusion & 53.8 & $97.4^{\star *}$ & 75.7 & $93.5^{\star \star}$ & 73.7 & $93.9^{\star \star}$ \\
\hline $\mathrm{N}$ & 39 & 39 & 383 & 340 & 422 & 379 \\
\hline $\begin{array}{l}\text { Use of sterilized } \\
\text { syringe }\end{array}$ & 59.0 & $82.1^{*}$ & 74.7 & $89.7^{\star \star}$ & 73.3 & $88.9^{\star \star}$ \\
\hline $\mathrm{N}$ & 39 & 39 & 384 & 340 & 423 & 379 \\
\hline $\begin{array}{l}\text { Negotiate safe sex } \\
\text { with partner }\end{array}$ & 33.3 & $79.5^{\star \star}$ & 54.8 & $82.9^{\star \star}$ & 52.8 & $82.6^{\star \star}$ \\
\hline
\end{tabular}


*Significant at $p<0.05 ; * \star p<0.01$.

Reducing stigma is yet another challenge in the fight against HIV and AIDS. About half of the respondents already knew that you could not identify a person infected with HIV by his or her outward appearance. This increased significantly to over 80 percent in the post-test (Figure 3).

Figure 3. Percent distribution of students who knew that HIV cannot be detected by a person's appearance by sex and time of surveys

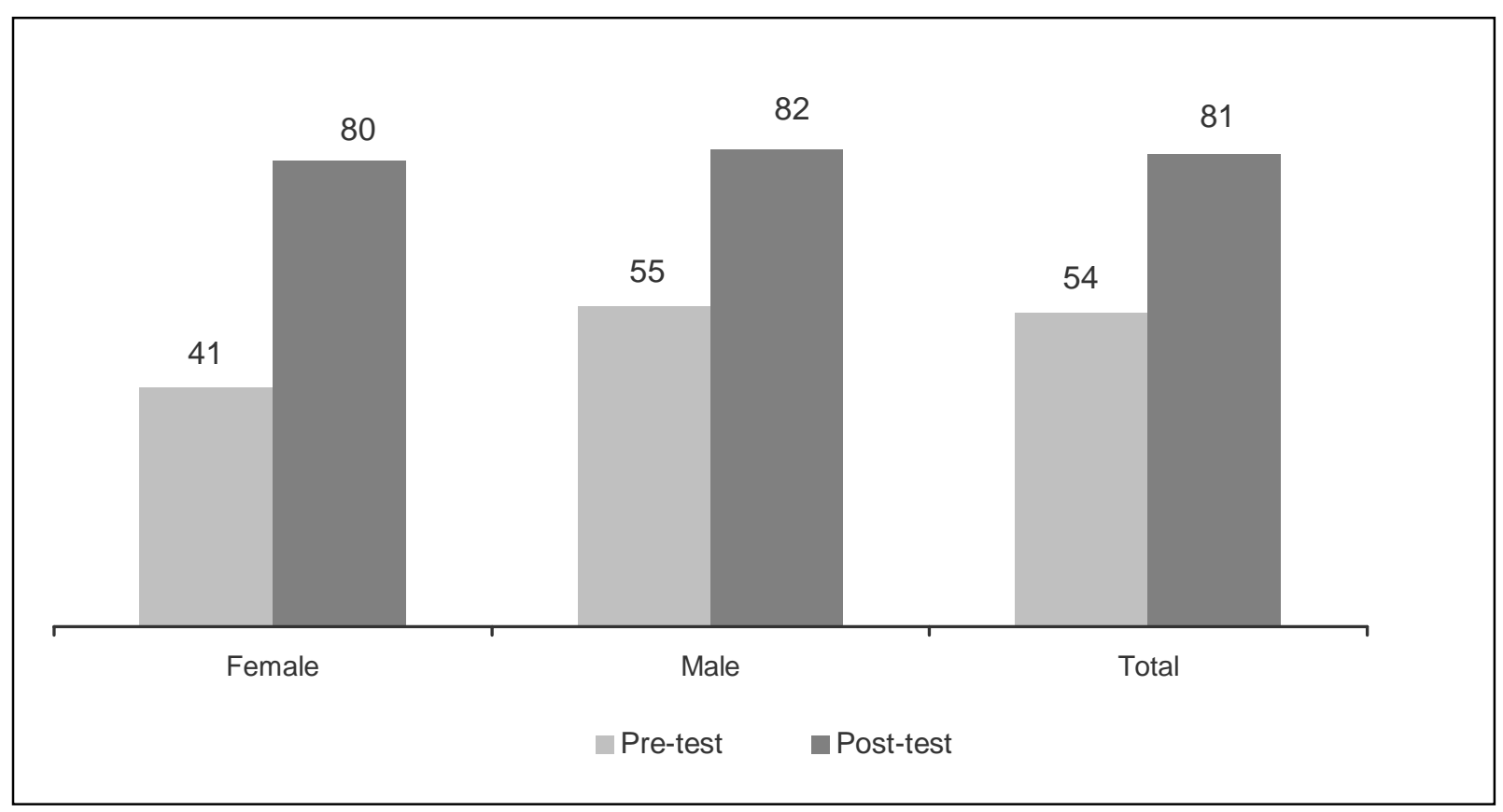

\section{Attitudes towards reproductive health issues}

\section{Belief and perception towards wet dreams, masturbation, menstruation, and menstrual hygiene}

In addition to an increase in knowledge, the reproductive health education also aimed to improve attitudes towards reproductive health issues for subsequent changes in behavior. In order to know attitudes towards reproductive health issues, the respondents were asked if they agreed or disagreed that wet dreams/ejaculation are natural, masturbation is not a bad habit, menstruation is not a disease, and menstrual cloths should be dried in direct sunlight. Young boys' perception of nocturnal emissions are influenced by various beliefs and moral judgments, such as the view that it is a "bad habit" or "fault" (the Bengali word for nocturnal emission, shoponodosh, means dream-fault), which in combination with a lack of information, creates feelings of anxiety and shame. However, the survey revealed that over 80 percent of male respondents already had a positive attitude towards wet dreams, compared to a half of the females who agreed that it is a natural phenomenon for boys (Figure 4 and Table A.9). 
Figure 4. Percent distribution of students on belief and perception towards wet dreams/ejaculation, masturbation, menstruation and menstrual hygiene

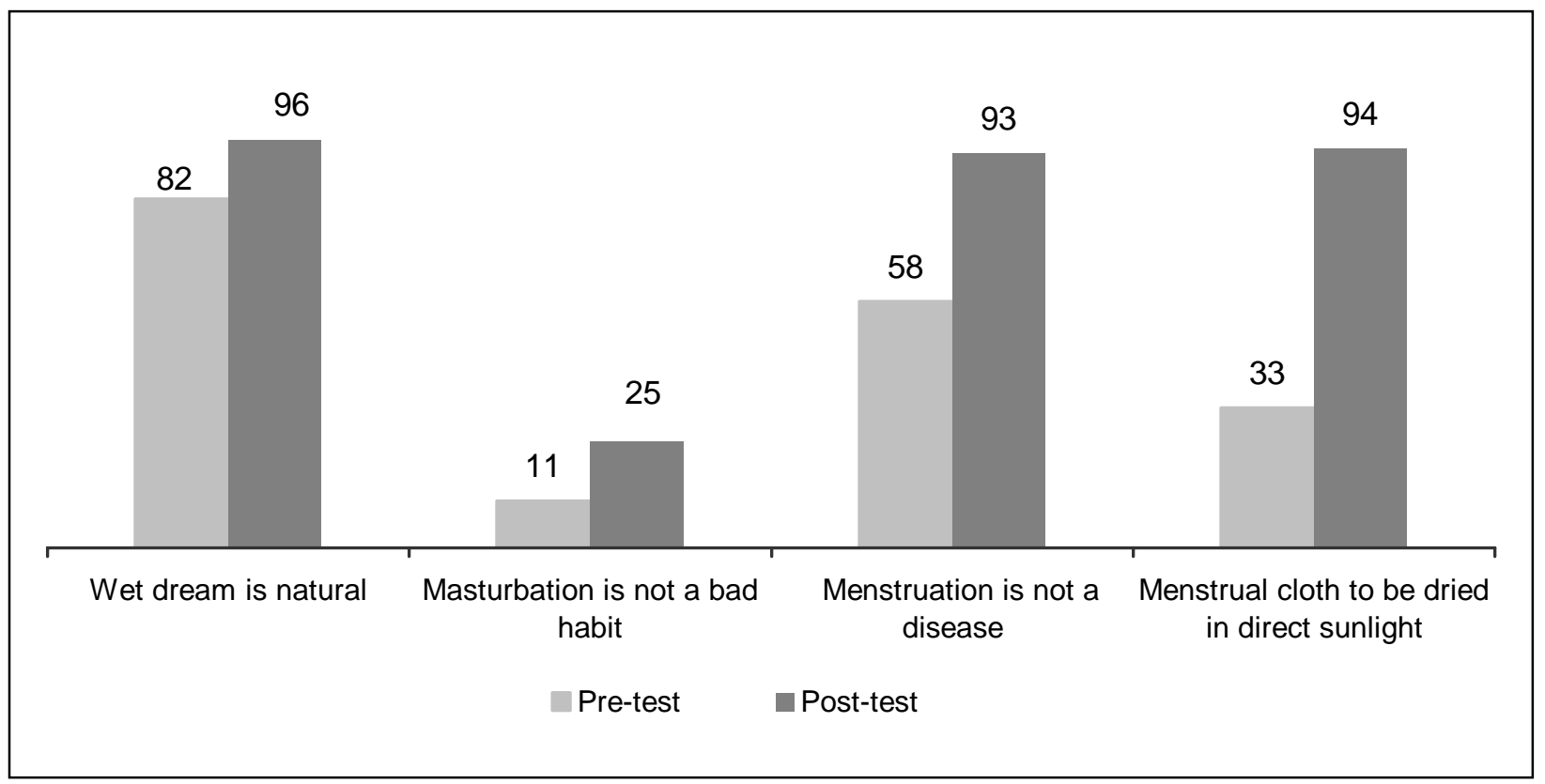

The findings suggest that masturbation is widely believed to be a bad habit. Only 11 percent of respondents reported that masturbation is not a bad habit in pre-test survey, which increased to 25 percent at the final post-test survey (Figure 4 and Table A.9). The increase in positive attitude towards masturbation was significant across age groups for males, and was highest among those less than 20 years old, from 12 to 34 percent. However, it is important to note that despite the reproductive health information, the majority of the students (75\%) did not change their perception of masturbation and continued to believe that it is a harmful habit. This clearly indicates that changing perception is much more difficult than changing knowledge or awareness. The anonymous questions that were put in the question box also indicate the widely held beliefs about the negative consequences of masturbation.

For adolescent girls the lack of prior knowledge about the menstrual cycle may lead to shock at menarche and to the belief that menstruation is a disease. Findings from the pre-test survey revealed that 58 percent of respondents knew that menstruation is not a disease; however, this positive attitude was the lowest (46\%) among the younger respondents. The post-test surveys revealed significant positive improvement to over 90 percent irrespective of sex, with changes greater among younger respondents (Figure 4 and Table A.9).

In a resource poor country like Bangladesh, girls principally use old cloths instead of sanitary pads to control menstrual blood because they can be repeatedly used and are easily available. Managing these old cloths is a major problem due to the taboo attached to menstruation. It is believed that during menstruation a girl is "polluted," can pollute other things as well as people, and at this time they are vulnerable to evil spirits (Huq et al. 1991). Therefore, old cloths are mostly dried in the dark and inconspicuous places so that they are not exposed to others, especially to outsiders and male members of the family. This behavior is due to shame and the belief that others should not know that she is menstruating. The pre-test survey revealed that less 
than one-third of the respondents agreed that menstrual cloths should be dried in direct sunlight, with males being less positive as compared to girls. The positive attitude increased significantly at the post-test survey, and the rate of increase was higher among the younger and male respondents (Figure 4 and Table A.9).

\section{Attitude towards condoms and family planning methods}

Pre-marital sexual exposure is not uncommon in the country and is more pronounced among the boys, especially those who are out of school and working. In order to measure attitudes towards condoms, respondents were asked if they approved of condom use among sexually active young people to prevent STIs and HIV, irrespective of marital status. The pre-test survey showed that 89 percent of respondents were already in favor of condoms, and the approval further increased to 95 percent $(p<0.01)$ in the post-test survey, due to significant change of attitude among the younger and female respondents (Table A.10). Interestingly, respondents were found to be less favorable towards the use of family planning methods to prevent pregnancy as compared to the use of condoms to prevent STIs. Approval rates increased from 68 to 84 percent $(p<0.01)$ at the post-test.

\section{Reproductive health life skills}

In the reproductive health sessions, information was imparted to enhance the critical thinking skills of students and to enable them to make rational decisions and to negotiate to avoid peer and media pressure. In order to understand the decisionmaking skill in case of sexual abuse, the respondents were asked what to do if an older relative touches someone inappropriately. Pre- and post-test surveys indicated a significant increase in the positive decisions to inform parents and keep away from the abuser, while harmful decisions like to keep quiet and to feel ashamed significantly decreased (Figure 5). The decision to inform parents increased significantly among the females from 39 to 67 percent (Table A.11).

Figure 5. Percent distribution of students on decisionmaking skills in case of sexual abuse (multiple responses)

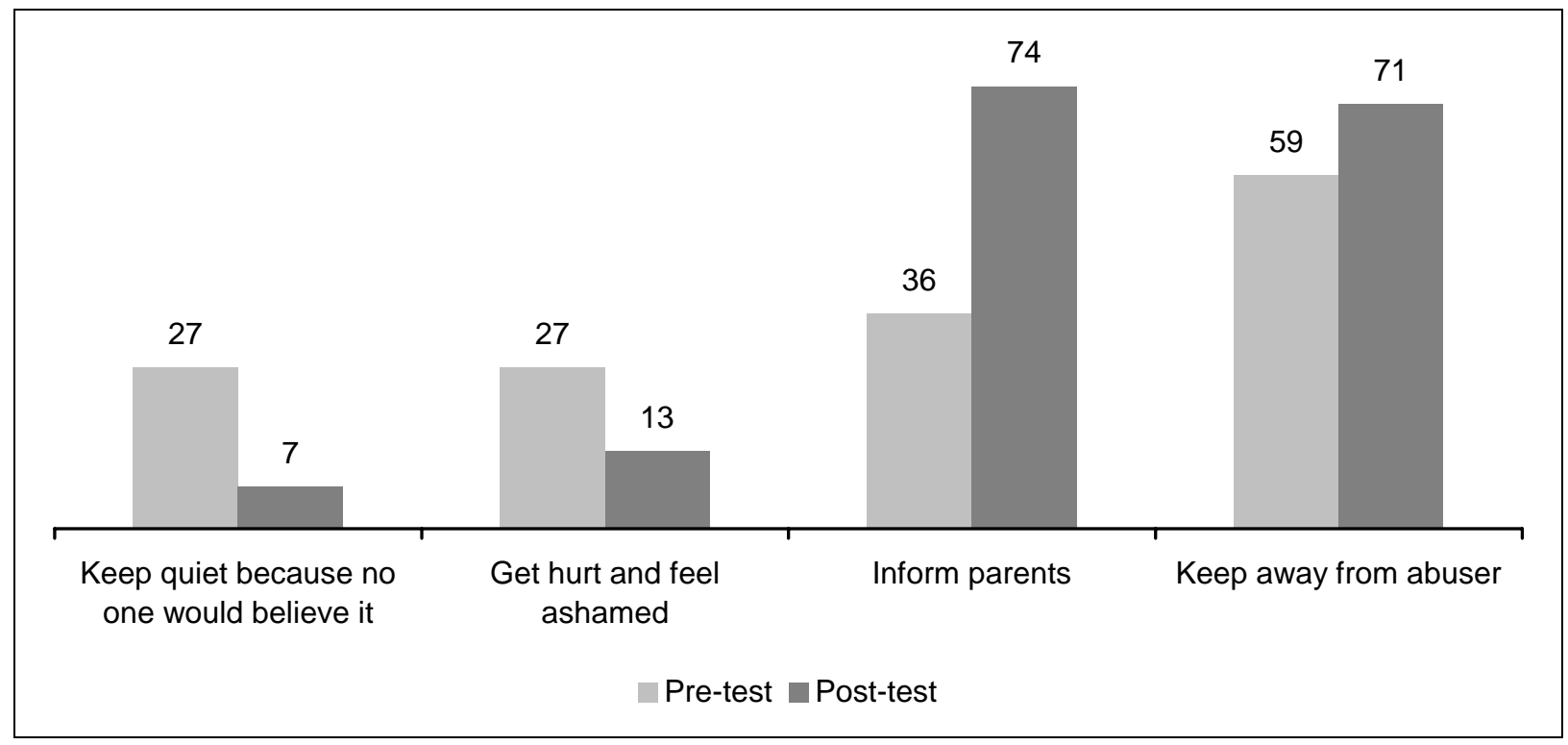


In order to understand negotiation skills, the respondents were asked what they would do or what a girlfriend should do in case a boyfriend wants to initiate sex. As per the country's sociocultural and religious background, pre-marital sex is not accepted. Following the value system, reproductive health education also emphasized abstinence and disapproved of pre-marital sex. The findings show that the reproductive health course helped them to understand the options in such a situation; for instance, a significantly higher number of respondents in the post-test survey reported that the girlfriend should request the boyfriend to wait until marriage. Agreeing to consent to sex subject on the condition of using condoms significantly decreased among males in the post-test survey (39 to 24\%) (Figure 6 and Table A.12).

Figure 6. Percent distribution of students on negotiation skills in case a boyfriend wants to initiate sex (multiple responses)

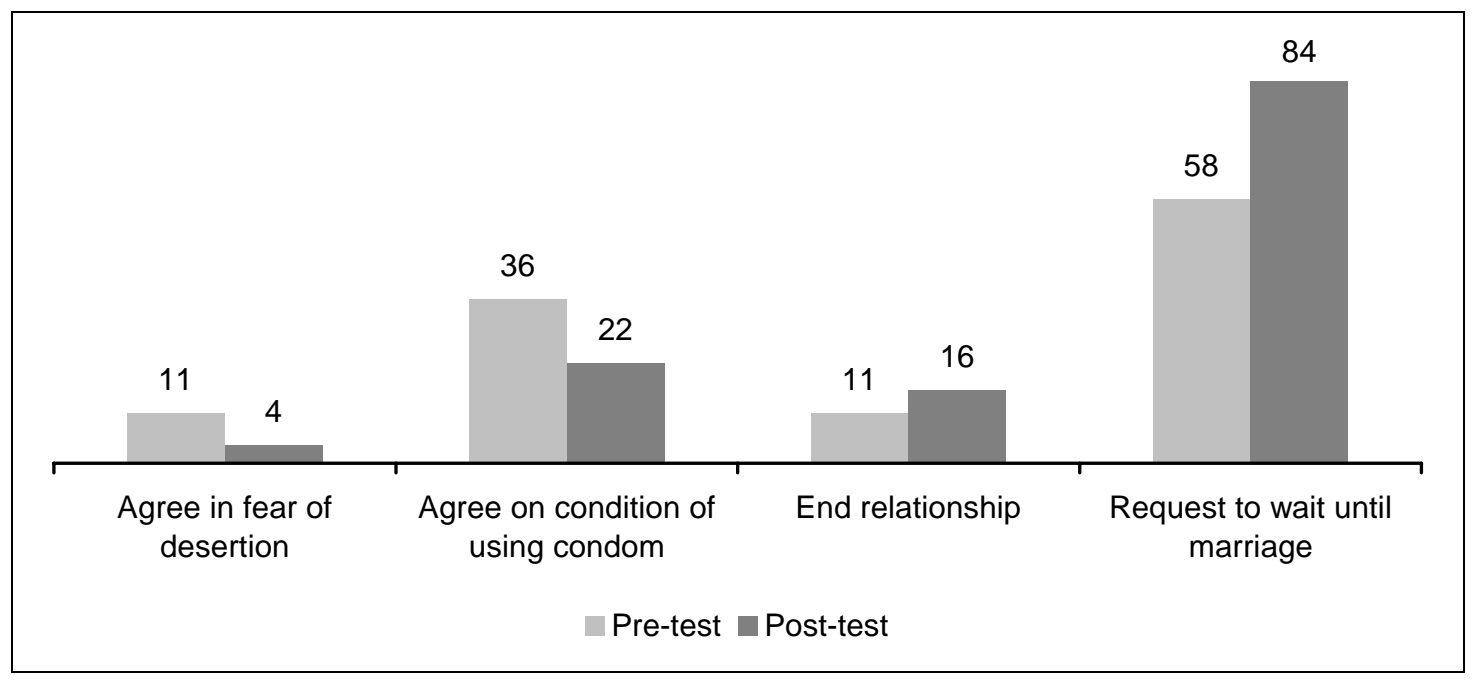

To measure the critical thinking skills to avert media and peer pressure, the respondents were asked if they would agree, disagree, or remain indecisive with a youth: (i) who smokes like a favorite actor, (ii) who refuses drugs from friends, even if they are free, because substance abuse is bad for their health and, (iii) who accompanies a friend in visiting commercial sex workers (CSWs) because the friend is afraid to go alone.

The findings show that in all the three cases, a majority (74 to 88\%) of the students during the pre-test chose appropriate and correct responses indicating the need for avoiding peer pressure or media influence. The reproductive health course helped them in strengthening these critical thinking skills, and the percentage of such students expressing correct choices significantly increased up to 97 percent (Figure 7 and Table A.13). 
Figure 7. Percent distribution of students on critical thinking skills to avert media

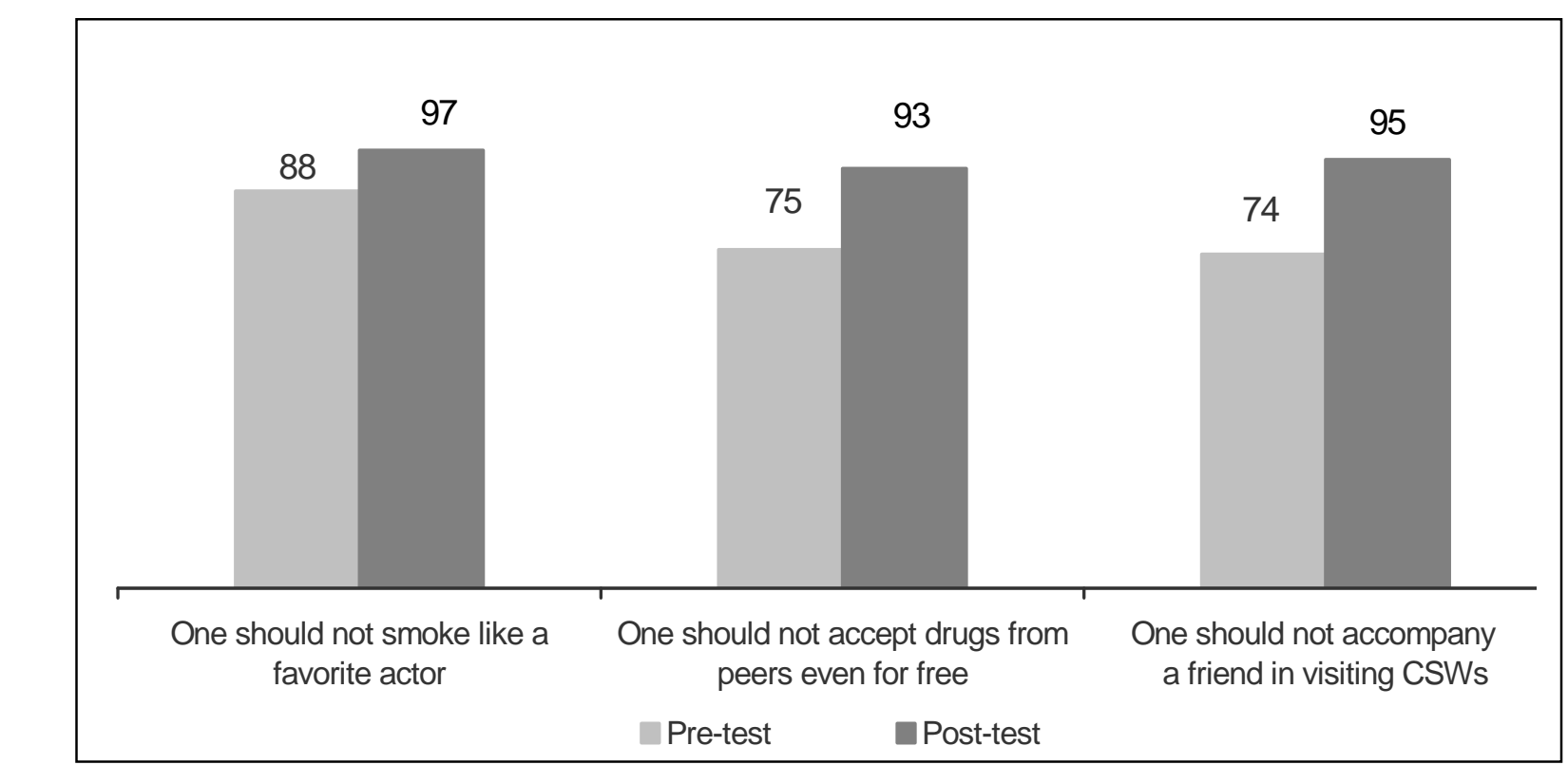

influence and peer pressure

\section{Reproductive health education in training courses}

The pre-test survey revealed that almost all students approved of reproductive health education for young persons as it would help them to prevent STIs and HIV (93\%) and enable young persons to avert substance abuse and unintended pregnancy (84\%). The other reasons included enabling young persons to avert peer and media pressure (28\%), and counseling peers to avert risk behaviors (3\%) (not shown). Only six percent of respondents in the pre-test survey and one percent in the post-test survey believed that reproductive health education would make young persons insubordinate to parents and teachers and influence them to initiate sexual activity earlier.

Informal discussions with the students revealed that many thought they had greatly benefited from the reproductive health sessions.

"I used to go to hotels in Mymensingh with my friends to visit commercial sex workers. We used to go by train and it didn't cost much. After attending the reproductive health sessions, I've stopped it. Whenever the thought of going to commercial sex workers came to my mind, I restrained myself.”

A 20-year old unmarried male

"I was worried about having wet dreams thrice a week, as we know that loosing dhatu (semen) is very bad for health. After having wet dreams, I also didn't use to change my lungi (a traditional male dress) because of shame (the intent was not to let other people know because wet dreams are believed to happen due to thinking about sex, which is not a socially acceptable behavior for an unmarried young person). After attending the classes, I'm neither ashamed nor worried about it." 
"Earlier I believed that during menstruation one should not eat eggs or drink milk because that would cause white leprosy. But now I know that these are misconceptions and there is no shame to have menstruation. All females, including my mom and aunts, experience menstruation-so why should I feel ashamed of it? From now on, I would always dry the menstrual cloths in direct sunlight. ”

\section{A 21-year old unmarried female}

"I didn't know how to say NO to my friends, so I used to hang around and listen to them even if I didn't want to. For instance, I spent time with them when I wanted to study. Once they made me eat tablets that caused me to sleep day and night. But this time when I went home on vacation, I could avoid them by making excuses. I'm also trying to dispel stigma attached to menstruation, pregnancy and newborn babies. In my village, it is said that during pregnancy one cannot eat mrigifish (a kind of fresh water fish that looks much like a serpent) because the fish would make the stomach twist. The newborn baby's mother is also considered impure and both the mother and the child are kept in a separate room for 40 days. Now, I know that these are mere misconceptions and I've started asking questions about these practices at home.”

An 18-year old unmarried female

\section{Evaluation of teachers who imparted reproductive health education}

The trained teachers were the most important factor in implementing the curriculum and conducting reproductive health sessions. For this reason, the teachers' performance was evaluated during the training of trainers (TOT), follow-up visits, and post-test surveys. Pre- and post-tests conducted during the TOT revealed that all the participating teachers were supportive of education for youth on reproductive health, HIV and AIDS, and gender. They also unanimously believed that such training should be incorporated into the regular Department of Youth Development training curriculum. Teachers were interested in conducting reproductive health sessions, but half of the respondents said that they would feel discomfort and/or be shy. The primary barrier for a teacher to discuss reproductive health education was discomfort with reproductive organs and condoms, which they believed to be a taboo item for discussion with the students. Three of the teachers overcame their shyness after the training. In-depth interviews revealed that two unmarried teachers, one female and one male, remained shy only in discussing the use and benefits of condoms. Another trained teacher came to the assistance of the female teacher while the male teacher overcame his shyness by using the appropriate language in the curriculum and creating an enabling environment with an emphasis on the cultural value system. 
Table 9. Distribution of teachers according to selected topics

\begin{tabular}{|c|c|c|c|c|}
\hline \multirow[t]{2}{*}{ Issues } & \multicolumn{2}{|c|}{ Pre-test } & \multicolumn{2}{|c|}{ Post-test } \\
\hline & Yes & No & Yes & No \\
\hline $\begin{array}{l}\text { Agreed to reproductive health education for } \\
\text { young people }\end{array}$ & 10 & - & 10 & - \\
\hline $\begin{array}{l}\text { Agreed to incorporation of reproductive health } \\
\text { education to Department of Youth } \\
\text { Development training courses }\end{array}$ & 10 & - & 10 & - \\
\hline $\begin{array}{l}\text { Expressed that s/he would be interested to } \\
\text { impart reproductive health education to young } \\
\text { people }\end{array}$ & 10 & - & 10 & - \\
\hline $\begin{array}{l}\text { Perceived that s/he would feel comfortable to } \\
\text { impart reproductive health education to young } \\
\text { people }\end{array}$ & 8 & 2 & 10 & - \\
\hline $\begin{array}{l}\text { Expressed that s/he would feel shy in } \\
\text { imparting reproductive health education to } \\
\text { young people }\end{array}$ & 5 & 5 & 2 & 8 \\
\hline $\mathrm{N}$ & 10 & 10 & 10 & 10 \\
\hline
\end{tabular}

During practice sessions of the TOT, each teacher conducted a half-hour practice session, following which they received feedback on the strengths and weaknesses of their performance. Facilitators as well as participating teachers evaluated the participants' performance by filling in a total of 116 evaluation forms, which were analyzed to find out the participants' level of reproductive health knowledge, friendliness and facilitation skills including use of material and methods, timeliness, body language, use of appropriate language, and confidence (Annex $\mathrm{C}$ and Table A.15). A total of 10 indicators were used, each with 5 to 15 points. The varying marks showed the relative importance of an indicator. For instance, the presentation of the curriculum contents was worth 15 points, while the use of training materials was 5 points. Some of the strengths and weaknesses of the teachers as identified in the TOT are presented in following table (Table 10).

The 10 facilitators received an average mark of 72 out of 100 with a standard deviation of 4.6. The self-evaluation of the trainers is important, but this also seemed to bias the performance matrix. As the checklists were filled out anonymously, the self-evaluations could not be excluded from the analysis. Most teachers received quite satisfactory scores (Figure 8). 
Table 10. Strengths and weaknesses of the teachers identified during the training of trainers

\begin{tabular}{|c|c|}
\hline Strengths & Weaknesses \\
\hline $\begin{array}{l}\text { Successfully included participants into } \\
\text { discussion, appreciated the responses } \\
\text { made by the participants, and treated them } \\
\text { with respect. } \\
\text { - Use of appropriate body language, e.g., } \\
\text { eye contact with participants, use of hands, } \\
\text { changed position and voice. } \\
\text { - Used overhead projector appropriately, } \\
\text { covered portion of the transparency sheet } \\
\text { to focus on the issue at the point of } \\
\text { discussion. }\end{array}$ & $\begin{array}{l}\text { - Asked too many questions using the name of } \\
\text { the participant. } \\
\text { - Inappropriate use of the overhead projector by } \\
\text { shadowing the screen or not explaining the } \\
\text { contents. } \\
\text { - Not summarizing the stories and asking } \\
\text { relevant questions before leading to the } \\
\text { contents. } \\
\text { - Not summarizing the session or not seeking } \\
\text { feedback from the participants. } \\
\text { - Improper time and class management. }\end{array}$ \\
\hline
\end{tabular}

Figure 8. Teachers' capacity in delivering reproductive health education during practice sessions of the training of trainers (\%)

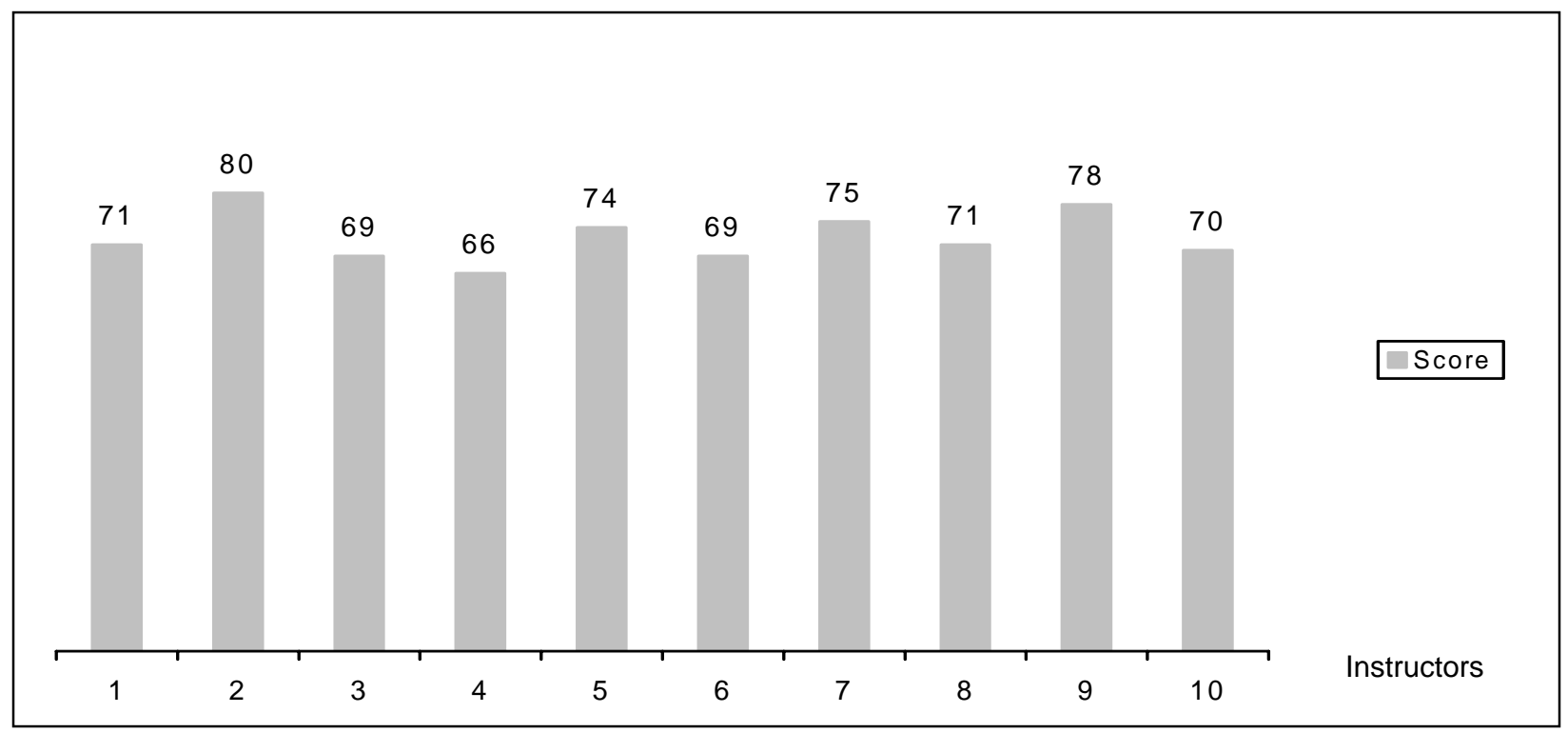

Students also evaluated the capacity of teachers to impart reproductive health education in the post-test survey. Results showed that the teachers had sufficient knowledge, explained the subject matter clearly, and discussed the role of condoms in preventing STIs and HIV. However, about one-tenth of the students reported that teachers were judgmental and unfriendly (Figure 9 and Table A.16). 
Figure 9. Teachers' ability to conduct reproductive health sessions as reported by the students

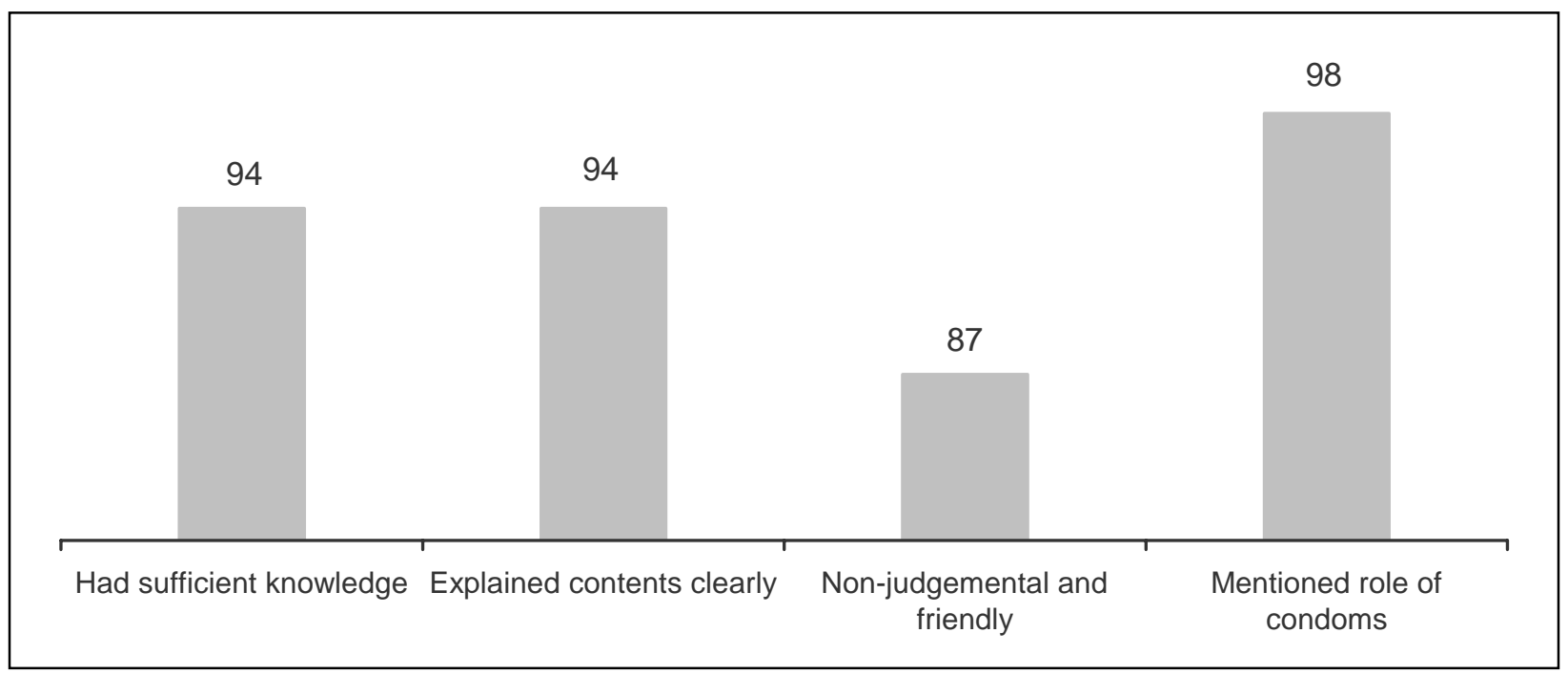

The focus group discussions and in-depth interviews with students revealed key strengths and weaknesses of the teachers from the students' perspective (Table 11).

Table 11. Strengths and weaknesses of the teachers from the students' perspective

\begin{tabular}{|c|c|}
\hline Strengths & Weaknesses \\
\hline 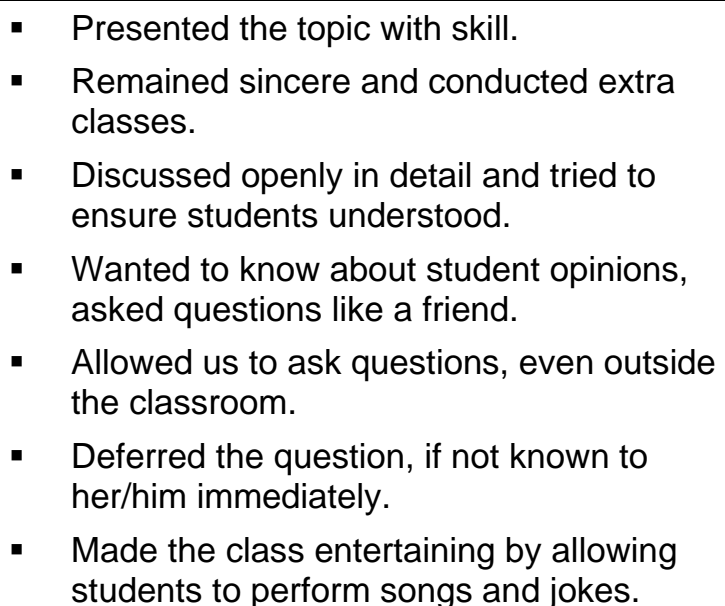 & $\begin{array}{l}\text { Not discussing everything elaborately, } \\
\text { especially due to lack of time. } \\
\text { - Not frank enough and emphasized keeping } \\
\text { distance from students. } \\
\text { Unfriendly because the teacher(s) continued } \\
\text { the class for extended hours, did not allow } \\
\text { students in the class after starting the session, } \\
\text { and only allowed a limited number of } \\
\text { questions. } \\
\text { - Scolded some of the students in the class. }\end{array}$ \\
\hline
\end{tabular}

Discussions with the teachers revealed that managing a class with an average number of 60 students sometimes prevented teachers from friendly behavior. In addition, some of the students were unruly, and tended to take advantage of the friendly behavior of the teachers. Thus, some teachers faced the constant dilemma of managing the class using both the traditional authoritarian practice and the non-judgmental and friendly behavior recommended by the reproductive health curriculum. 


\section{Obstacles faced and strategies to overcome the barriers}

In focus group discussions and in-depth interviews, teachers and students revealed several obstacles faced in conducting and receiving reproductive health education. The obstacles faced and the strategies employed to overcome the barriers are depicted below in Table 12.

Table 12. Obstacles faced and strategies to overcome the barriers of reproductive health education

\begin{tabular}{|c|c|c|}
\hline & Obstacles & Strategies to overcome barriers \\
\hline \multirow[t]{4}{*}{ Students } & $\begin{array}{l}\text { - Students initially did not have any } \\
\text { handouts. }\end{array}$ & $\begin{array}{l}\text { - Reading materials were provided for better } \\
\text { internalization and group discussions. }\end{array}$ \\
\hline & $\begin{array}{l}\text { Due to leave and religious } \\
\text { holidays, every student could not } \\
\text { attend all the sessions. }\end{array}$ & $\begin{array}{l}\text { - The topic was covered in discussion with the } \\
\text { classmates and by consulting the reading } \\
\text { materials. }\end{array}$ \\
\hline & $\begin{array}{l}\text { - Female students were shy to } \\
\text { actively participate in discussions. }\end{array}$ & $\begin{array}{l}\text { - Encouragement from teachers and friendly } \\
\text { behavior of male students influenced females } \\
\text { to participate in discussions. }\end{array}$ \\
\hline & $\begin{array}{l}\text { - Students in one institution were } \\
\text { uncomfortable because they } \\
\text { thought participating in } \\
\text { reproductive health sessions } \\
\text { during the holy month would repeal } \\
\text { fasting. }\end{array}$ & $\begin{array}{l}\text { - When teachers explained the reasons when } \\
\text { fasting is repealed, then the students became } \\
\text { comfortable in attending the reproductive } \\
\text { health sessions. }\end{array}$ \\
\hline \multirow[t]{3}{*}{ Teachers } & $\begin{array}{l}\text { - There were no overhead projectors } \\
\text { or microphones in two institutions. }\end{array}$ & $\begin{array}{l}\text { - Initially overhead projectors were borrowed } \\
\text { from other governmental institutions; later both } \\
\text { the centers received instruments from } \\
\text { Department of Youth Development } \\
\text { headquarters. }\end{array}$ \\
\hline & $\begin{array}{l}\text { - With average class size of seventy } \\
\text { students, two topics could not be } \\
\text { covered within the allotted time. }\end{array}$ & $\begin{array}{l}\text { - Extra and extended classes were conducted in } \\
\text { consultation with the students. }\end{array}$ \\
\hline & $\begin{array}{l}\text { - Not having immediate answers to } \\
\text { every question. }\end{array}$ & $\begin{array}{l}\text { - Teachers deferred questions, consulted with } \\
\text { supplementing materials and/or Population } \\
\text { Council staff, and advised students with } \\
\text { medical questions to visit a health facility. }\end{array}$ \\
\hline
\end{tabular}




\section{UTILIZATION}

To share the findings, a national level dissemination seminar was organized in March 2005 in Dhaka. About a hundred officials representing the Department of Youth Development and the Ministry of the Youth and Sports, the Directorate General of Family Planning, the National Curriculum and Textbook Board, various NGOs, and development partners attended the seminar. Through group discussions, participants proposed to scale up the curriculum to the rest of the residential and non-residential Department of Youth Development training institutions. The Director General of the

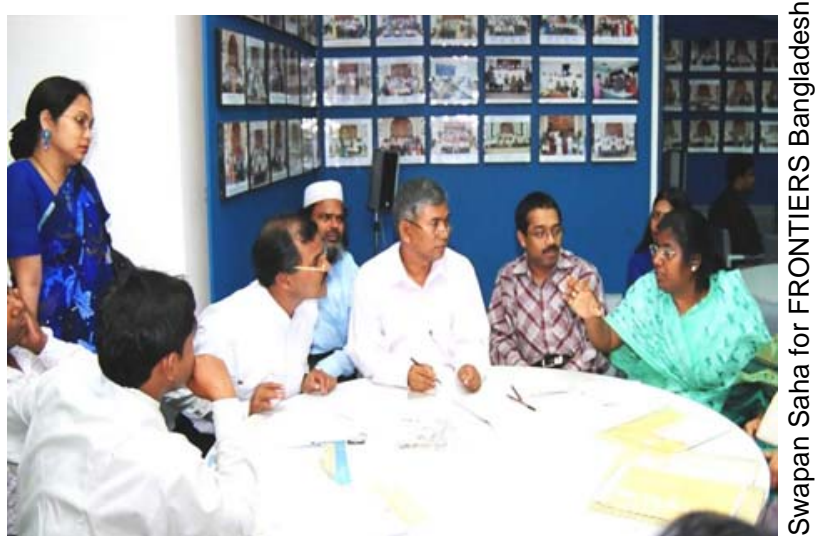

Interactive group discussions in the dissemination seminar.

Department of Youth Development requested

technical assistance from the Population Council to replicate the reproductive health education course in the rest of the residential and non-residential training institutions (Annex D).

The Population Council provided technical assistance to scale up the reproductive health education in the remaining 42 residential Youth Training Centers. Pending funding, the curriculum will also be introduced in the remaining non-residential training institutions of the Department of Youth Development. Training for selected Department of Youth Development officials of the 42 youth centers began in September 2005 with two four-day training of trainers' sessions, versus the five-day training of trainers in the pilot. The training was jointly coordinated with the Department of Youth Development, and the Deputy Director of Training was present for all sessions. To accompany the training, the trainees were given a reproductive health manual, transparencies, question boxes, story leafs, banners, and attendance registers. Two trained teachers from the pilot institutions also attended the training to share their experiences with implementation of the reproductive health curriculum.

At the end of the training, in consultation with the Deputy Director of Training, the participants developed implementation plans to start conducting sessions with the students who would enroll in the Youth Training Centers for the academic period of October-December 2005. The teachers also agreed to start the reproductive health sessions one month after student enrollment so that they would be able to build rapport with the students before introducing sensitive topics. The participants of the training of trainers evaluated the training as useful because of the participatory and interactive methodology and the materials.

In order to measure the changes in the knowledge, skills, and attitudes of the trainees, pre- and post-tests were employed. In addition, performance in the practicum sessions was evaluated using facilitation observation checklists. The average score of the forty participants was 64 out of 100 with a standard deviation of 5 . The average score was less than that of the pilot institutions (72 out of 100), perhaps due to the fact that the number of participants in each session was twice as large as that in the pilot sessions or that they had one less day of training than the pilot institutions had. The teachers of the Youth Training Centers were observed to be enthusiastic and competent to implement the reproductive health sessions. Their strong points included 
explanatory presentations, confidence, friendly and non-judgmental behavior. The weak points of the teachers were inadequacy in taking feedback, inefficient time management, and improper use of the overhead projector. Both strong and weak points of the trainees were discussed in review sessions so that they could improve their performance.

To reinforce the reproductive health facilitation capacity, both trainees and facilitators underscored the need for refresher training/workshop within six months, when the teaching staff of the Department of Youth Development would finish teaching the course to two batches of youth.

\section{CONCLUSIONS AND RECOMMENDATIONS}

Building a knowledge base on reproductive health issues and using participatory methods of teaching takes time and practice. Practice sessions were the best feature of the training of trainers. However, due to time constraints, it was not possible for the participants to practice all of the sessions. In addition to the training of trainers, participants found the curriculum, transparencies, and question boxes to be the most useful in the implementation of the reproductive health education.

The process of obtaining informed consent and the confidentiality of the pre- and post-tests created a good impression about the method of data collection among both the students and teachers. The pre-test survey also served as a facilitating factor in setting the stage for teachers to initiate the reproductive health curriculum. The sensitization meetings with the peer teachers were also helpful in securing their support. The most important aspect of introducing the reproductive health curriculum was the permission and support of Department of Youth Development headquarters.

In teaching the reproductive health education course, teachers were inundated with many questions that they did not have answers for, as they required responses from a qualified medical provider. Among the contents of the curriculum, the topic on life skills was difficult to grasp. Advocacy for the reproductive health session was also found to need elaborate discussion as to why the young people should know about condoms. Teachers varied in asking about feedback to evaluate the session. A set of questions at the end of every topic could help teachers to focus on the key issues. The monitoring visit was a facilitating factor that created enthusiasm among the teachers and students. However, the close monitoring revealed that some of the teachers continued making the same mistakes as they had during the practical sessions of the training of trainers.

Some of the teachers conducted informal counseling sessions but did not ensure privacy. A few of the teachers were also found to have the dilemma of trading off between the traditional authoritarian practice in managing the class versus the non-judgmental and friendly behavior recommended in teaching the reproductive health curriculum. Individual copies of the reading materials were not supplied to the students, which created a fear of loss of newly gained knowledge. Due to lack of functioning equipment, the CDs remained unused.

The overall findings of the study show that the reproductive health education increased both the knowledge and life skills of the youth, and created positive changes in attitudes: 
- Knowledge about the physical changes during adolescence increased from 64 percent at the pre-test to over 95 percent at the post-test. Awareness about the fertile period, the time during the month a woman is most likely to get pregnant if she has sexual relations, increased significantly, almost doubling at the post-test from the level at the pre-test. Knowledge about the IUD and implants almost tripled, 30 to 95 percent. Almost all respondents (97\%) had heard about condoms, however, less than two-thirds of them knew about the dual protection of condoms (prevention of pregnancy and STIs) at the pre-test. After the reproductive health education course, this figure increased significantly to 89 percent at the post-test. The percentage of respondents who had heard about emergency contraceptive pills (ECP) increased from 42 to 93 after the course, and two-thirds of respondents could mention the reasons for the use of ECP.

- Misunderstandings about the role of the mother in determining the sex of a child were substantially dispelled. Awareness that only the father, or the chromosome of the father, determines the sex of a child increased three-fold, from 26 to 76 percent. Misconceptions about routes of transmission of sexually transmitted infections (STIs) decreased by over 30 percent, and awareness about the need to continue taking medicine even when the symptoms of the STI disappear doubled to 80 percent. Knowledge about ways to prevent HIV also improved, and the highest increase was on the negotiation of safe sex (53 to $83 \%)$.

- After being exposed to the reproductive health course, the number of youth who do not consider menstruation a disease nearly doubled (from 58 to 93\%). In addition, the number of the respondents who knew that menstrual cloths should be dried in direct sunlight nearly tripled (from 33 to 94\%).

- Youth have also become more skilled in avoiding pre-marital sex, sexual and substance abuse. For avoiding pre-marital sex, a significantly higher number of respondents (from 58 to $84 \%$ ) reported that the girlfriend should request the boyfriend to wait until marriage. Significant positive improvement was seen in averting peer pressure to visit commercial sex workers. Similarly, positive attitudes were observed for ignoring media influence on substance abuse.

Results also revealed that both the training of trainers and the training materials provided enabled teachers to effectively impart reproductive health education. Over 95 percent of students reported that teachers had sufficient knowledge of the topics, explained the subject matter clearly, and discussed the role of condoms. Only about one-tenth of them reported that the teachers were judgmental and unfriendly.

In order to ensure efficient utilization of limited resources, it was recommended that the curriculum be extended to the remaining residential and non-residential training institutions of the Department of Youth Development. The Director General of the Department of Youth Development endorsed these recommendations and requested technical assistance from the Population Council. Participants in the dissemination seminar also suggested scaling up the curriculum to other institutions. The Population Council provided technical assistance to scale up the reproductive health education in the remaining 42 residential Youth Training Centers. 
Pending funding, the curriculum will also be introduced in the remaining non-residential training institutions of the Department of Youth Development. To further improve the training and replication of the reproductive health education in other training centers, the following recommendations are made:

- The teacher curriculum needs to be revised to incorporate a section on facilitation skills with examples of the key errors made in handling materials and in imparting the reproductive health education. Since the reproductive health teachers conduct informal counseling sessions, a sub-section on counseling would be helpful. Moreover, the traditional authoritarian practice in managing the class versus the non-judgmental and friendly behavior recommended by the curriculum needs to be discussed in-depth. A chapter on the most frequently asked questions with responses, if supplemented to the curriculum, would help both teachers and students to have a deeper understanding of the reproductive health issues. Among the contents of the curriculum, the topic on life skills needs to be simplified with multiple examples, while advocacy for the reproductive health session needs to build a stronger case as to why young people should know about condoms and emergency contraceptive pills. A set of questions at the end of every topic could usefully serve either as a tool to get feedback on the session or as a pre- and post-test questionnaire.

- Students' reading materials should contain more illustrations and stories. A set of questions at the end of every topic would also help students in self-evaluation. Students also need to receive individual copies of reading materials. For further dissemination of the knowledge in the community, students could also be given a set of flash cards or pamphlets containing stories, visuals, and key messages.

- Posters can be developed and hung in different locations on the campus to support key messages. Visual transparency sheets should have color photos, and posters can supplement them.

- To build a higher degree of competent teachers, the five-day training of trainers model should be kept versus the four-day model used in the scale up. Experience from the scale up suggests that the shorter duration was not as effective. At the end of the implementation of the reproductive health curriculum, it would be helpful to organize a workshop among the teachers to discus the problems faced and strategies used to facilitate the teaching. Due to the large class size, with an average of 63 students, the curriculum needs to be extended from the current 10 hours to 12 hours. Female students should be encouraged to participate in the reproductive health sessions.

- Training institutions should also invite a physician to respond to the anonymous questions posed by the students regarding RTI/STI-related conditions. Linkages between the students and the health facility as well as organizations that provide support services for violence against women and substance abuse also need to be established.

- In continuing with the reproductive health education, it is imperative to ensure monitoring and follow-up support to teachers. A regular monitoring team consisting of personnel from Department of Youth Development headquarters and a third party would keep the spirit up of both the students and teachers. 


\section{REFERENCES}

Amin, Sajeda, Simeen Mahmud, and Lopita Huq. 2002. Kishori Abhijan: Baseline Survey Report on Rural Adolescents in Bangladesh. Dhaka: Department of Women's Affairs, Ministry of Women and Children Affairs, Government of the People's Republic of Bangladesh.

Baatsen, Pam. 2003. "Brothel based sex work in Bangladesh: Data from fourth round secondgeneration surveillance," presentation at the Dissemination Seminar on Epidemiology \& Etiology of STIs among Brothel-Based Sex Workers in Bangladesh organized by the International Centre for Diarrhoeal Diseases Research, Bangladesh (ICDDR,B), Dhaka. 13 July.

Bangladesh Bureau of Educational Information and Statistics, Ministry of Education. 2003. "Bangladesh Educational Statistics 2003.” Dhaka: Habib Press Limited.

Barkat Abul, Sayeedul Haque Khan, Murtaza Majid, and Nazme Sabina. 2000. "Adolescent Sexual and Reproductive Health in Bangladesh: A Needs Assessment.” Dhaka: International Planned Parenthood Federation and Family Planning Association of Bangladesh.

Bhuiya, Ismat. 2005. "Scaling up of Interventions," presentation at the Dissemination Seminar of Population Council's FRONTIERS Program and Department of Youth Development, Ministry of Youth and Sports, Government of the People’s Republic of Bangladesh, Dhaka, 23 March.

Bhuiya, Ismat, Ubaidur Rob, M. E. Khan, and Ahmed Al Kabir. 2004. "Reproductive health services for adolescents: recent experiences from a pilot project in Bangladesh," in Sarah Bott, Shireen Jeejeebhoy, Iqbal Shah and Chander Puri (eds.), Towards Adulthood: Exploring the Sexual and Reproductive Health of Adolescents in South Asia. Geneva: WHO, pp. 203-206.

Bhuiya, Ismat, Ubaidur Rob, M.E. Khan, Laila Rahman, and Asiful H. Chowdhury. 2003. "Unmarried Adolescent Boys' Vulnerability Towards HIV/AIDS in Bangladesh," presentation at the $131^{\text {st }}$ Annual Meeting and Exposition of the American Public Health Association, San Francisco, 17-18 November.

2003. "Effectiveness of Linking Schools with Sexual and Reproductive Health Services: Experiences from a Pilot Project in Bangladesh," presentation at the $131^{\text {st }}$ Annual Meeting and Exposition of the American Public Health Association, San Francisco, 17-18 November.

. 2003. "Strategies to Improve Reproductive Health of Adolescent Girls in Bangladesh: Experiences from a Pilot Project," presentation at the $131^{\text {st }}$ Annual Meeting and Exposition of the American Public Health Association, San Francisco, 17-18 November.

Bhuiya, Ismat, Ubaidur Rob, Laila Rahman, and Asiful H. Chowdhury. 2003. "Adolescent Reproductive Health Need: Findings from an Operations Research Study," presentation at the Workshop on Translating Research Findings into Action: Experiences from Bangladesh of the Population Council's FRONTIERS Program, Dhaka, 17 June. 
Bhuiya, Ismat, Ubaidur Rob, Susan Adamchak, Laila Rahman and Asiful H. Chowdhury. 2003. "Improving Adolescents' Sexual and Reproductive Health: Experiences from an Operations Research Project," presentation at the Dissemination Seminar on Adolescents Sexual and Reproductive Health of the FRONTIERS Program of the Population Council, Dhaka, 20 January.

. 2003. "Adolescent Reproductive Health: Findings from an Intervention Research: Youth Reproductive Health and HIV Prevention," presentation at the Conference on New Findings from Intervention Research: Youth Reproductive Health and HIV Prevention, Washington D.C., 9-10 September.

Bhuiya, Ismat. 2002. "Situation of Sex Education in Bangladesh," presentation at the Workshop on Sex Education in Bangladesh of the South-South Center, Dhaka, 24 December.

Bhuiya, Ismat, Ubaidur Rob, and M. E. Khan. 2002. "Challenges in Creating AdolescentFriendly Reproductive Health Environment in Bangladesh,” presentation at the XIV International AIDS Conference, Barcelona, 7-12 July.

Bhuiya, Ismat, Ubaidur Rob, M. E. Khan, and Laila Rahman. 2002. "Developing and Introducing a School Curriculum on Sexuality: A Challenge," presentation at the $130^{\text {th }}$ Annual Meeting and Exposition of American Public Health Association, Philadelphia, 9-13 November.

Bhuiya, Ismat, Ubaidur Rob, and M. E. Khan. 2001. “Adolescents and Sexuality in Bangladesh,” presentation at the $129^{\text {th }}$ Annual Meeting and Exposition of American Public Health Association, Atlanta, 21-25 October.

. 2001. "Sex education in secondary schools: Lessons learned from a pilot project in Bangladesh,” presentation at the $129^{\text {th }}$ Annual Meeting and Exposition of American Public Health Association, Atlanta, 21-25 October.

Bhuiya, Ismat, Ubaidur Rob, M. E. Khan, and Ahmed Al Kabir. 2001. "Bridging Sexual Health Knowledge Gap among Adolescents: Protecting Millions from HIV/AIDS in Bangladesh,” presentation at the Sixth Congress on AIDS in Asia and the Pacific, Melbourne, 5-10 October.

Department of Youth Development. 2003. "National Youth Day 2003: Youth will build the country braving the sufferings and pains." Dhaka: Department of Youth Development, Ministry of Youth and Sports, Government of the People’s Republic of Bangladesh.

Haider, Sayed Jahangir, Shamsun Nehar Saleh, Nahid Kamal, and Alan Gray. 1997. "Study of adolescents: Dynamics of perception, attitude, knowledge and use of reproductive health care.” Dhaka: Population Council.

Huq, N. and M. R. Khan. 1991. "Menstruation: Beliefs and practices of adolescent girls.” Dhaka: BRAC.

Kabir, Rachel. 2002. “Adolescent Boys in Bangladesh.” Dhaka: UNICEF Bangladesh Country Office.

1999. “Adolescent Girls in Bangladesh.” Dhaka: UNICEF Bangladesh Country Office.

Ministry of Health and Family Welfare, Government of the People's Republic of Bangladesh. 2003. "Conceptual Framework of Health, Nutrition and Population Sector Programme 
(HNPSP) July 2003 - June 2006.” Dhaka: Ministry of Health and Family Welfare, Government of the People's Republic of Bangladesh.

. 2002. "Bangladesh Population Policy.” Draft. Dhaka: Ministry of Health and Family

Welfare, Government of the People’s Republic of Bangladesh.

.1998. “Health and Population Sector Programme (HPSP) 1998-2003.” Dhaka: Ministry of Health and Family Welfare, Government of the People's Republic of Bangladesh.

Ministry of Youth and Sports, Government of the People’s Republic of Bangladesh. 2004.

“National Youth Policy.” Dhaka: Ministry of Youth and Sports, Government of the People's Republic of Bangladesh.

Nahar, Q., C. Tunon, I. Houvras, R. Gazi, M. Reza, N.L. Huq, and B. Khudal. 1999.

"Reproductive health needs of adolescents in Bangladesh: A study report.” Working Paper

No. 161. Dhaka, Bangladesh: International Centre for Diarrhoeal Diseases Research, Bangladesh (ICDDR, B), Center for Health and Population Research.

National Institute of Population Research and Training (NIPORT), Mitra and Associates, and Macro International Inc. 2004. "Bangladesh demographic and health survey 2004.” Dhaka, Bangladesh and Calverton, Maryland [USA]: National Institute of Population Research and Training, Mitra and Associates, and Macro International Inc.

National Institute of Population Research and Training (NIPORT) and ORC Macro. 2003. “Bangladesh maternal health services and maternal mortality survey 2001.” Dhaka, Bangladesh and Calverton, Maryland, USA: NIPORT ORC Macro.

Rahman, Laila. 2005. "Findings and Lessons Learned: Scaling up of Reproductive Health Curriculum in Youth Training Courses,” presentation at the Dissemination Seminar of Population Council's FRONTIERS Program and Department of Youth Development, Ministry of Youth and Sports, Government of the People's Republic of Bangladesh, Dhaka 23 March.

Rahman, Laila, Ismat Bhuiya, and Ubaidur Rob. 2003. “Deep Down the Adolescents' Sexual Behavior: Initiations and Implications,” presentation at the Second Asia Pacific Conference on Reproductive and Sexual Health, Bangkok, Thailand, 6-10 October.

Rob, Ubaidur. 2005. "Overview of the Scaling up of Reproductive Health Curriculum in Youth Training Courses Project,” presentation at the Dissemination Seminar of Population Council's FRONTIERS Program and Department of Youth Development, Ministry of Youth and Sports, Government of the People’s Republic of Bangladesh, Dhaka 23 March.

Rob, Ubaidur, Ismat Bhuiya, Laila Rahman, and Nazia Yusuf. 2002. “Improving adolescents' reproductive health in Bangladesh.” FRONTIERS Research Update No. 2. Dhaka: Population Council.

Rob, Ubaidur, and Ismat Bhuiya. 2002. "Reaching Adolescents with Education and Services: Does it Make Difference?” presentation at the American Public Health Association at the 130th Annual Meeting \& Exposition, Philadelphia, USA, 9-13 November.

Rob, Ubaidur. 2002. "Knowledge, Attitude and Behavior of Adolescents towards Reproductive and Sexual Health Issues in Bangladesh,” presentation at the Workshop on Urban 
Adolescents: Knowledge, Attitude and Practice Related to Reproductive Health in Bangladesh, Save the Children (UK), Dhaka, 7-29 July.

Rob, Ubaidur, and Nancy Piet-Pelon. 2001. "Postponing first and second births among young marrieds,” Focus YARH Briefs. Washington D.C.: Pathfinder International.

Rob, Ubaidur, and Ismat Bhuiya. 2001. "Improving adolescents' reproductive health in Bangladesh.” FRONTIERS Research Update No. 1. Dhaka: Population Council.

Rob, Ubaidur, Ismat Bhuiya, and M. E. Khan. 2001. "Risky Sexual Behavior of Adolescents: Implications for HIV/AIDS," presentation at the 129th Annual Meeting and Exposition of American Public Health Association, Atlanta, 21-25 October.

Rob, Ubaidur, and Marium ul Mutahara. 2001. "Premarital sex among urban adolescents in Bangladesh,” in George P. Cernada (ed.), International Quarterly of Community Health Education, Vol. 2 (1). New York: Baywood Publishing Company, Inc., pp. 103-111.

World Health Organization. 2003. "Skills for Health.” WHO Information Series on School Health, Document 9. Geneva: World Health Organization. 


\section{Annex A}

Table A.1 Number of students by sex and training centers

\begin{tabular}{llllllllll}
\hline \multirow{2}{*}{$\begin{array}{l}\text { Training } \\
\text { center }\end{array}$} & Enrolled & \multicolumn{3}{c}{ Drop out } & \multicolumn{3}{c}{ Regular students } \\
\cline { 2 - 10 } & Female & Male & Total & Female & Male & Total & Female & Male & Total \\
\hline Brahmanbaria & 12 & 86 & 98 & - & 5 & 5 & 12 & 81 & 93 \\
Hobigang & 10 & 44 & 54 & 1 & 4 & 5 & 9 & 40 & 49 \\
Kishoreganj & 11 & 87 & 98 & - & 7 & 7 & 11 & 80 & 91 \\
Naogaon & 6 & 94 & 100 & 1 & 6 & 7 & 5 & 88 & 93 \\
Savar & 9 & 182 & 191 & 1 & 20 & 21 & 8 & 162 & 170 \\
Total & $\mathbf{4 8}$ & $\mathbf{4 9 3}$ & $\mathbf{5 4 1}$ & $\mathbf{3}$ & $\mathbf{4 2}$ & $\mathbf{4 5}$ & $\mathbf{4 5}$ & $\mathbf{4 5 1}$ & $\mathbf{4 9 6}$ \\
\hline
\end{tabular}

Table A.2 Number of students who attended reproductive health session by sex and training centers

\begin{tabular}{lllllll}
\hline \multirow{2}{*}{ YTC } & \multicolumn{2}{l}{$\begin{array}{l}\text { Attended } \\
\text { more than five sessions }\end{array}$} & \multicolumn{4}{l}{$\begin{array}{l}\text { Attended } \\
\text { at least one session }\end{array}$} \\
\cline { 2 - 7 } & Female & Male & Total & Female & Male & Total \\
\hline Brahmanbaria & 10 & 59 & 69 & 10 & 62 & 72 \\
Hobiganj & 8 & 21 & 29 & 8 & 32 & 40 \\
Kishoreganj & 9 & 67 & 76 & 9 & 72 & 81 \\
Naogaon & 5 & 77 & 82 & 5 & 85 & 90 \\
Savar & 8 & 148 & 156 & 8 & 154 & 162 \\
Total & $\mathbf{4 0}$ & $\mathbf{3 7 2}$ & $\mathbf{4 1 2}$ & $\mathbf{4 0}$ & $\mathbf{4 0 5}$ & $\mathbf{4 4 5}$ \\
\hline
\end{tabular}


Table A.3 Percent distribution of students' correct reproductive health knowledge by age, sex and time of survey

\begin{tabular}{|c|c|c|c|c|c|c|c|c|c|c|c|c|}
\hline \multirow[t]{2}{*}{ Topics } & \multicolumn{2}{|c|}{ Females } & \multicolumn{2}{|c|}{ Males } & \multicolumn{2}{|l|}{ Total } & \multicolumn{2}{|c|}{$<20$ years } & \multicolumn{2}{|c|}{$20-24$ years } & \multicolumn{2}{|c|}{$>24$ years } \\
\hline & $\begin{array}{l}\text { Pre- } \\
\text { test }\end{array}$ & $\begin{array}{l}\text { Post- } \\
\text { test }\end{array}$ & $\begin{array}{l}\text { Pre- } \\
\text { test }\end{array}$ & $\begin{array}{l}\text { Post- } \\
\text { test }\end{array}$ & $\begin{array}{l}\text { Pre- } \\
\text { test }\end{array}$ & $\begin{array}{l}\text { Post- } \\
\text { test }\end{array}$ & $\begin{array}{l}\text { Pre- } \\
\text { test }\end{array}$ & $\begin{array}{l}\text { Post- } \\
\text { test }\end{array}$ & $\begin{array}{l}\text { Pre- } \\
\text { test }\end{array}$ & $\begin{array}{l}\text { Post- } \\
\text { test }\end{array}$ & $\begin{array}{l}\text { Pre- } \\
\text { test }\end{array}$ & $\begin{array}{l}\text { Post- } \\
\text { test }\end{array}$ \\
\hline \multicolumn{13}{|c|}{ Girls' pubertal changes } \\
\hline Menarche & 92.5 & 92.3 & 71.8 & 95.6 ** & 73.7 & $95.3^{\star *}$ & 72.2 & $93.8^{\star \star}$ & 69.8 & $96.4^{\star *}$ & 80.8 & $94.8^{\star \star}$ \\
\hline $\mathrm{N}$ & 40 & 39 & 390 & 340 & 430 & 379 & 108 & 97 & 192 & 166 & 130 & 116 \\
\hline $\begin{array}{l}\text { Breast } \\
\text { development }\end{array}$ & 79.5 & 89.7 & 83.5 & $96.2^{\star \star}$ & 83.2 & $95.5^{\star \star}$ & 77.6 & $94.8^{\star \star}$ & 80.7 & $97.6^{\star *}$ & 91.5 & 93.1 \\
\hline $\mathrm{N}$ & 39 & 39 & 389 & 340 & 428 & 379 & 107 & 97 & 192 & 166 & 129 & 116 \\
\hline $\begin{array}{l}\text { Growth of } \\
\text { reproductive } \\
\text { organs }\end{array}$ & 56.4 & $94.9 * \star$ & 64.6 & $98.2^{\star \star}$ & 63.9 & $97.9^{\star *}$ & 50.0 & $96.9^{\star \star}$ & 63.9 & $97.6^{\star *}$ & 75.2 & $99.1^{* *}$ \\
\hline $\mathrm{N}$ & 39 & 39 & 390 & 340 & 429 & 379 & 106 & 97 & 194 & 166 & 129 & 116 \\
\hline \multicolumn{13}{|c|}{ Boys' pubertal changes } \\
\hline $\begin{array}{l}\text { Ejaculation/ } \\
\text { wet dreams }\end{array}$ & 67.6 & $97.4^{\star \star}$ & 87.0 & $97.9^{\star \star}$ & 85.3 & $97.9^{\star \star}$ & 83.2 & $100^{\star *}$ & 82.4 & $97.0^{\star *}$ & 91.4 & $97.4^{*}$ \\
\hline $\mathrm{N}$ & 37 & 39 & 391 & 340 & 428 & 379 & 107 & 97 & 193 & 166 & 128 & 116 \\
\hline $\begin{array}{l}\text { Change of } \\
\text { voice }\end{array}$ & 71.8 & $94.9 * \star$ & 80.5 & $97.1^{\star \star}$ & 79.7 & $96.8^{\star *}$ & 71.3 & $95.9^{\star \star}$ & 79.3 & $96.4^{\star \star}$ & 87.5 & $98.3^{* *}$ \\
\hline $\mathrm{N}$ & 39 & 39 & 390 & 340 & 429 & 379 & 108 & 97 & 193 & 166 & 128 & 116 \\
\hline $\begin{array}{l}\text { Growth of } \\
\text { reproductive } \\
\text { organs }\end{array}$ & 50.0 & $97.4^{\star \star}$ & 83.3 & $99.1^{\star \star}$ & 80.4 & $98.9^{\star \star}$ & 71.3 & $99.0^{\star \star}$ & 79.0 & $98.8^{\star \star}$ & 90.0 & $99.1^{* *}$ \\
\hline $\mathrm{N}$ & 38 & 39 & 395 & 340 & 433 & 379 & 108 & 97 & 195 & 166 & 130 & 116 \\
\hline
\end{tabular}

* Significant at $p<0.05 ; * \star p<0.01$. 
Table A.4 Percent distribution of students' correct knowledge of fertile period, modern contraceptive methods, condoms and ECP by age, sex and time of survey

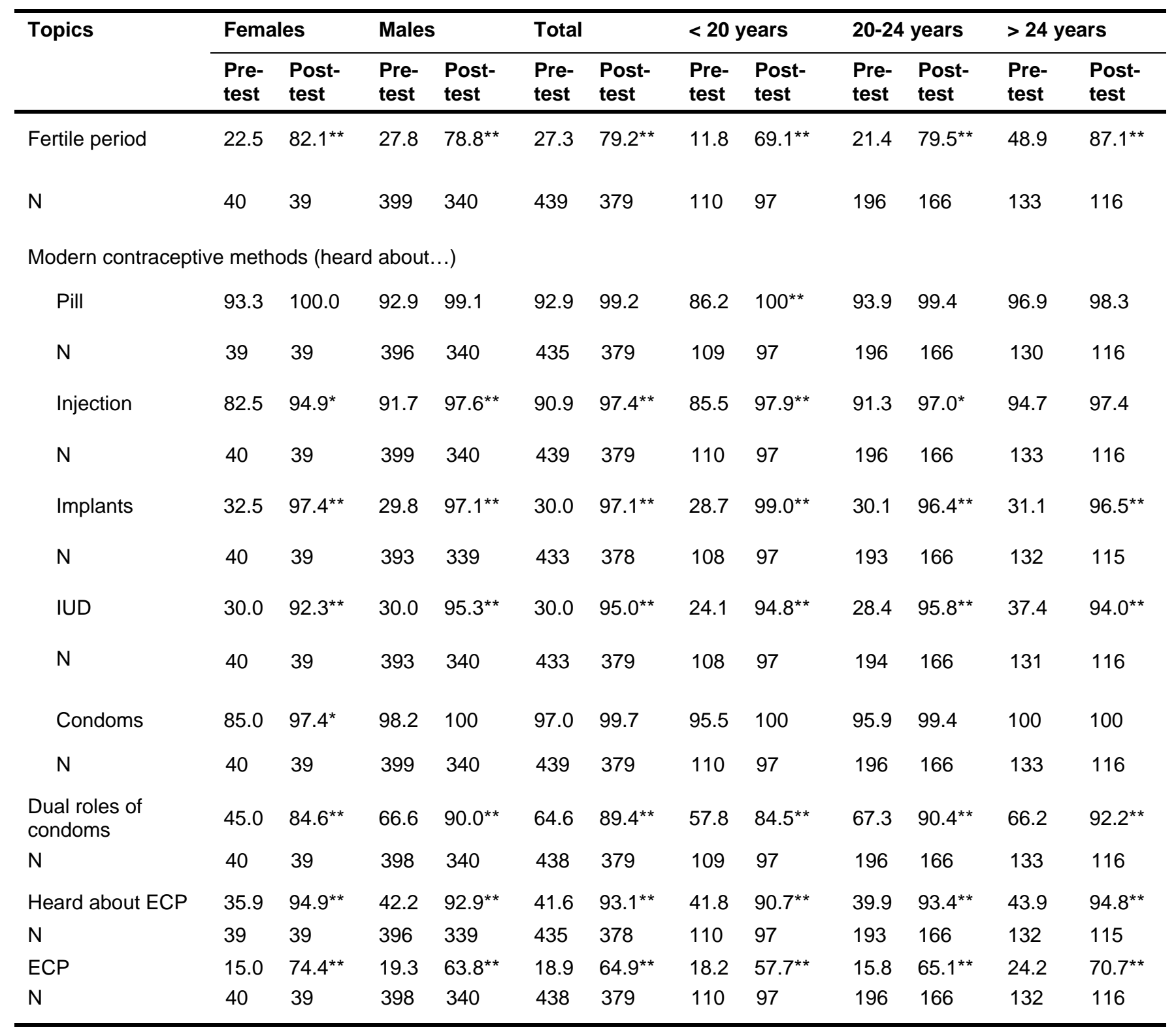

* Significant at $\mathrm{p}<0.05 ; * * \mathrm{p}<0.01$. 
Table A.5 Percent distribution of students' correct knowledge about sex determination of a child and pregnancy-related danger signs by age, sex and time of survey

\begin{tabular}{|c|c|c|c|c|c|c|c|c|c|c|c|c|}
\hline \multirow[t]{2}{*}{ Topics } & \multicolumn{2}{|c|}{ Females } & \multicolumn{2}{|c|}{ Males } & \multicolumn{2}{|l|}{ Total } & \multicolumn{2}{|c|}{$<20$ years } & \multicolumn{2}{|c|}{$20-24$ years } & \multicolumn{2}{|c|}{$>24$ years } \\
\hline & $\begin{array}{l}\text { Pre- } \\
\text { test }\end{array}$ & $\begin{array}{l}\text { Post- } \\
\text { test }\end{array}$ & $\begin{array}{l}\text { Pre- } \\
\text { test }\end{array}$ & $\begin{array}{l}\text { Post- } \\
\text { test }\end{array}$ & $\begin{array}{l}\text { Pre- } \\
\text { test }\end{array}$ & $\begin{array}{l}\text { Post- } \\
\text { test }\end{array}$ & $\begin{array}{l}\text { Pre- } \\
\text { test }\end{array}$ & $\begin{array}{l}\text { Post- } \\
\text { test }\end{array}$ & $\begin{array}{l}\text { Pre- } \\
\text { test }\end{array}$ & $\begin{array}{l}\text { Post- } \\
\text { test }\end{array}$ & $\begin{array}{l}\text { Pre- } \\
\text { test }\end{array}$ & $\begin{array}{l}\text { Post- } \\
\text { test }\end{array}$ \\
\hline $\begin{array}{l}\text { Sex determinant } \\
\text { (chromosome of } \\
\text { a father or only } \\
\text { father determines } \\
\text { sex of a child) }\end{array}$ & 35.9 & $71.8^{\star \star}$ & 25.2 & $76.5^{\star \star}$ & 26.1 & $76.0^{\star \star}$ & 25.9 & $78.4^{\star \star}$ & 26.0 & $74.7^{\star \star}$ & 26.5 & 75.9 ** \\
\hline $\mathrm{N}$ & 39 & 39 & 397 & 340 & 436 & 379 & 108 & 97 & 196 & 166 & 132 & 116 \\
\hline \multicolumn{13}{|c|}{ Pregnancy-related danger signs } \\
\hline $\begin{array}{l}\text { Prolonged labor } \\
\text { for more than } 12 \\
\text { hours }\end{array}$ & 65.0 & $94.9 * *$ & 76.1 & $95.9 * \star$ & 75.1 & $95.8^{\star \star}$ & 65.5 & $96.9^{* *}$ & 71.9 & $93.4^{\star \star}$ & 87.8 & $98.3^{* *}$ \\
\hline $\mathrm{N}$ & 40 & 39 & 397 & 339 & 437 & 378 & 110 & 96 & 196 & 166 & 131 & 116 \\
\hline $\begin{array}{l}\text { High fever and } \\
\text { headache }\end{array}$ & 55.6 & $92.3^{\star \star}$ & 64.4 & $96.7^{\star \star}$ & 63.6 & $96.3^{\star \star}$ & 56.7 & $95.8^{\star \star}$ & 62.8 & $95.2^{\star \star}$ & 70.4 & $98.3^{\star *}$ \\
\hline $\mathrm{N}$ & 36 & 39 & 376 & 338 & 412 & 377 & 104 & 96 & 183 & 166 & 125 & 115 \\
\hline $\begin{array}{l}\text { Headache and } \\
\text { blurry vision }\end{array}$ & 61.1 & $97.4^{\star \star}$ & 68.8 & $95.0^{\star \star}$ & 68.2 & $95.2^{\star \star}$ & 64.4 & $95.8^{\star *}$ & 68.3 & $94.0^{\star \star}$ & 71.1 & $96.5^{\star \star}$ \\
\hline $\mathrm{N}$ & 36 & 39 & 385 & 338 & 421 & 377 & 104 & 96 & 189 & 166 & 128 & 115 \\
\hline $\begin{array}{l}\text { Excessive } \\
\text { bleeding }\end{array}$ & 63.9 & $87.2^{\star \star}$ & 64.3 & $90.2^{\star \star}$ & 64.3 & $89.9^{\star *}$ & 57.3 & $91.7^{\star \star}$ & 59.1 & $90.4^{\star \star}$ & 77.6 & $87.8^{\star \star}$ \\
\hline $\mathrm{N}$ & 36 & 39 & 378 & 338 & 414 & 377 & 103 & 96 & 186 & 166 & 125 & 115 \\
\hline Convulsion & 68.6 & $97.4^{\star \star}$ & 63.5 & $94.1^{*}$ & 63.9 & $94.4^{\star \star}$ & 51.9 & $93.8^{\star \star}$ & 60.4 & $93.4^{\star \star}$ & 79.5 & $96.5^{\star \star}$ \\
\hline $\mathrm{N}$ & 35 & 39 & 378 & 338 & 413 & 377 & 104 & 96 & 187 & 166 & 122 & 115 \\
\hline
\end{tabular}

* Significant at $\mathrm{p}<0.05 ; * * \mathrm{p}<0.01$. 
Table A.6 Percent distribution of students' correct knowledge of transmission of STIs by age, sex and time of survey

\begin{tabular}{|c|c|c|c|c|c|c|c|c|c|c|c|c|}
\hline \multirow[t]{2}{*}{ Topics } & \multicolumn{2}{|c|}{ Females } & \multicolumn{2}{|c|}{ Males } & \multicolumn{2}{|l|}{ Total } & \multicolumn{2}{|c|}{$<20$ years } & \multicolumn{2}{|c|}{$20-24$ years } & \multicolumn{2}{|c|}{$>24$ years } \\
\hline & $\begin{array}{l}\text { Pre- } \\
\text { test }\end{array}$ & $\begin{array}{l}\text { Post- } \\
\text { test }\end{array}$ & $\begin{array}{l}\text { Pre- } \\
\text { test }\end{array}$ & $\begin{array}{l}\text { Post- } \\
\text { test }\end{array}$ & $\begin{array}{l}\text { Pre- } \\
\text { test }\end{array}$ & $\begin{array}{l}\text { Post- } \\
\text { test }\end{array}$ & $\begin{array}{l}\text { Pre- } \\
\text { test }\end{array}$ & $\begin{array}{l}\text { Post- } \\
\text { test }\end{array}$ & $\begin{array}{l}\text { Pre- } \\
\text { test }\end{array}$ & $\begin{array}{l}\text { Post- } \\
\text { test }\end{array}$ & $\begin{array}{l}\text { Pre- } \\
\text { test }\end{array}$ & $\begin{array}{l}\text { Post- } \\
\text { test }\end{array}$ \\
\hline \multicolumn{13}{|c|}{ Routes of transmission of STIs } \\
\hline $\begin{array}{l}\text { Unprotected } \\
\text { sex without } \\
\text { condoms }\end{array}$ & 62.5 & $89.7^{\star \star}$ & 82.7 & $96.2^{\star \star}$ & 80.8 & $95.5^{\star \star}$ & 75.2 & $94.8^{\star \star}$ & 81.0 & $95.8^{\star \star}$ & 85.3 & $95.7^{\star * *}$ \\
\hline $\mathrm{N}$ & 40 & 39 & 393 & 340 & 433 & 379 & 109 & 97 & 195 & 166 & 129 & 116 \\
\hline $\begin{array}{l}\text { Unsterilized } \\
\text { blood } \\
\text { transfusion }\end{array}$ & 51.3 & $84.6^{\star *}$ & 78.7 & $93.8^{\star \star}$ & 76.2 & $92.9 * *$ & 69.7 & $93.8^{\star *}$ & 74.3 & $91.0^{\star \star}$ & 84.4 & $94.8^{\star *}$ \\
\hline $\mathrm{N}$ & 39 & 39 & 389 & 340 & 428 & 379 & 109 & 97 & 191 & 166 & 128 & 116 \\
\hline $\begin{array}{l}\text { Sharing } \\
\text { needles }\end{array}$ & 75.0 & 74.4 & 80.9 & $89.4^{\star \star}$ & 80.3 & $87.9 * *$ & 76.1 & $87.6^{\star}$ & 80.9 & $88.0^{*}$ & 82.9 & 87.9 \\
\hline $\mathrm{N}$ & 40 & 39 & 392 & 340 & 432 & 379 & 109 & 97 & 194 & 166 & 129 & 116 \\
\hline Mother to child & 40.5 & 59.0 & 64.1 & $84.1^{\text {** }}$ & 62.1 & $81.5^{\star \star}$ & 54.2 & $78.4^{\star \star}$ & 61.1 & $81.3^{\star \star}$ & 70.1 & $84.5^{\star \star}$ \\
\hline $\mathrm{N}$ & 37 & 39 & 390 & 340 & 427 & 379 & 107 & 97 & 193 & 166 & 127 & 116 \\
\hline \multicolumn{13}{|c|}{ Routes of non-transmission of STIs } \\
\hline $\begin{array}{l}\text { Sharing soap } \\
\text { or toilet }\end{array}$ & 42.5 & $84.6^{\star \star}$ & 43.8 & $92.1^{\star \star}$ & 43.7 & $91.3^{\star *}$ & 34.9 & $89.7^{\star *}$ & 44.3 & $89.8^{\star \star}$ & 50.4 & $94.8^{\star *}$ \\
\hline $\mathrm{N}$ & 40 & 39 & 388 & 340 & 428 & 379 & 109 & 97 & 192 & 166 & 127 & 116 \\
\hline Sharing clothes & 42.1 & $64.1^{*}$ & 34.0 & $80.9 * \star$ & 34.7 & $79.2^{\star \star}$ & 34.6 & $76.3^{\star *}$ & 35.4 & $78.3^{\star \star}$ & 33.9 & $82.8^{\star *}$ \\
\hline $\mathrm{N}$ & 38 & 39 & 388 & 340 & 426 & 379 & 107 & 97 & 192 & 166 & 127 & 116 \\
\hline $\begin{array}{l}\text { Sweating and } \\
\text { saliva }\end{array}$ & 31.6 & $74.4^{\star \star}$ & 26.0 & $75.0^{\star \star}$ & 26.5 & $74.9 * *$ & 17.6 & $72.2^{\star \star}$ & 27.7 & $79.5^{\star \star}$ & 32.0 & $70.7^{\star * *}$ \\
\hline $\mathrm{N}$ & 38 & 39 & 389 & 340 & 427 & 379 & 108 & 97 & 191 & 166 & 128 & 116 \\
\hline
\end{tabular}

* Significant at $p<0.05 ;{ }^{* *} p<0.01$. 
Table A.7 Percent distribution of students' correct knowledge of what to do to treat STIs by age, sex and time of survey

\begin{tabular}{|c|c|c|c|c|c|c|c|c|c|c|c|c|}
\hline \multirow[t]{2}{*}{ Topics } & \multicolumn{2}{|c|}{ Females } & \multicolumn{2}{|c|}{ Males } & \multicolumn{2}{|l|}{ Total } & \multicolumn{2}{|c|}{$<20$ years } & \multicolumn{2}{|c|}{ 20-24 years } & \multicolumn{2}{|c|}{$>24$ years } \\
\hline & $\begin{array}{l}\text { Pre- } \\
\text { test }\end{array}$ & $\begin{array}{l}\text { Post- } \\
\text { test }\end{array}$ & $\begin{array}{l}\text { Pre- } \\
\text { test }\end{array}$ & $\begin{array}{l}\text { Post- } \\
\text { test }\end{array}$ & $\begin{array}{l}\text { Pre- } \\
\text { test }\end{array}$ & $\begin{array}{l}\text { Post- } \\
\text { test }\end{array}$ & $\begin{array}{l}\text { Pre- } \\
\text { test }\end{array}$ & $\begin{array}{l}\text { Post- } \\
\text { test }\end{array}$ & $\begin{array}{l}\text { Pre- } \\
\text { test }\end{array}$ & $\begin{array}{l}\text { Post- } \\
\text { test }\end{array}$ & $\begin{array}{l}\text { Pre- } \\
\text { test }\end{array}$ & $\begin{array}{l}\text { Post- } \\
\text { test }\end{array}$ \\
\hline \multicolumn{13}{|c|}{ What to do to treat STIs } \\
\hline $\begin{array}{l}\text { Seek treatment } \\
\text { from a qualified } \\
\text { doctor }\end{array}$ & 71.8 & $97.4^{\star \star}$ & 87.7 & $97.1^{\star \star}$ & 86.3 & $97.1^{\star \star}$ & 84.5 & $95.9 * \star$ & 80.9 & $98.2^{\star \star}$ & 96.0 & 96.6 \\
\hline $\mathrm{N}$ & 39 & 39 & 391 & 340 & 430 & 379 & 110 & 97 & 194 & 166 & 126 & 116 \\
\hline $\begin{array}{l}\text { Strictly follow } \\
\text { instructions of } \\
\text { the doctor }\end{array}$ & 62.5 & $92.3^{\star *}$ & 90.5 & $98.2^{\star \star}$ & 87.9 & $97.6^{\star \star}$ & 88.1 & 96.9 ** & 86.0 & $97.6^{\star \star}$ & 90.7 & $98.3^{\star *}$ \\
\hline $\mathrm{N}$ & 40 & 39 & 391 & 340 & 431 & 379 & 109 & 97 & 193 & 166 & 129 & 116 \\
\hline $\begin{array}{l}\text { Visit doctor } \\
\text { with the sexual } \\
\text { partner }\end{array}$ & 62.5 & $94.9^{\star \star}$ & 74.3 & $97.4^{\star \star}$ & 73.2 & $97.1^{\star \star}$ & 68.8 & $93.8^{\star \star}$ & 70.1 & $100^{\star \star}$ & 81.5 & $95.7^{\star \star}$ \\
\hline $\mathrm{N}$ & 40 & 39 & 393 & 340 & 433 & 379 & 109 & 97 & 194 & 166 & 130 & 116 \\
\hline \multicolumn{13}{|c|}{ What not to do to treat STIs } \\
\hline $\begin{array}{l}\text { Consult with } \\
\text { the canvasser }\end{array}$ & 25.0 & $71.8^{\star \star}$ & 59.3 & $88.5^{\star \star}$ & 56.1 & $86.8^{\star \star}$ & 41.3 & $77.3^{\star \star}$ & 54.4 & $90.4^{\star *}$ & 71.8 & $89.7^{\text {** }}$ \\
\hline $\mathrm{N}$ & 40 & 39 & 386 & 340 & 426 & 379 & 109 & 97 & 193 & 166 & 124 & 116 \\
\hline $\begin{array}{l}\text { Stop taking } \\
\text { medicine as } \\
\text { soon as the } \\
\text { symptoms } \\
\text { disappear }\end{array}$ & 23.1 & $71.8^{\star \star}$ & 39.3 & $80.9 * *$ & 37.8 & $79.9^{\star *}$ & 35.8 & $76.3^{\star \star}$ & 38.4 & $83.1^{\star \star}$ & 38.7 & $78.4^{\star \star}$ \\
\hline $\mathrm{N}$ & 39 & 39 & 384 & 340 & 423 & 379 & 109 & 97 & 190 & 166 & 124 & 116 \\
\hline
\end{tabular}

* Significant at $p<0.05 ; * \star p<0.01$. 
Table A.8 Percent distribution of students' correct knowledge about prevention of HIV by age, sex and time of survey

\begin{tabular}{|c|c|c|c|c|c|c|c|c|c|c|c|c|}
\hline \multirow[t]{2}{*}{ Topics } & \multicolumn{2}{|c|}{ Females } & \multicolumn{2}{|c|}{ Males } & \multicolumn{2}{|l|}{ Total } & \multicolumn{2}{|c|}{$<20$ years } & \multicolumn{2}{|c|}{$20-24$ years } & \multicolumn{2}{|c|}{$>24$ years } \\
\hline & $\begin{array}{l}\text { Pre- } \\
\text { test }\end{array}$ & $\begin{array}{l}\text { Post- } \\
\text { test }\end{array}$ & $\begin{array}{l}\text { Pre- } \\
\text { test }\end{array}$ & $\begin{array}{l}\text { Post- } \\
\text { test }\end{array}$ & $\begin{array}{l}\text { Pre- } \\
\text { test }\end{array}$ & $\begin{array}{l}\text { Post- } \\
\text { test }\end{array}$ & $\begin{array}{l}\text { Pre- } \\
\text { test }\end{array}$ & $\begin{array}{l}\text { Post- } \\
\text { test }\end{array}$ & $\begin{array}{l}\text { Pre- } \\
\text { test }\end{array}$ & $\begin{array}{l}\text { Post- } \\
\text { test }\end{array}$ & $\begin{array}{l}\text { Pre- } \\
\text { test }\end{array}$ & $\begin{array}{l}\text { Post- } \\
\text { test }\end{array}$ \\
\hline Abstinence & 32.5 & $59.0 * \star$ & 52.3 & $67.1^{\text {** }}$ & 50.5 & $66.2^{\star \star}$ & 56.9 & $69.1^{\star \star}$ & 48.7 & $66.9 * \star$ & 47.7 & 62.9 ** \\
\hline $\mathrm{N}$ & 40 & 39 & 388 & 340 & 428 & 379 & 109 & 97 & 191 & 166 & 128 & 116 \\
\hline $\begin{array}{l}\text { Limit sexual } \\
\text { contact with only } \\
\text { one uninfected } \\
\text { partner }\end{array}$ & 35.0 & 76.9 ** & 60.2 & $86.2^{\star \star}$ & 57.8 & $85.2^{\star \star}$ & 55.0 & $82.5^{\star \star}$ & 54.4 & $87.3^{\star \star}$ & 65.4 & $84.5^{\star \star}$ \\
\hline $\mathrm{N}$ & 40 & 39 & 389 & 340 & 429 & 379 & 109 & 97 & 193 & 166 & 127 & 116 \\
\hline Use of condoms & 60.0 & $89.7^{\star *}$ & 83.8 & $96.5^{\star \star}$ & 81.6 & $95.8^{\star \star}$ & 80.9 & $94.8^{\star *}$ & 80.7 & $97.6^{\star \star}$ & 83.6 & $94.0^{\star *}$ \\
\hline $\mathrm{N}$ & 40 & 39 & 390 & 340 & 430 & 379 & 110 & 97 & 192 & 166 & 128 & 116 \\
\hline $\begin{array}{l}\text { Safe blood } \\
\text { transfusion }\end{array}$ & 53.8 & $97.4^{\star \star}$ & 75.7 & $93.5^{\star \star}$ & 73.7 & $93.9^{\star *}$ & 76.1 & $93.8^{\star \star}$ & 69.1 & $94.6^{\star \star}$ & 78.4 & $93.1^{\star \star}$ \\
\hline $\mathrm{N}$ & 39 & 39 & 383 & 340 & 422 & 379 & 109 & 97 & 188 & 166 & 125 & 116 \\
\hline $\begin{array}{l}\text { Use of sterilized } \\
\text { syringe }\end{array}$ & 59.0 & $82.1^{*}$ & 74.7 & $89.7^{\star \star}$ & 73.3 & $88.9^{\star \star}$ & 75.9 & $88.7^{\star \star}$ & 68.9 & $88.6^{\star \star}$ & 77.6 & $89.7^{* \star}$ \\
\hline $\mathrm{N}$ & 39 & 39 & 384 & 340 & 423 & 379 & 108 & 97 & 190 & 166 & 125 & 116 \\
\hline $\begin{array}{l}\text { Negotiate safe } \\
\text { sex with partner }\end{array}$ & 33.3 & $79.5^{\star \star}$ & 54.8 & $82.9^{\star \star}$ & 52.8 & $82.6^{\star \star}$ & 54.1 & $79.4^{\star \star}$ & 47.2 & $81.3^{\star \star}$ & 60.3 & $87.1^{\star \star}$ \\
\hline $\mathrm{N}$ & 39 & 39 & 389 & 340 & 428 & 379 & 109 & 97 & 193 & 166 & 126 & 116 \\
\hline
\end{tabular}

* Significant at $p<0.05 ;{ }^{* *} p<0.01$. 
Table A.9 Percent distribution of students' positive attitude towards wet dreams, masturbation, and menstruation by age, sex and time of survey

\begin{tabular}{|c|c|c|c|c|c|c|c|c|c|c|c|c|}
\hline \multirow[t]{2}{*}{ Topics } & \multicolumn{2}{|c|}{ Females } & \multicolumn{2}{|c|}{ Males } & \multicolumn{2}{|l|}{ Total } & \multicolumn{2}{|c|}{$<20$ years } & \multicolumn{2}{|c|}{$20-24$ years } & \multicolumn{2}{|c|}{$>24$ years } \\
\hline & $\begin{array}{l}\text { Pre- } \\
\text { test }\end{array}$ & $\begin{array}{l}\text { Post- } \\
\text { test }\end{array}$ & $\begin{array}{l}\text { Pre- } \\
\text { test }\end{array}$ & $\begin{array}{l}\text { Post- } \\
\text { test }\end{array}$ & $\begin{array}{l}\text { Pre- } \\
\text { test }\end{array}$ & $\begin{array}{l}\text { Post- } \\
\text { test }\end{array}$ & $\begin{array}{l}\text { Pre- } \\
\text { test }\end{array}$ & $\begin{array}{l}\text { Post- } \\
\text { test }\end{array}$ & $\begin{array}{l}\text { Pre- } \\
\text { test }\end{array}$ & $\begin{array}{l}\text { Post- } \\
\text { test }\end{array}$ & $\begin{array}{l}\text { Pre- } \\
\text { test }\end{array}$ & $\begin{array}{l}\text { Post- } \\
\text { test }\end{array}$ \\
\hline $\begin{array}{l}\text { Agreed that it is } \\
\text { natural for boys to } \\
\text { have wet dreams }\end{array}$ & 50.0 & $92.3^{\star *}$ & 84.9 & $96.2^{\star \star}$ & 81.9 & $95.8^{\star *}$ & 75.2 & $94.8^{\star *}$ & 82.9 & $98.2^{\star \star}$ & 85.6 & $93.1^{*}$ \\
\hline $\mathrm{N}$ & 38 & 39 & 392 & 340 & 430 & 379 & 105 & 97 & 193 & 166 & 132 & 116 \\
\hline $\begin{array}{l}\text { Agreed that } \\
\text { masturbation is } \\
\text { not a bad habit }\end{array}$ & 15.2 & $33.3^{*}$ & 10.4 & $24.4^{\star \star}$ & 10.8 & $25.3^{\star *}$ & 11.8 & $34.0^{\star \star}$ & 11.1 & $21.1^{\star \star}$ & 9.5 & $24.1^{\star \star}$ \\
\hline $\mathrm{N}$ & 33 & 39 & 385 & 340 & 418 & 379 & 102 & 97 & 190 & 166 & 126 & 116 \\
\hline $\begin{array}{l}\text { Agreed that } \\
\text { menstruation is } \\
\text { not a disease }\end{array}$ & 51.4 & $87.2^{\star \star}$ & 58.0 & $93.2^{* *}$ & 57.5 & $92.6^{\star *}$ & 46.2 & $93.8^{\star \star}$ & 54.8 & $90.4^{\star *}$ & 70.6 & $94.8^{\star \star}$ \\
\hline $\mathrm{N}$ & 37 & 39 & 379 & 340 & 416 & 379 & 104 & 97 & 186 & 166 & 126 & 116 \\
\hline $\begin{array}{l}\text { Agreed that } \\
\text { menstrual cloths } \\
\text { should be dried in } \\
\text { direct sunlight }\end{array}$ & 60.5 & $92.3^{\star \star}$ & 30.4 & $93.8^{\star *}$ & 33.2 & $93.7^{\star *}$ & 31.1 & $93.8^{\star \star}$ & 32.3 & $94.6^{\star \star}$ & 36.2 & $92.2^{\star \star}$ \\
\hline $\mathrm{N}$ & 38 & 39 & 381 & 340 & 419 & 379 & 103 & 97 & 189 & 166 & 127 & 116 \\
\hline
\end{tabular}

* Significant at $p<0.05 ;{ }^{* *} p<0.01$

Table A.10 Percent distribution of students' attitude towards use of condoms and family planning methods by age, sex and time of survey

\begin{tabular}{|c|c|c|c|c|c|c|c|c|c|c|c|c|}
\hline \multirow[t]{2}{*}{ Topics } & \multicolumn{2}{|c|}{ Females } & \multicolumn{2}{|c|}{ Males } & \multicolumn{2}{|l|}{ Total } & \multicolumn{2}{|c|}{$<20$ years } & \multicolumn{2}{|c|}{$20-24$ years } & \multicolumn{2}{|c|}{$>24$ years } \\
\hline & $\begin{array}{l}\text { Pre- } \\
\text { test }\end{array}$ & $\begin{array}{l}\text { Post- } \\
\text { test }\end{array}$ & $\begin{array}{l}\text { Pre- } \\
\text { test }\end{array}$ & $\begin{array}{l}\text { Post- } \\
\text { test }\end{array}$ & $\begin{array}{l}\text { Pre- } \\
\text { test }\end{array}$ & $\begin{array}{l}\text { Post- } \\
\text { test }\end{array}$ & $\begin{array}{l}\text { Pre- } \\
\text { test }\end{array}$ & $\begin{array}{l}\text { Post- } \\
\text { test }\end{array}$ & $\begin{array}{l}\text { Pre- } \\
\text { test }\end{array}$ & $\begin{array}{l}\text { Post- } \\
\text { test }\end{array}$ & $\begin{array}{l}\text { Pre- } \\
\text { test }\end{array}$ & $\begin{array}{l}\text { Post- } \\
\text { test }\end{array}$ \\
\hline $\begin{array}{l}\text { Agreed that } \\
\text { sexually active } \\
\text { young persons } \\
\text { should use } \\
\text { condoms to } \\
\text { prevent STIs and } \\
\text { HIV }\end{array}$ & 63.2 & $84.6^{*}$ & 91.7 & $95.6^{*}$ & 89.2 & $94.5^{\star \star}$ & 83.5 & $93.8^{\star}$ & 91.3 & 94.0 & 90.8 & 95.7 \\
\hline $\mathrm{N}$ & 38 & 39 & 397 & 340 & 435 & 379 & 109 & 97 & 196 & 166 & 130 & 116 \\
\hline $\begin{array}{l}\text { Agreed that } \\
\text { sexually active } \\
\text { young persons } \\
\text { should FP } \\
\text { methods to } \\
\text { prevent pregnancy }\end{array}$ & 56.8 & $82.1^{\star \star}$ & 69.1 & $84.1^{\star \star}$ & 68.1 & $83.9^{\star \star}$ & 70.1 & $83.5^{\star}$ & 64.1 & $85.5^{\star \star}$ & 72.3 & $81.9 *$ \\
\hline $\mathrm{N}$ & 37 & 39 & 395 & 340 & 432 & 379 & 107 & 97 & 195 & 166 & 130 & 116 \\
\hline
\end{tabular}


Table A.11 Percent distribution of students who stated what to do in case an elderly person touches a young person inappropriately by sex and time of survey

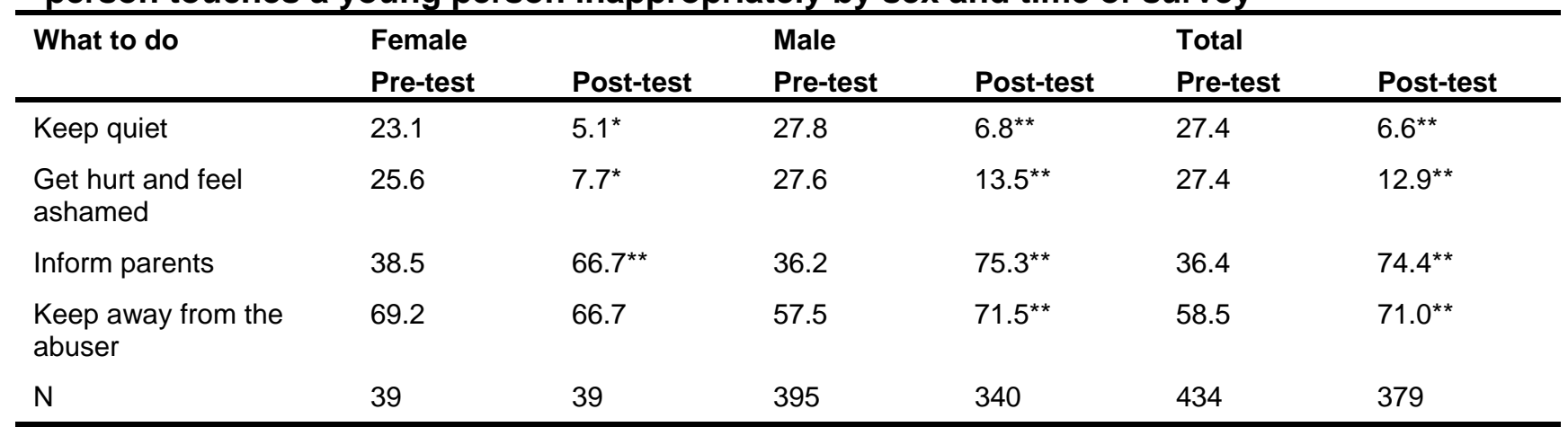

* Significant at $p<0.05 ;{ }^{* \star} p<0.01$. Multiple responses.

Table A.12 Percent distribution of students who stated what to do in case a boyfriend wants to initiate sex by time of surveys and sex

\begin{tabular}{lllllll}
\hline What to do & $\begin{array}{l}\text { Female } \\
\text { Pre-test }\end{array}$ & Post-test & $\begin{array}{l}\text { Male } \\
\text { Pre-test }\end{array}$ & Post-test & $\begin{array}{l}\text { Total } \\
\text { Pre-test }\end{array}$ & Post-test \\
\hline $\begin{array}{l}\text { Agree in fear of } \\
\text { desertion }\end{array}$ & 2.6 & 5.1 & 11.5 & $4.1^{\star \star}$ & 10.7 & $4.2^{\star \star}$ \\
$\begin{array}{l}\text { Agree in condition of } \\
\text { using condoms }\end{array}$ & 7.9 & 5.1 & 38.6 & $24.1^{\star \star}$ & 35.9 & $22.2^{\star \star}$ \\
$\begin{array}{l}\text { Request to wait until } \\
\text { marriage }\end{array}$ & 44.7 & $76.9^{\star *}$ & 59.3 & $85.3^{\star \star}$ & 58.0 & $84.4^{\star *}$ \\
$\begin{array}{l}\text { End the relationship } \\
\mathrm{N}\end{array}$ & $\begin{array}{l}21.1 \\
38\end{array}$ & 23.1 & 9.5 & $15.0^{*}$ & 10.5 & $15.8^{*}$ \\
\hline
\end{tabular}

* Significant at $p<0.05 ;{ }^{* \star} p<0.01$. Multiple responses. 
Table A.13 Percent distribution of students' critical thinking skills to avert media influence and peer pressure by age, sex and time of survey

\begin{tabular}{|c|c|c|c|c|c|c|c|c|c|c|c|c|}
\hline \multirow[t]{2}{*}{ Topics } & \multicolumn{2}{|c|}{ Females } & \multicolumn{2}{|c|}{ Males } & \multicolumn{2}{|l|}{ Total } & \multicolumn{2}{|c|}{$<20$ years } & \multicolumn{2}{|c|}{$20-24$ years } & \multicolumn{2}{|c|}{$>24$ years } \\
\hline & $\begin{array}{l}\text { Pre- } \\
\text { test }\end{array}$ & $\begin{array}{l}\text { Post- } \\
\text { test }\end{array}$ & $\begin{array}{l}\text { Pre- } \\
\text { test }\end{array}$ & $\begin{array}{l}\text { Post- } \\
\text { test }\end{array}$ & $\begin{array}{l}\text { Pre- } \\
\text { test }\end{array}$ & $\begin{array}{l}\text { Post- } \\
\text { test }\end{array}$ & $\begin{array}{l}\text { Pre- } \\
\text { test }\end{array}$ & $\begin{array}{l}\text { Post- } \\
\text { test }\end{array}$ & $\begin{array}{l}\text { Pre- } \\
\text { test }\end{array}$ & $\begin{array}{l}\text { Post- } \\
\text { test }\end{array}$ & $\begin{array}{l}\text { Pre- } \\
\text { test }\end{array}$ & $\begin{array}{l}\text { Post- } \\
\text { test }\end{array}$ \\
\hline $\begin{array}{l}\text { Agreed that one } \\
\text { should not smoke } \\
\text { like a favorite actor }\end{array}$ & 80.0 & 92.3 & 88.7 & $97.1^{\star *}$ & 87.9 & $96.6^{\star *}$ & 86.4 & $95.9^{\star \star}$ & 85.6 & $97.0^{\star \star}$ & 92.4 & 96.6 \\
\hline $\mathrm{N}$ & 40 & 39 & 397 & 340 & 437 & 379 & 110 & 97 & 195 & 166 & 132 & 116 \\
\hline $\begin{array}{l}\text { Agreed not to } \\
\text { accept free drugs } \\
\text { from friends }\end{array}$ & 63.2 & $89.7^{* *}$ & 76.6 & $92.9 * \star$ & 75.4 & $92.6^{\star *}$ & 76.6 & $90.7^{\star \star *}$ & 75.8 & $92.2^{\star \star}$ & 73.8 & $94.8^{\star \star}$ \\
\hline $\mathrm{N}$ & 38 & 39 & 389 & 340 & 427 & 379 & 107 & 97 & 190 & 166 & 130 & 116 \\
\hline $\begin{array}{l}\text { Agreed not to } \\
\text { accompany a } \\
\text { friend in visiting } \\
\text { commercial sex } \\
\text { workers }\end{array}$ & 72.5 & $89.7^{*}$ & 73.8 & $95.9 * *$ & 73.7 & $95.3^{\star \star}$ & 69.1 & $92.8^{\star \star}$ & 73.2 & $95.8^{\star \star}$ & 78.5 & $96.6^{\star *}$ \\
\hline $\mathrm{N}$ & 40 & 39 & 390 & 340 & 430 & 379 & 110 & 97 & 190 & 166 & 130 & 116 \\
\hline
\end{tabular}

* Significant at $p<0.05 ;{ }^{* *} p<0.01$

Table A.14 Percent distribution of students' attitude towards reproductive health education by age, sex and time of survey

\begin{tabular}{|c|c|c|c|c|c|c|c|c|c|c|c|c|}
\hline \multirow[t]{2}{*}{ Topics } & \multicolumn{2}{|c|}{ Females } & \multicolumn{2}{|c|}{ Males } & \multicolumn{2}{|l|}{ Total } & \multicolumn{2}{|c|}{$<20$ years } & \multicolumn{2}{|c|}{$20-24$ years } & \multicolumn{2}{|c|}{$>24$ years } \\
\hline & $\begin{array}{l}\text { Pre- } \\
\text { test }\end{array}$ & $\begin{array}{l}\text { Post- } \\
\text { test }\end{array}$ & $\begin{array}{l}\text { Pre- } \\
\text { test }\end{array}$ & $\begin{array}{l}\text { Post- } \\
\text { test }\end{array}$ & $\begin{array}{l}\text { Pre- } \\
\text { test }\end{array}$ & $\begin{array}{l}\text { Post- } \\
\text { test }\end{array}$ & $\begin{array}{l}\text { Pre- } \\
\text { test }\end{array}$ & $\begin{array}{l}\text { Post- } \\
\text { test }\end{array}$ & $\begin{array}{l}\text { Pre- } \\
\text { test }\end{array}$ & $\begin{array}{l}\text { Post- } \\
\text { test }\end{array}$ & $\begin{array}{l}\text { Pre- } \\
\text { test }\end{array}$ & $\begin{array}{l}\text { Post- } \\
\text { test }\end{array}$ \\
\hline $\begin{array}{l}\text { Supported } \\
\text { reproductive } \\
\text { health education }\end{array}$ & 80.6 & $97.4^{\star \star}$ & 91.9 & $96.8^{\star \star}$ & 90.9 & $96.8^{\star \star}$ & 86.9 & $94.8^{\star}$ & 92.8 & $97.6^{*}$ & 91.4 & $97.4^{*}$ \\
\hline $\mathrm{N}$ & 36 & 39 & 394 & 340 & 430 & 379 & 107 & 97 & 195 & 166 & 128 & 116 \\
\hline $\begin{array}{l}\text { Agreed to } \\
\text { advocate for } \\
\text { reproductive } \\
\text { health education }\end{array}$ & 78.4 & $97.4^{\star \star}$ & 84.9 & $99.1^{\star *}$ & 84.3 & $98.9^{\star \star}$ & 72.9 & $99.0^{\star \star}$ & 85.9 & $98.8^{\star *}$ & 91.4 & $99.1^{\text {** }}$ \\
\hline $\mathrm{N}$ & 37 & 39 & 390 & 340 & 427 & 379 & 107 & 97 & 192 & 166 & 128 & 116 \\
\hline
\end{tabular}

* Significant at $p<0.05 ;$ ** $p<0.01$. 
Table A.15 Average mark obtained by teachers in imparting reproductive health education in the practice sessions of training of trainers by teachers

\begin{tabular}{|c|c|c|c|c|c|c|c|c|c|c|c|}
\hline \multirow[b]{2}{*}{ Criteria } & \multirow[b]{2}{*}{ Mark } & \multicolumn{10}{|c|}{ Teacher ID } \\
\hline & & 1 & 2 & 3 & 4 & 5 & 6 & 7 & 8 & 9 & 10 \\
\hline \multicolumn{12}{|c|}{ Average number received in the practice sessions } \\
\hline Facilitation skill* & 40 & 27 & 31 & 27 & 26 & 30 & 27 & 31 & 28 & 32 & 27 \\
\hline $\begin{array}{l}\text { Clear concept/ } \\
\text { knowledge }\end{array}$ & 10 & 8 & 8 & 6 & 7 & 7 & 7 & 7 & 7 & 8 & 8 \\
\hline $\begin{array}{l}\text { Friendliness and } \\
\text { non-judgmental } \\
\text { attitude }\end{array}$ & 10 & 7 & 9 & 7 & 7 & 7 & 7 & 7 & 7 & 8 & 7 \\
\hline $\begin{array}{l}\text { Incorporating } \\
\text { participants in } \\
\text { discussion }\end{array}$ & 10 & 7 & 8 & 7 & 7 & 8 & 7 & 8 & 7 & 7 & 7 \\
\hline $\begin{array}{l}\text { Use of training } \\
\text { materials }\end{array}$ & 5 & 4 & 4 & 4 & 4 & 4 & 4 & 4 & 4 & 4 & 4 \\
\hline $\begin{array}{l}\text { Selection and } \\
\text { conduction of } \\
\text { training methods }\end{array}$ & 5 & 4 & 4 & 4 & 3 & 4 & 4 & 4 & 4 & 4 & 4 \\
\hline $\begin{array}{l}\text { Use of proper } \\
\text { language }\end{array}$ & 5 & 3 & 4 & 4 & 3 & 3 & 3 & 4 & 4 & 4 & 4 \\
\hline $\begin{array}{l}\text { Proper eye-contact } \\
\text { and body language }\end{array}$ & 5 & 3 & 4 & 3 & 3 & 4 & 3 & 3 & 3 & 3 & 4 \\
\hline Time management & 5 & 5 & 4 & 4 & 3 & 4 & 4 & 4 & 3 & 4 & 3 \\
\hline Confidence & 5 & 4 & 5 & 3 & 3 & 4 & 4 & 4 & 3 & 4 & 4 \\
\hline Total & 100 & 71 & 80 & 69 & 66 & 74 & 69 & 75 & 71 & 78 & 70 \\
\hline
\end{tabular}

* Facilitation skill included adeptly following five specific steps: conducting introduction, clearly mentioning of the objectives of the session, presentation of the contents, taking feedback from the participants and summarization.

Table A.16 Percent distribution of students who stated specific capacities of teachers in imparting reproductive health education by sex and time of survey

\begin{tabular}{llll}
\hline Criteria & \multicolumn{3}{l}{ Immediate post-test } \\
\cline { 2 - 4 } & Female & Male & Total \\
\hline Sufficient knowledge & 88.9 & 94.9 & 94.3 \\
Could explain clearly & 91.7 & 94.3 & 94.1 \\
Non-judgmental and friendly & 91.7 & 86.0 & 86.6 \\
Mentioned about role of condoms for & 97.2 & 97.7 & 97.7 \\
preventing STIs and HIV & & & 387 \\
$\mathrm{~N}$ & 36 & 351 & 38 \\
\hline
\end{tabular}




\section{Annex B: Lesson Plan of the TOT}

\begin{tabular}{|c|c|c|c|c|c|c|c|c|c|}
\hline & $10.00-10.15$ & \multirow{2}{*}{\multicolumn{2}{|c|}{$\begin{array}{l}\text { 10.15-10.30 } \\
\text { Overview of the } \\
\text { Project: Ubaidur } \\
\text { Rob, Country } \\
\text { Director, PC }\end{array}$}} & $10.30-10.45$ & $10.45-11.00$ & $11.00-11.15$ & $11.15-11.45$ & $10.45-12.00$ & $1145-1215$ \\
\hline & $\begin{array}{l}\text { Inauguration: } \\
\text { S.M. Waliur } \\
\text { Rahman, DG, } \\
\text { Department of } \\
\text { Youth Development }\end{array}$ & & & $\begin{array}{l}\text { Objectives of TOT: } \\
\text { Director, Training, } \\
\text { Department of } \\
\text { Youth } \\
\text { Development and } \\
\text { Project Director, } \\
\text { PC }\end{array}$ & $\begin{array}{l}\text { Ground rules of } \\
\text { TOT: Deputy } \\
\text { Director, Training, } \\
\text { Department of } \\
\text { Youth } \\
\text { Development }\end{array}$ & Tea break & $\begin{array}{l}\text { Introduction } \\
\text { and ice } \\
\text { breaking }\end{array}$ & $\begin{array}{l}\text { Expectations and } \\
\text { barriers }\end{array}$ & $\begin{array}{l}\text { Pre-course } \\
\text { evaluation }\end{array}$ \\
\hline & $12.15-1.00$ & \multicolumn{2}{|l|}{$1.00-1.45$} & \multirow{2}{*}{$\begin{array}{l}1.45-2.45 \\
\text { Changes during } \\
\text { adolescence }\end{array}$} & $2.45-3.15$ & $3.15-3.30$ & $3.30-4.30$ & $4.30-5.40$ & $5.40-5.45$ \\
\hline & $\begin{array}{l}\text { Advocacy for life } \\
\text { skill reproductive } \\
\text { health and HIVI } \\
\text { AIDS education } \\
\end{array}$ & \multicolumn{2}{|l|}{ Lunch } & & $\begin{array}{l}\text { Values, friendship, } \\
\text { family relation, life } \\
\text { skills }\end{array}$ & Tea break & $\begin{array}{l}\text { Gender } \\
\text { concept }\end{array}$ & $\begin{array}{l}\text { Marriage, sexual } \\
\text { relation, and abuse }\end{array}$ & Review \\
\hline \multirow{4}{*}{ 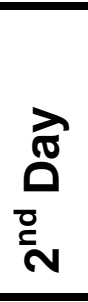 } & $10.00-10.15$ & \multicolumn{2}{|l|}{$10.15-10.30$} & $10.30-11.35$ & $11.35-11.50$ & $11.50-1.20$ & $1.20-2.00$ & $2.00-3.00$ & $3.00-4.00$ \\
\hline & Energizer & \multicolumn{2}{|l|}{ Review } & RTI/STIS & Tea break & HIV and AIDS & Lunch & Family planning & $\begin{array}{l}\text { Safe } \\
\text { motherhood }\end{array}$ \\
\hline & $4.00-4.15$ & \multicolumn{2}{|l|}{$4.15-5.00$} & $5.00-5.30$ & \multicolumn{2}{|l|}{$5.30-5.45$} & & & \\
\hline & Tea break & \multicolumn{2}{|c|}{ Substance abuse } & Facilitation skills & \multicolumn{2}{|c|}{$\begin{array}{l}\text { Distribution of practice sessions and } \\
\text { review of the day }\end{array}$} & & & \\
\hline \multirow{4}{*}{ 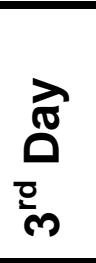 } & $10.00-10.15$ & \multicolumn{2}{|l|}{$10.15-10.30$} & $10.30-11.30$ & $11.30-12.00$ & $12.00-1.00$ & $1.00-1.45$ & $1.45-2.45$ & 2.45-3.00 \\
\hline & Energizer & \multicolumn{2}{|l|}{ Review } & Practice session: 1 & Tea break & Practice session: 2 & Lunch & Practice session: 3 & Tea break \\
\hline & $3.00-4.00$ & \multicolumn{3}{|l|}{$4.00-5.00$} & & & & & \\
\hline & Practice session: 4 & \multicolumn{3}{|c|}{ Practice session: 5} & & & & & \\
\hline \multirow{4}{*}{ 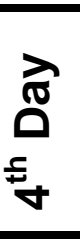 } & $10.00-10.15$ & \multicolumn{2}{|l|}{$10.15-10.30$} & $10.30-11.30$ & $11.30-12.00$ & $12.00-1.00$ & $1.00-1.45$ & $1.45-2.45$ & $2.45-3.00$ \\
\hline & Energizer & \multicolumn{3}{|r|}{ Practice session: 6} & Tea break & Practice session: 7 & Lunch & Practice session: 8 & Tea break \\
\hline & $3.00-4.00$ & \multicolumn{3}{|l|}{$4.00-5.00$} & & & & & \\
\hline & Practice session: 9 & \multicolumn{3}{|c|}{ Practice session: 10} & & & & & \\
\hline \multirow[b]{2}{*}{ 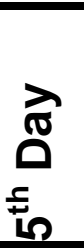 } & $10.00-10.30$ & $\begin{array}{l}10.30- \\
11.00\end{array}$ & $\begin{array}{l}11.00- \\
11.15\end{array}$ & $11.15-12.00$ & $12.00-12.15$ & $12.15-12.30$ & \multicolumn{2}{|l|}{$12.30-1.15$} & $1.15-2.00$ \\
\hline & $\begin{array}{l}\text { Energizer and } \\
\text { review }\end{array}$ & $\begin{array}{l}\text { Post- } \\
\text { course } \\
\text { evaluation }\end{array}$ & Tea break & $\begin{array}{l}\text { Development } \\
\text { of plan }\end{array}$ & $\begin{array}{l}\text { Implementation } \\
\text { plan } \\
\text { presentation }\end{array}$ & $\begin{array}{l}\text { Distribution of } \\
\text { certificates }\end{array}$ & \multicolumn{2}{|c|}{$\begin{array}{l}\text { Closing remarks: Country Director, } \\
\text { Population Council, } \\
\text { Directors and Director General, } \\
\text { Department of Youth Development }\end{array}$} & $\begin{array}{l}\text { End of TOT } \\
\text { with Lunch }\end{array}$ \\
\hline
\end{tabular}




\section{Annex C: Facilitation Observation Checklist}

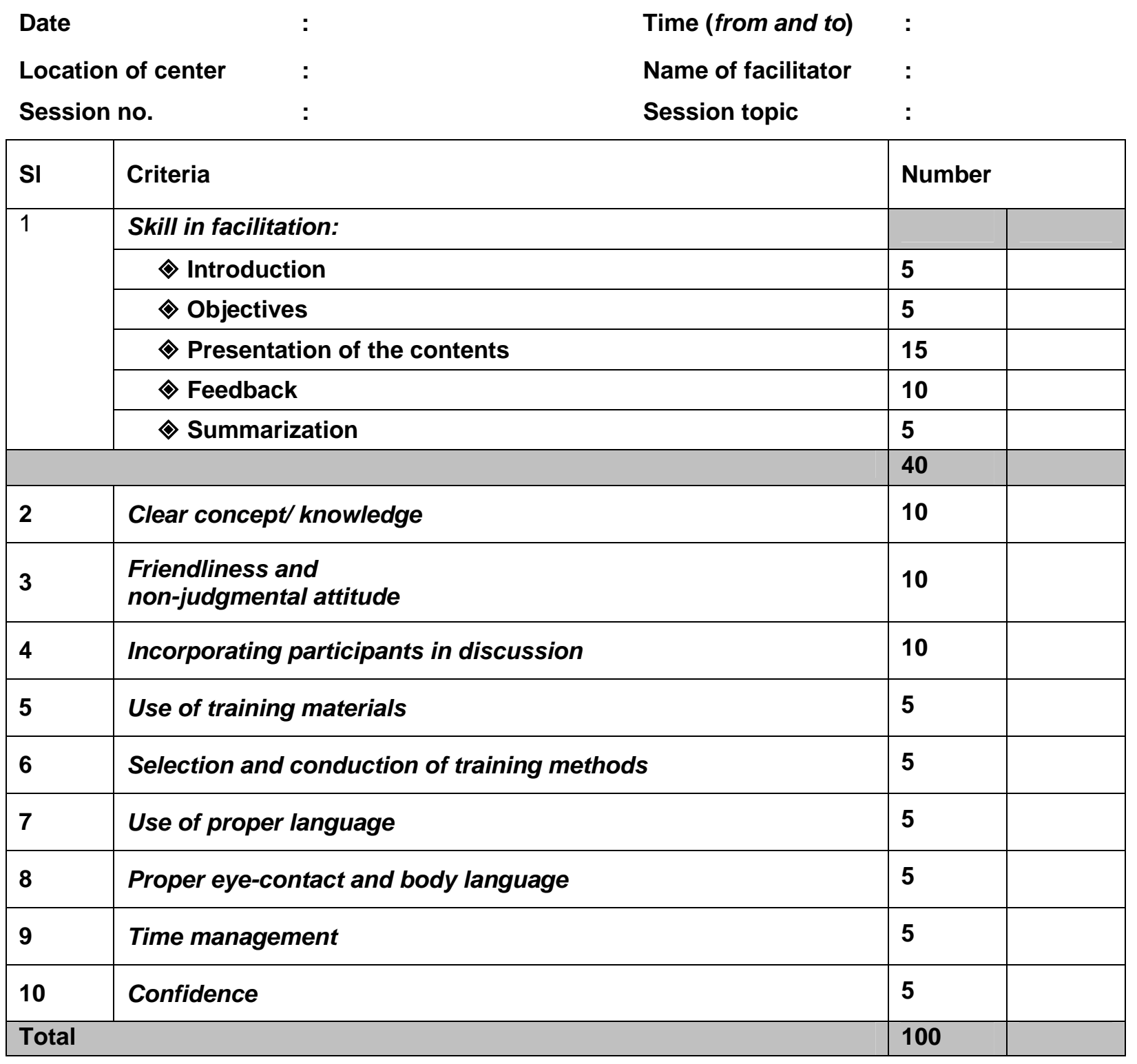

\begin{tabular}{|l|l|}
\hline Strengths of the facilitator & Weaknesses of the facilitator \\
\hline & \\
& \\
\hline
\end{tabular}




\title{
Annex D: Request Letter to Provide Technical Assistance in Department of Youth Development Training Institutions
}

\author{
Government of the People's Repuplic of Bangladesh \\ Office of the Director General \\ Department of Youth Development \\ Ministry of Youth \& Sports \\ 108, Motijheel C/A, Dhaka.
}

Memo No-DYD/New YTC/Mise-17/96 (Part)-35/8, Date7-こ-0 こ.

Subject: Technical Assistance for Strengthening Reproductive Health, HIV/AIDS Programmes of DYD.

This may kindly be noted that in collaboration with Department of Youth Development and Population Council organized a Research work on Life SkillBased Re-productive health, HIV/AIDS and Gender curriculum in five residential Youth Training Centres at Savar, Noagoan, Hobigonj, Kishorgonj and B-Baria. The Research findings are highly appreciated by the Department of Youth Development. On the basis of Research findings we have decided to extend similar programme in our different training centres for strengthening Life Skill-Based Re-productive health, HIV/AIDS and Gender curriculum.

Therefore, we request Population Council for extending assistance in all residential and non-residential training centres of DYD for strengthening the above mentioned progremme.

Thanking you for your continued support and co-operation.

With best regards,

To,

Mr. Obaidur Rob

Country Director

Population Council

House No -CES (B)-21

Road No -118, Gulshan, Dhaka.

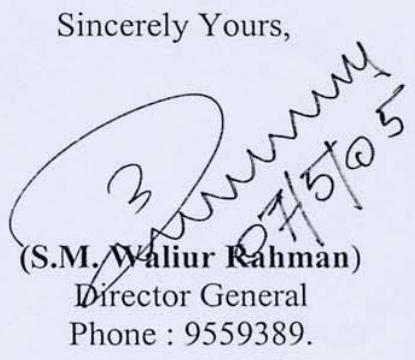

